JEFFREY D. SACHS

Harvard University

ANDREW WARNER

Harvard University

\title{
Economic Reform and the Process of Global Integration
}

When the brookings Panel on Economic Activity began in 1970, the world economy roughly accorded with the idea of three distinct economic systems: a capitalist first world, a socialist second world, and a developing third world which aimed for a middle way between the first two. The third world was characterized not only by its low levels of per capita GDP, but also by a distinctive economic system that assigned the state sector the predominant role in industrialization, although not the monopoly on industrial ownership as in the socialist economies.

The years between 1970 and 1995, and especially the last decade, have witnessed the most remarkable institutional harmonization and economic integration among nations in world history. While economic integration was increasing throughout the 1970s and 1980s, the extent of integration has come sharply into focus only since the collapse of communism in 1989. In 1995 one dominant global economic system is emerging. The common set of institutions is exemplified by the new World Trade Organization (WTO), which was established by agreement of more than 120 economies, with almost all the rest eager to join as rapidly as possible. Part of the new trade agreement involves a codification of basic principles governing trade in goods and services. Similarly, the International Monetary Fund (IMF) now boasts nearly universal membership, with member countries pledged to basic principles of currency convertibility.

Most programs of economic reform now underway in the developing world and in the post-communist world have as their strategic aim the 
integration of the national economy with the world economy. Integration means not only increased market-based trade and financial flows, but also institutional harmonization with regard to trade policy, legal codes, tax systems, ownership patterns, and other regulatory arrangements. In each of these areas, international norms play a large and often decisive role in defining the terms of the reform policy. Most recently, China made commitments on international property rights and trade policy with a view toward membership in the WTO, and membership in the world system more generally. Russian economic reforms are similarly guided by the overall aim of reestablishing the country's place within the world market system. In several sections of its April 1995 agreement with the IMF, the Russian government commits to abide by WTO principles, even in advance of membership.

The goal of this paper is to document the process of global integration and to assess its effects on economic growth in the reforming countries. Using cross-country indicators of trade openness as the measures of each country's orientation to the world economy, we examine the timing of trade liberalization, and the implications of trade liberalization for subsequent growth and for the onset or avoidance of economic crises. Of course, trade liberalization is usually just one part of a government's overall reform plan for integrating an economy with the world system. Other aspects of such a program almost always include price liberalization, budget restructuring, privatization, deregulation, and the installation of a social safety net. Nonetheless, the international opening of the economy is the sine qua non of the overall reform process. Trade liberalization not only establishes powerful direct linkages between the economy and the world system, but also effectively forces the government to take actions on the other parts of the reform program under the pressures of international competition. For these reasons, it is convenient and fairly accurate to gauge a country's overall reform program according to the progress of its trade liberalization.

Our analysis helps to answer several debates concerning cross-country growth patterns. Most important, we help to resolve the widely discussed conundrum concerning economic convergence in the world economy. Long-held judgments about the development process, as well as the workhorse formal models of economic growth, suggest that poorer countries should tend to grow more rapidly than richer countries and therefore should close the proportionate income gap over time. The 
main reason for expecting economic convergence is that the poorer countries can import capital and modern technologies from the wealthier countries, and thereby reap the "advantages of backwardness." Yet in recent decades, there has been no overall tendency for the poorer countries to catch up, or converge, with the richer countries.

We show that this problem is readily explained by the trade regime: open economies tend to converge, but closed economies do not. The lack of convergence in recent decades results from the fact that the poorer countries have been closed to the world. This is now changing with the spread of trade liberalization programs, so that presumably the tendencies toward convergence will be markedly strengthened. The power of trade to promote economic convergence is perhaps the most venerable tenet of classical and neoclassical economics, dating back to Adam Smith. As Smith's followers have stressed for generations, trade promotes growth through a myriad channels: increased specialization, efficient resource allocation according to comparative advantage, diffusion of international knowledge through trade, and heightened domestic competition as a result of international competition. ${ }^{1}$

This paper has three main parts. In the first section we discuss the patterns and chronology of trade policy reforms in the postwar period. Viewed from the perspective of world economic history since 1850, the closed nature of the world trading system at the end of World War II was a historical anomaly. The open trade of the late nineteenth and early twentieth centuries had collapsed following two world wars and a global depression. Postwar liberalization has painstakingly restored an open trading system somewhat reminiscent of the world in 1900, with two crucial differences. First, developing countries in Africa and Asia are now sovereign, rather than colonies of the Western powers. Second, the world economy is increasingly supported by international commercial law agreed to by individual governments and implemented with the support of international institutions such as the WTO and the IMF.

1. Lucas (1988) and Young (1991) observe that standard trade theory predicts an effect of openness on the level, not the long-run growth rate, of GDP. Of course, a level effect can appear as a growth effect for long periods of time, since adjustments in real economies may take place over decades. Some recent theory has introduced various forms of increasing returns to scale with the result that openness can affect long-term growth as well as the level of income. See Young (1991), Grossman and Helpman (1991), Eicher (1993), and Lee (1993). 
The second section examines the impact of postwar trade liberalization on economic performance in the developing countries. We demonstrate the basic proposition that open trade leads to convergent rates of growth, that is, to higher growth rates in poorer countries than in richer countries. The importance of trade policy is demonstrated in several cross-country growth equations in which we hold constant other determinants of growth. We also show that open economies successfully avoid balance-of-payments crises, while many closed economies eventually succumb to such crises.

The third section reviews the evidence on the success of trade liberalization programs after 1980. First, we show that in many developing countries trade liberalization has followed a severe macroeconomic crisis (such as a debt crisis or very high inflation). A very few developing countries have remained relatively open since World War II or since the time of their independence-Barbados, Cyprus, Malaysia, Mauritius, Singapore, Thailand, and the Yemen Arab Republic (North Yemen)but most of the others opened much later, mainly in the 1980s or 1990s, and usually in response to a deep macroeconomic crisis. ${ }^{2}$ In many cases, economic reform paid off after a few years in terms of accelerated growth of GDP. This is true in all major regions of the world, including sub-Saharan Africa. In a small number of countries, however, a new economic crisis ensued after the start of full-fledged reforms. These setbacks, in Chile in the early 1980s, Venezuela in the early 1990s, and Mexico in late 1994, seem to be related to financial market liberalization and exchange rate mismanagement. ${ }^{3}$

We also present evidence on the growth effects of reforms in the postcommunist countries of eastern Europe and the former Soviet Union. Here too we find evidence that economic reforms lead to a renewal of economic growth. Strong reformers seem to outperform weak reformers both in terms of a smaller decline of GDP between 1990 and 1994, and in terms of an earlier resumption of economic growth. The evidence is necessarily fragmentary, however, given the very short period for in which the reforms have been in operation.

2. Some developing countries, such as Peru, Sri Lanka, and several Central American countries, were rather open at the end of World War II, but then moved into a prolonged phase of import substitution in the 1950s and 1960s.

3. See Sachs, Tornell, and Velasco (1995) and Warner (1994) regarding the Mexican crisis. 


\section{Liberalization and Global Integration before 1970}

One and one-half centuries ago, two close observers of the capitalist revolution in Western Europe made a pithy prediction about the course of global economic change. Marx and Engels correctly sensed the unprecedented efficiency of the industrial capitalism that had emerged. They predicted that as a result of superior economic efficiency, capitalism would eventually sweep through the entire world, compelling other societies to restructure along the lines of Western Europe. In the pungent rhetoric of the Communist Manifesto they expostulated that:

The bourgeoisie, by the rapid improvement of all instruments of production, by the immensely facilitated means of communication, draws all, even the most barbarian, nations into civilization. The cheap prices of its commodities are the heavy artillery with which it batters down all Chinese walls, with which it forces the barbarians' intensely obstinate hatred of foreigners to capitulate. It compels all nations, on pain of extinction, to adopt the bourgeois mode of production; it compels them to introduce what it calls civilization into their midst, i.e., to become bourgeois themselves. In one word, it creates a world after its own image. ${ }^{4}$

Marx and Engels got much disastrously wrong in their predictions, but they correctly sensed the decisive global implications of capitalism. As they foresaw, capitalism eventually spread to nearly the entire world, in a complex and sometimes violent process that dramatically raised worldwide living standards but also provoked social upheaval and war. It is often forgotten today, in the flush of the communist collapse after 1989, that global capitalism has emerged twice, at the end of the nineteenth century as well as the end of the twentieth century. The earlier global capitalist system peaked around 1910 but subsequently disintegrated in the first half of the twentieth century, between the outbreak of World War I and the end of World War II. The reemergence of a global, capitalist market economy since 1950 , and especially since the mid-1980s, in an important sense reestablishes the global market economy that had existed one hundred years earlier.

The first episode of global capitalism, of course, came about as much through the instruments of violent conquest and colonial rule as through economic reform and the development of international institutions. Starting around 1840, Western European powers wielded their superior

4. Marx and Engels (1948, p. 225). 
industrial—and hence military - power to challenge traditional societies around the world. France began to colonize North Africa in the 1830s and 1840s; Britain forced its way into China in the Opium Wars, 1839-42; Britain and France defeated Russia in the Crimean War, 1854-56; and Britain completed the conquest of India in 1857. Among the populous societies of Asia and Near East, only Japan was able to mobilize social and political institutions to support market reforms, implementing history's first "shock therapy" reforms following the 1868 Meiji Restoration. ${ }^{5}$

By the 1870s a global market had begun to take shape on the following economic lines. Western Europe and the United States constituted the main industrial powers. A major push toward industrialization, especially in east-central Europe, followed the unification of Germany. Russia began a period of rapid industrialization, partly through the building of foreign-financed railways across Russian Eurasia. Japan had begun its dramatic opening to the world economy through the adoption of capitalist institutions and free trade. (Note that early Japanese industrialization took place entirely under free trade, since the dominant Western powers imposed low Japanese tariff levels through "unequal treaties" that lasted until the end of the century.) Latin America, after a half century of postindependence upheaval, finally settled into market-based, export-led growth in the 1870 s, based on raw materials exports and capital imports (primarily for railroad construction). Africa, which lagged farthest behind, was gobbled up by the Western European powers in an orgy of imperial competition that reached its height between 1880 and 1910. Trade barriers remained low among these economies for several decades, from the 1860 s to $1914 .^{6}$

5. See Jansen and Rozman (1988) for a detailed analysis of the economic, political, and social reforms of the Meiji period.

6. The era of nineteenth-century free trade is usually dated from 1846, when Britain unilaterally liberalized by repealing the Corn Laws. (In fact, liberalization had begun earlier, with the abolition of export duties in 1842 and the reduction of import duties in 1842 and 1845.) The next decisive step was the Cobden-Chevalier Treaty of 1860 , which liberalized British-French trade. The new German Reich was established by Bismarck on free trade principles and low tariffs in the early 1870s. It is often suggested that this free trade era ended in 1879 with a renewed wave of protectionism, starting with Bismarck's acceptance of the famous tariff of bread and iron, which raised imports duties on agriculture and steel. Higher tariffs soon followed in France and Italy. In fact, even with these tariff increases, average tariff rates remained low until World War I, and nontariff barriers (for example, quotas and exchange controls) were virtually nonexistent. According to data assembled by Capie $(1983$, table 1.3, p. 8$)$, average tariff revenues as a percentage of total 
As in the late twentieth century, the emergence of the first global system was based on the interaction of technology and economic institutions. Long-distance transport and communications achieved breakthroughs similar to those in the present. ${ }^{7}$ The Suez Canal, completed in 1869 , and the Panama Canal, completed in 1914, dramatically cut international shipping times, as did the progressive development of faster and larger steamships from the 1840s. New railways in India, Russia, the United States, and Latin America-often built with foreign financeopened vast, fertile territories for settlement and economic development. The spread of telegraph lines and transoceanic cables from the 1850 s linked the world at electronic speed. Military innovations, particularly the breech-loading rifle in the 1840 s, combined with mass-production made possible by industrialization, decisively shifted the military advantage to Europe. Medical advances, particularly the use of quinine as a preventative against malaria, played a pivotal role in the spread of European settlements, domination, and investment, especially in Africa. Without doubt, these technological breakthroughs were as revolutionary in underpinning the emerging global system as those of our own age.

On the economic level, key institutions similarly spread on a global scale. International gold and silver standards became nearly universal after the 1870s, eventually embracing North and South America, Europe, Russia, Japan, China, as well as other European colonies and independent countries. By 1908 roughly 89 percent of the world's population lived in countries with convertible currencies under the gold or silver standard. ${ }^{8}$ Basic legal institutions, such as business and commercial

imports stayed below 10 percent in France, Germany, and the United Kingdom; between 10 and 20 percent in Italy; between 20 and 30 percent in the United States; and between 20 and 40 percent in Russia.

7. See Headrick (1981).

8. See Eichengreen and Flandreau (1994, p. 9). The countries on the gold or silver standards in 1908 include, in Europe: United Kingdom, France, Belgium, Switzerland, Italy, Germany, Netherlands, Portugal, and Romania; in North America: United States and Canada; in Central America: Mexico, Nicaragua, Guatemala, Honduras, Salvador, and Costa Rica; in South America: Peru, Chile, Brazil, Venezuela, and Argentina; in Asia and the Pacific: India, China, Indonesia, Japan, Siam, Philippines, and Australia; and in the Middle East: the Ottoman Empire, Egypt, and Persia. The national currencies were convertible into gold in all cases except the following: Italy, Austria, Spain, Portugal, Nicaragua, Guatemala, Peru, Chile, Brazil, and Venezuela. The Italian and Austrian currencies were stable though not convertible. 
codes, were widely adopted. These were based on European models, mainly the Napoleonic Code. New multilateral institutions were established, such as the Universal Postal Union in 1878.

The system was highly integrative, as in the present. A network of bilateral trade treaties kept protectionism in check in most countries (the United States and Russia, where tariff rates were relatively high, being the exceptions). Nations as diverse as Argentina and Russia struggled to adjust their economic policies, and especially their financial policies, to attract foreign investment, particularly for railway building. The adoption of a stable currency tied to gold was seen as a key step in the strategy of international integration. In Russia, Count Witte recalled how he outmaneuvered the conservative tsarist çourt to introduce the gold standard at the end of the nineteenth century. ${ }^{9}$ In Latin America, liberal market regimes stabilized under both democratic (Argentina and Chile) and authoritarian (Brazil and Mexico) political regimes. In all four cases, overall growth of GDP and exports was very rapid, indeed historically unprecedented. India similarly enjoyed rapid export growth between 1870 and 1914, under British rule.

In a series of important papers, Jeffrey Williamson and his collaborators have shown that the open international system at the end of the nineteenth century produced an era of economic convergence.$^{10}$ Peripheral countries in Europe, such as Ireland and the Scandinavian countries, experienced rapid growth that narrowed the gap in real wages with the more advanced countries, the United Kingdom, France, and Germany. Former European colonies in Latin America and the South Pacific (Australia and New Zealand) similarly achieved convergent growth rates based on export-led growth.

In a massive study of long-term growth in forty-one developing countries, Lloyd Reynolds similarly finds that the open international economy of 1850-1914 was crucial in promoting the onset of rapid economic growth in much of the developing world outside of Europe and North America. ${ }^{11}$ Reynolds notes that "politics apart, the main factor determining the timing of turning points has been a country's ability to participate effectively in the trade opportunities opened by expansion of the world economy." ${ }^{12} \mathrm{He}$ then points out the wide range of countries that

\footnotetext{
9. See Owen (1994, pp. 15-16).

10. See Williamson $(1992,1993)$ and O'Rourke and Williamson (1994).

11. Reynolds (1985).

12. Reynolds (1985).
} 
were indeed able to avail themselves of the burgeoning trade opportunities, including almost all of Latin America (with the exception of Venezuela); much of Asia, including but not limited to Ceylon, Burma, Malaya, Thailand, Japan, Taiwan, and the Philippines; and parts of Africa, including Algeria, Nigeria, Ghana, the Ivory Coast, Kenya, Uganda, Tanganyika, and Southern Rhodesia. ${ }^{13}$

Surely the most famous evocation of this remarkable international setting is given by Keynes in the opening pages of The Economic Consequences of the Peace:

What an extraordinary episode in the economic progress of man that age was which came to an end in August 1914! . . . The inhabitant of London could order by telephone, sipping his morning tea in bed, the various products of the whole earth, in such quantity as he might see fit, and reasonably expect their early delivery upon his doorstep; he could at the same moment and by the same means adventure his wealth in the natural resources and new enterprises of any quarter of the world, and share, without exertion or even trouble, in their prospective fruits and advantages; or he could decide to couple the security of his fortunes with the good faith of the townspeople of any substantial municipality in any continent that fancy or information might recommend. He could secure forthwith, if he wished it, cheap and comfortable means of transit to any country or climate without passport or other formality, could despatch his servant to the neighbouring office of a bank for such supply of the precious metals as might seem convenient, and could then proceed abroad to foreign quarters, without knowledge of their religion, language, or customs, bearing coined wealth upon his person, and would consider himself greatly aggrieved and much surprised at the least interference. But, most important of all, he regarded this state of affairs as normal, certain, and permanent, except in the direction of further improvement, and any deviation from it as aberrant, scandalous, and avoidable. ${ }^{14}$

Keynes rightly intuited in 1919 that the Humpty Dumpty of world markets and shared institutions would not soon be put back together in the harsh peace that followed World War I. Indeed, the war and its aftermath laid waste to the emergent global capitalist system for more than half a century. The financial underpinnings of the late-nineteenth-century liberal order were not reestablished. British dominance in the international financial system was ended by the Great War, and neither U.S. leadership nor international cooperation took its place. ${ }^{15}$ Financial instability and the failure of the gold standard rocked the 1920s and contributed to the Great Depression of the 1930s. The export-led growth of

13. Reynolds (1985, pp. 34-35).

14. Keynes (1919, pp. 6-7).

15. See Kindleberger (1973) and Eichengreen (1993). 
the primary producers in Latin America and elsewhere was undermined by low and unstable commodities prices in the 1920s, and then was devastated by the Great Depression, which brought the utter collapse of the terms of trade, intense protectionism in Europe and the United States, and the end of capital inflows.

Political upheaval accompanied economic and military upheaval. Most important was the Bolshevik Revolution in Russia in 1917, and the emergence of fascist states in Italy and Germany in the 1920s and 1930s respectively. In Latin America, the traditional political power of the landholders and mine owners was undermined by the collapse in the terms of trade. The free trade regimes of the late nineteenth century were replaced by a revolutionary regime in Mexico and authoritarian regimes in Argentina, Brazil, and Chile, that were heavily influenced by the state planning of the communist and fascist regimes in the Soviet Union and Europe. ${ }^{16}$ Throughout the world, state planning, authoritarianism, and militarism competed with limited government and marketbased economies. Whether or not economic theory offered insights and predictions about these alternative strategies, political leaders felt compelled to push for new and radical experimentation.

The changing zeitgeist is again decisively captured by Keynes, in his remarkable lecture "National Self-Sufficiency" delivered in Ireland in 1933, when the world was in the depths of the Great Depression. ${ }^{17}$ In the lecture, Keynes rejects the commitment to free trade and the international harmonization of institutions, declaring the late-nineteenthcentury experience a massive, and apparently inevitable, failure. In Keynes's view, the international system led to war, by stoking the competition among the leading powers:

The protection of a country's existing foreign interests, the capture of new markets, the progress of economic imperialism - these are a scarcely avoidable part of a scheme of things which aims at the maximum of international specialisation and at the maximum geographical diffusion of capital wherever its seat of ownership. ${ }^{18}$

For this reason, countries are best linked by ideas and culture, not economic and financial entanglements. Keynes writes:

I sympathise, therefore, with those who would minimise, rather than with those who would maximise, economic entanglements between nations. Ideas, knowl-

16. See Thorp (1984) for very insightful essays on the country-by-country experience.

17. Keynes (1933).

18. Keynes (1933, p. 236). 
edge, art, hospitality, travel-these are the things which should of their nature be international. But let goods be homespun whenever it is reasonably and conveniently possible; and, above all, let finance be primarily national. ${ }^{19}$

But perhaps more to the point, Keynes stressed, was the fact that countries simply demanded the right to experiment with new economic models, since the old ones no longer commanded respect and assent. He joined the chorus for experimentation, vividly exemplifying the end of intellectual faith in global capitalism by the 1930s:

The point is that there is no prospect for the next generation of a uniformity of economic systems throughout the world, such as existed, broadly speaking, during the nineteenth century; that we all need to be as free as possible of interference from economic changes elsewhere, in order to make our own favourite experiments towards the ideal social republic of the future; and that a deliberate movement towards greater national self-sufficiency and economic isolation will make our task easier, in so far as it can be accomplished without excessive economic cost. ${ }^{20}$

Ironically, while Keynes would fundamentally reverse course himself, coming to see aggregate demand management and international institutions such as the IMF as the linchpins of a renewed global capitalist system, the genie of experimentation unleashed by the collapse of faith in market institutions lived on to dominate most of the world through much of the postwar era.

\section{The Tripartite World after 1945}

At the end of World War II, the international economic system was in a shambles. International markets for trade in goods, services, and financial assets were essentially nonexistent. International trade was destroyed by currency inconvertibility and a web of protectionist measures stemming from the Great Depression and World War II. When the IMF published its first comprehensive review of exchange rate arrangements in 1950, only five countries had established freely convertible currencies under the standard of article VIII of the IMF Articles of Agreement: the United States and four Latin American countries pegged to the dollar, El Salvador, Guatemala, Mexico, and Panama. ${ }^{21}$ Switzerland, not then a member of the IMF, also had a convertible currency. The IMF characterized another four countries as having effec-

19. Keynes (1933, p. 236).

20. Keynes (1933, p. 241).

21. IMF, Annual Report on Exchange Restrictions, 1950. 
tively convertible currencies, even though they had not yet formally accepted the obligations of article VIII: Cuba, Dominican Republic, Honduras, and Venezuela. As late as 1957, only two more countries had established convertibility subject to article VIII: Canada and Haiti. The members of the European Community established convertibility in 1958. Most other developing and socialist countries postponed the move for decades.

While market-based economic linkages were methodically restored among the leading countries during the 1950s, most of the world's population lived in countries that chose fundamentally nonmarket economic strategies for development. Roughly one-third of the world's population lived in socialist countries (as measured by Kornai for the year 1986); another 50 percent or so lived in countries where governments proclaimed a kind of "third way" between capitalism and socialism, stateled industrialization $(S L I) .{ }^{22}$

In figure 1, we show the time profile of the opening of the world economy in the postwar era, using the specific criteria for openness discussed below and in the appendix. The world economy was essentially closed after World War II, and only around 20 percent of the world's population lived in open economies by 1960 . It was not until 1993 that more than 60 percent of the world's GDP, and more than 50 percent of the world's population, was located in open economies. ${ }^{23}$ The figure extends up to 1994, so that by our criteria, neither Russia nor China is part of the open system. If both of these countries cross the threshold to openness (and trade reforms in 1995 might well lead them to qualify), the proportion of openness by population would jump another 30 percent, to reach around 87 percent of the world's population; and the proportion of openness by GDP would jump by another 15 percent, to reach around 83 percent of the world's GDP (using 1975 weights in both cases).

The governments of almost all the developing countries adopted either socialist or SLI policies after World War II. This was true of the

22. The population in socialist countries is measured by Kornai (1992, pp. 6-7) for 1986. The population under SLI is based on the authors' calculations using data from Summers and Heston (1991).

23. Let $P O_{t}$ be the proportion of the world economies that are open in year $t$, as shown in figure 1. $P O_{t}$ is constructed as $P O_{t}=\sum w_{i 75} D_{i t-1}$, where $D_{i t-1}$ is a dummy variable set equal to one if the country is open as of year $t-1$, and zero otherwise. $w_{i 75}$ is the weight of country $i$ in the world in 1975 . The weights are constructed using 1975 population data and 1975 real GDP data from version 5.6 of the data in Summers and Heston (1991). 
Figure 1. Share of Open Economies in the World, 1960-95

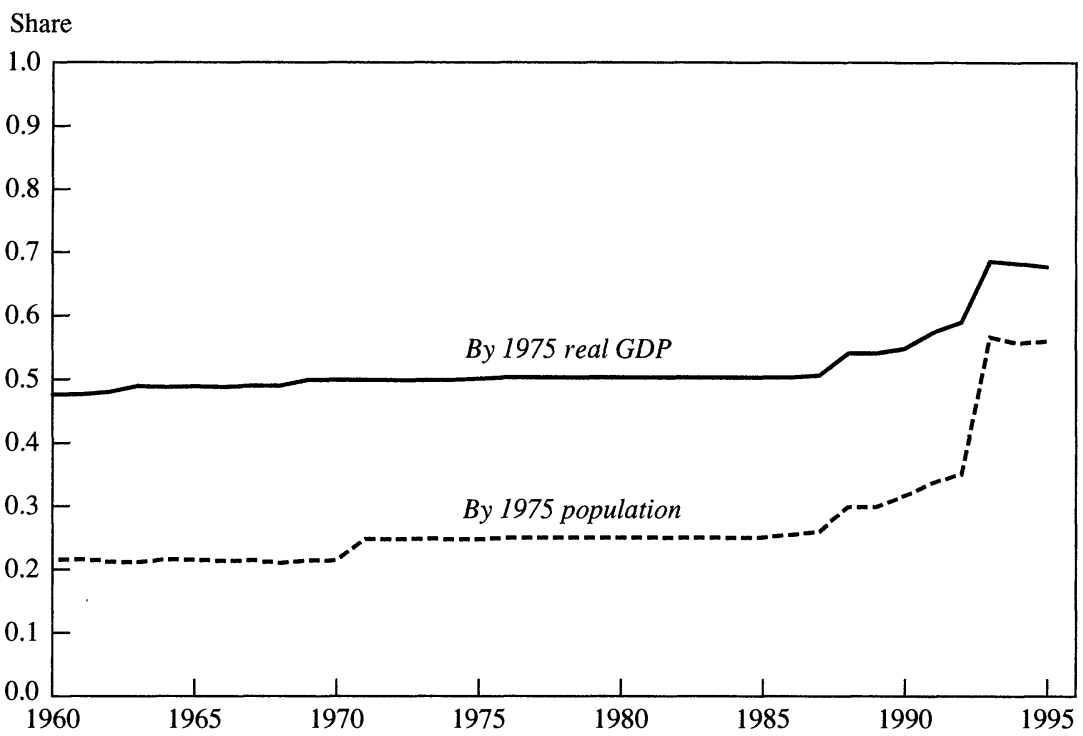

Source: Authors' calculations. The weights are constructed using 1975 population data and 1975 real GDP data from version 5.6 of the data in Summers and Heston (1991).

a. Let $P O_{t}$ be the proportion of the world's economies that are open in year $t$. $P O_{t}$ is constructed as $P O_{t}=$ $\sum w_{i 75} D_{i t-1}$, where $D_{i t-1}$ is a dummy variable set equal to one if the country is open as of year $t-1$, and zero otherwise. $w_{i 75}$ is the weight of country $i$ in the world in 1975 .

long-independent economies of Latin America as well as most of the postcolonial countries of Africa, the Middle East, and Asia as they gained independence. Of course, in the cases of Eastern Europe and the Baltic states, these policies were imposed by the force of the Soviet Union, rather than being the result of indigenous political decisions. More generally, trade policies reflected a wide variety of economic forces, intellectual beliefs, internal political economy, foreign policy considerations, and other economic forces. While no summary can do justice to the complex and myriad forces at play, it is important to review them, if only to appreciate that socialist and SLI policies should be understood mainly as "policy experiments" (albeit enormously mistaken and costly ones), rather than as inevitable consequences of the economic structures of the countries in question.

international ECONOMIC FORCES. Probably the most important factor behind the advent of SLI policies after World War II was the collapse of the world trading system itself. Since almost none of the richer 
countries had convertible currencies or low external tariff rates, the government of any individual developing country naturally viewed its trading prospects with considerable skepticism. This "export pessimism" was shared by a wide range of postwar economic analysts. Moreover, since the value of trade liberalization generally depends on the openness of potential trading partners, the choice of closed trading policies can be understood, in part, as a kind of low-level trading equilibrium. ${ }^{24}$ This explanation helps to account for the delay in liberalization in most developing countries after World War II. It is not as helpful, however, in explaining the behavior of about one dozen countries (mainly in Central and South America, as noted later) that were relatively open in the late 1940 s, but closed up during the 1950 s and early 1960 s. ${ }^{25}$ Nor does the closed nature of the world economy in the late 1940s explain the persistence of closed policies in developing countries even after the United States, Canada, the European Community, and Japan had adopted more outward policies in the $1960 \mathrm{~s}$. A full explanation must therefore look to other factors.

MACROECONOMIC POLICIES. The roots of postwar currency inconvertibility at the end of World War II lay as much in macroeconomics as in trade policy. Although exchange controls were introduced in many countries during the Great Depression, the pressures of wartime inflationary finance were probably an even greater factor in the spread of inconvertibility. In country after country, government wartime purchases were financed through inflationary finance (that is, government borrowing from the central bank), coupled with domestic price controls, foreign exchange controls, and extensive rationing of goods. By the end of the war, there was an enormous overhang of nominal money balances in most countries. In the British Commonwealth, for example, the Indian government held large reserves of sterling which were restricted in use according to imperial monetary policy.

24. Rodriguez (1974), using a two-country model in which each country uses trade quotas to shift the terms of trade in its favor, shows that zero trade is typically the Nash equilibrium, since each country optimally responds to a tightening of trade quotas by similarly tightening its own quotas.

25. The "late protectionists" are shown in table 11: Bolivia, Costa Rica, Ecuador, El Salvador, Guatemala, Honduras, Jamaica, Kenya, Morocco, Nicaragua, Peru, Sri Lanka, Syria, Turkey, and Venezuela. Most of the Central American countries closed during the formation of the Central American Common Market (CACM) in the early 1960s; the Andean countries (Bolivia, Ecuador, Peru, and Venezuela) closed partly as the result of joint actions of the Andean Group, and partly as the result of internal political choices. 
Under these circumstances, the restoration of exchange rate convertibility required either a monetary reform (to remove the monetary overhang); a temporary rise of prices and a currency devaluation (to absorb the monetary overhang through inflation); a long period of real economic growth to raise the demand for nominal money balances; or some combination of the three. Milton Friedman cogently argued that a floating exchange rate (combined with price decontrol) was the best policy: it would establish convertibility, and hence the monetary basis for free trade, automatically and immediately ${ }^{26}$ Most countries, however, shied away from the temporary inflationary consequences that would have accompanied such a move, even though they would have been one-shot rather than ongoing. Largely for this reason, the return to convertibility in Europe and many other parts of the world was delayed for more than a decade after World War II.

In some countries, the consequences were even more long-lasting. In India, for example, various attempts to relax price controls and to reestablish free trade led to a spurt in prices and a subsequent reversal of the policy. ${ }^{27}$ For several years, half-hearted attempts at liberalization were reversed as the result of the accompanying price increases. During this period the ideology of state control gained in importance, as Jawaharlal Nehru consolidated his hold on the Indian leadership. Thus the initial macroeconomic pressures delayed the establishment of convertibility, while ideology and interest-group lobbying cemented the postwar policies of inconvertibility, licensing, and protection.

Even after the 1950s, macroeconomic instability continued to produce closed trade practices in many countries. Throughout Latin America, populist fiscal policies repeatedly undermined the commitment to currency convertibility and allowed the emergence of significant black market premiums on the exchange rate in countries with a pegged rate regime. In this way trade practices were often closed inadvertently, as a result of overly expansionary macroeconomic policies, rather than

26. Friedman (1953) has typically been read as an argument for floating rather than fixed exchange rates. More fundamentally, it is an argument for convertibility (which automatically follows from floating rates) as compared to inconvertibility (which often accompanies a fixed exchange rate regime). Friedman reasoned that a commitment to a fixed exchange rate would almost inevitably lead to balance-of- payments pressures and hence, multiple exchange rates or other forms of inconvertibility. This was certainly the pattern as of 1953.

27. See Tomlinson (1992). 
deliberately. Nonetheless, the economic effects were similar: a rise in the relative prices of import-competing goods, a reduction of imports, and a reduction of exports.

INTELLECTUAL BELIEFS. Several currents of intellectual belief coalesced to support the nearly worldwide adoption of SLI and socialist strategies. Following two world wars and the Great Depression, the liberal world view seemed to be indefensible. Capitalism had proved to be rapacious and violent, as J. A. Hobson and Lenin had predicted. ${ }^{28}$ Even Keynes had subscribed to this view in 1933. Moreover, the Marxist notion that profits were the result of the exploitation of labor was an extraordinarily enticing explanation for elites in the poorer countries, who could justifiably view the poverty of their own nations as the result of degradations committed by the richer nations.

Moreover, as Keynes had seemingly demonstrated, capitalism was inherently unstable and needed the steadying rudder of the state, perhaps in the form of the nearly full nationalization of future investment. It should be remembered that banking, insurance, and much heavy industry were nationalized in France (under Charles De Gaulle) and in Britain (under Clement Atlee) as well as in many other Western European countries, and not just in the developing and socialist worlds.

At the same time, there was a growing belief that coordinated, largescale public investment was necessary to make a breakthrough to modernizing industrialization. Paul Rosenstein-Rodan championed the strategy of the "big push," and Alexander Gershchenkron argued that the idea was supported by the history of nineteenth-century Europe, in which the countries lagging in industrialization increasingly relied on the state to catch up with the richer countries. ${ }^{29}$ The greater the gap at the start of industrialization, according to Gershchenkron, the greater was the state's role in mobilizing resources for the breakthrough. The apparent industrial successes of the Soviet Union, which had proved sufficient to defeat Nazi Germany, seemed to many observers to give ample confirmation of the technical possibilities of investment planning and state-led industrialization. These ideas, backed up by the new techniques of national income accounting, input-output analysis, and mathematical growth models, led to the widespread endorsement of development planning models in mainstream development economics.

28. See Hobson (1902) and Lenin (1926).

29. See Rosenstein-Rodan (1943) and Gershchenkron and Nimitz (1952). 
Export pessimism combined with the idea of the big push to produce the highly influential view that open trade would condemn developing countries to long-term subservience in the international system as raw materials exporters and manufactured goods importers. Comparative advantage, it was argued by the Economic Commission of Latin America (ECLA) and others, was driven by short-run considerations that would prevent raw materials exporting nations from ever building up an industrial base. The protection of infant industries was therefore vital if the developing countries were to escape from their overdependence on raw materials production. These views spread within the United Nations system (to regional offices of the United Nations Economic Commission), and were adopted largely by the United Nations Conference on Trade and Development (UNCTAD). In 1964 they found international legal sanction in a new part IV of the General Agreement on Tariffs and Trade (GATT), which established that developing countries should enjoy the right to asymmetric trade policies. While the developed countries should open their markets, the developing countries could continue to protect their own markets. Of course, this "right" was the proverbial rope on which to hang one's own economy!

More radical anti-capitalist views fueled Marxist-inspired revolutions in nearly two dozen countries during the postwar period. Forrest Colburn offers a masterful evocation of the underlying ideas and symbols common to these revolutions. ${ }^{30} \mathrm{He}$ puts great stress on the role of ideas, rather than the political economy in motivating the revolutionary leaders:

The trajectory of contemporary revolutionary regimes illuminates why, at least in poor countries, the choices of political elites are so consequential. In many such countries, political elites are not significantly constrained by either the institutions and norms of government or by civil society. Thus, the time for experimentation and implementation of ideas can be dangerously compressed..$^{31}$

STATE BUILDING. In his classic analysis of European mercantilism, Eli Heckscher argued that mercantilist trade and industrial policies were a crucial mechanism by which new nation states consolidated their polit-

30. The list, as provided by Colburn (1994, p. 8 ) is as follows: Afghanistan (1978), Algeria (1962), Angola (1975), Benin (1972), Bolivia (1952), Burkina Faso (1983), Burma (1962), Cambodia (1975), China (1949), Cuba (1959), Egypt (1952), Ethiopia (1974), Grenada (1979), Guinea-Bissau (1974), Laos (1975), North Korea (1948), South Yemen (1967), Vietnam (1945). The Iranian revolution (1979) was inspired by Islamic, not Marxist, principles.

31. Colburn (1994, p. 103). 
ical power both relative to competing domestic interest groups (such as guilds and local gentry) and other nations ${ }^{32}$ In this view, it is no accident that Alexander Hamilton championed trade protection in his "Report on the Subject of Manufactures," delivered to the U.S. Congress in 1790, or that Friedrich List championed industrial policy in the period just before German unification. ${ }^{33}$ Both men saw such policies as a part of state building.

In the post-World War II world, the founding fathers of the newly independent industrial economies almost all viewed state-managed development in political as well as economic terms, and specifically as a way to foster national unity and the political power of the national government. Thus, Sukharno of Indonesia, Nehru of India, Nkrumah of Ghana, and Nyerere of Tanzania were as concerned about the political consolidation of power as about economic strategy per se. Moreover, in many of these countries, independence had been the result of a long struggle with the imperial power during which the rallying cry of selfsufficiency had often played a key role in mobilizing the population. Protectionist trade policies and barriers to foreign direct investment seemed to be a vital way to bolster newly won claims of independence.

Trade and industrial policy played an even more direct role in state building when countries used such policies to build up a military-industrial establishment. In Russia and the Soviet Union, for example, from Peter the Great to Stalin the principle aim of heavy industrialization was to bolster the military potential of the state. Similar considerations played a role in many other countries after World War II, such as Nehru's India and Nasser's Egypt. ${ }^{34}$

POLITICAL ECONOMY. Most recent models of trade policy have been based on interest-group politics. ${ }^{35}$ Trade policy is viewed as the outcome of the relative political strengths of various factional, class, or sectoral interests. Such political considerations have surely played an important role in the SLI strategies of developing countries, but more often in the perpetuation of policies than in their onset. John Waterbury gives a careful, detailed account of state-led industrialization in Egypt, India, Mexico, and Turkey, showing that ideology, state building, and

32. Heckscher (1955).

33. See Hamilton (1790) and List (1837).

34. See Waterbury (1993, pp. 69-70).

35. See, for example, Magee (1989) and Grossman and Helpman (1994). 
geopolitics, rather than domestic interest groups, were the fundamental forces that initially led to SLI. ${ }^{36}$ Once SLI policies had built up a protected sector, however, powerful interest groups developed to defend them.

In many cases, protectionist policies had their roots in the enforced autarky of the Great Depression and World War II. Latin America, we have already noted, swung from open trade to protection after the collapse of its export markets in the early 1930s. A domestic import-competing sector arose naturally in the 1930s and 1940s, while at the same time, the wealth and power of the free-trade supporters, the large landowners and mineowners, were sapped by the collapse of the terms of trade. In the immediate postwar era, the import-competing sectors, which now faced the threat of renewed trade competition, added their voices to other forces lobbying in support of state-led, autarkic policies. Similarly, in India, many of the key industrial backers of Nehru's Congress Party had vested interests in the licensing arrangements and protectionism that had been instituted by Britain as part of wartime controls.

In sub-Saharan Africa, the story was similar: wartime controls on agriculture became postwar mechanisms of a profound anti-export bias. As P. T. Bauer brilliantly explained in his early critique of African agricultural monopoly boards, West African Trade, the origins of the marketing board arrangements are found in British wartime policy objectives:

The first was to deny supplies to the enemy and to secure them for the Allies, particularly the United Kingdom. The second objective was the prevention of a collapse of the local price of cocoa. The third principle objective was to increase exports of groundnuts and of oil palm produce after 1942. There were also three principal elements in the machinery of export control. The first was licensing of exports to direct these to specific destinations. The second was statutory monopoly in the handling of the principle exports. The third element was a system of quotas in the purchase of export produce..$^{37}$

Bauer and Robert Bates explain how these original intentions were later subverted into very different aims: the expansion of bureaucratic power; the enhancement of government tax revenues through the mo-

36. Waterbury (1993, p. 10) writes that "for most of the period under scrutiny for each of the cases, the state has enjoyed considerable autonomy from any constellation of class actors."

37. Bauer (1954, p. 246). 
nopoly purchases of agricultural output at below-market prices; and the tilt of the internal terms of trade in favor of urban (largely government) workers, and away from peasant cultivators. ${ }^{38}$

The basic Heckscher-Ohlin-Samuelson (HOS) and Ricardo-Viner (RV) models of trade give some notion of which economic groups in a society should favor trade protection (either import taxation or export taxation), and which should lean toward open trade. According to the HOS model, the move from autarky to trade favors the abundant factors of production and reduces the real income of the scarce factors of production. Thus the relatively scarce factors of production in an economy should tend to be in favor of autarkic policies. The RV theory highlights the implications of factor immobility between sectors. When capital or labor cannot move between sectors, the immobile factors should tend to favor protection for their own sector, irrespective of the overall scarcity or abundance of specific factors of production. Firms with sunk capital in the import-competing sector, and workers with skills specific to that sector, should tend to favor protection of the sector.

Ronald Rogowski and others have examined relative factor intensities to assess the pressures for and against free trade in the postwar era. ${ }^{39}$ Most of the Asian economies tend to have high labor-to-land ratios (land is the scarce factor), suggesting that workers would tend to favor free trade (in order to benefit from the export of labor-intensive goods and the import of inexpensive food), while landowners would tend to favor protection (to raise the price of foodstuffs in the local economy). In Latin America and Africa, where labor is scarce and land is abundant, we would expect the reverse: landowners should be on the side of free trade (to raise the export price of foodstuffs), and urban workers should be interested in protection (against the import of labor-intensive goods and the export of foodstuffs).

Of course, the relative power of the various interests to influence trade policy will depend on a myriad factors, including the capacity of competing groups to organize politically and the institutions for political competition (for example, elections or military rule). In Latin America from the 1950 s to the 1980 s, for example, protectionism tended to be favored during democratic periods, since workers (who, as the scarce factor, favored protection) could outvote landowners; free trade, on the

38. See Bauer (1954) and Bates (1988).

39. Rogowski (1989). 
other hand, was typically promoted by authoritarian governments, siding with large landowners and mineowners. ${ }^{40}$ In many parts of the developing world, especially Latin America and Africa, political power has been disproportionately concentrated in urban areas, thereby adding to the political weight of labor relative to landowners and turning the trade regime more protectionist. ${ }^{41}$

It might seem that a labor-intensive economy would tend to lean more readily toward free trade than would a land-intensive (or resource-intensive) economy. Postwar governments have tended to respond more to labor interests than landowner interests, whether as the result of the search for votes, or the fear of labor unrest, or the urban bias promoted by government-sector workers. If labor interests are indeed the determining factor, then trade liberalization would come more readily in Asia than in Latin America or Africa. But as already noted, interest group politics has hardly been decisive. Some labor-intensive economies, such as the South Asian countries (India, Bangladesh, Pakistan, and Sri Lanka) were long protectionist, while labor-scarce Chile became the first sustained free trader in Latin America (although, notably, under a military regime).

\section{The Classification and Timing of Trade Policies}

The outcome of these various forces produced an overwhelming turn toward socialism or SLI in the developing world during the 1940s and 1950 s, which was only gradually reversed over the next forty years. According to our classifications, shown in tables 1-5, seventy-eight developing countries outside of the Soviet bloc chose some form of inward-looking development strategy in the postwar period. Of these, forty-three had opened their economies by 1994 (see table 2) and thirtyfive were still closed as of 1994 (see table 3). Although developed countries typically started open and remained open throughout the period,

40. One example is Peru, which maintained open trade during the Odria dictatorship, between 1948 and 1956. Trade remained relatively free during the democratic presidency of Manuel Prado (1956-63), but then turned gradually more protectionist under Fernando Belaunde Terry (1963-68). Peru finally embarked on autarkic, socialist policies under a left-wing military dictatorship led by Juan Velasco Alvarado (1968-75). Conversely, it was the Pinochet dictatorship in Chile after 1973 which ended decades of protectionism. For details, see Skidmore and Smith (1984).

41. See Lipton (1976) and Bates (1981). 
Table 1. Developing Economies That Have Always Been Open ${ }^{\mathrm{a}}$

\begin{tabular}{ll}
\hline Country & Year of independence \\
\hline Barbados & 1966 \\
Cyprus & 1960 \\
Hong Kong & not applicable \\
Malaysia & 1963 \\
Mauritius & 1968 \\
Singapore & 1965 \\
Thailand & never colonized \\
Yemen Arab Republic & 1918 \\
\hline
\end{tabular}

Source: See appendix.

a. Since independence, where applicable.

we have found eight other developing countries that followed this pattern (see table 1) and thirteen that had episodes of temporary liberalization (these periods are identified in parentheses in tables 1-5).

A parallel process of liberalization was underway in the developed economies, although integration was typically achieved in the 1950s and 1960s, rather than the 1980s and 1990s (see table 4). Note that for the purposes of this paper, we define developed economies as all countries with a real GDP of $\$ 5,000$ or more in 1970 , according to the purchasingpower adjusted data in Summers and Heston. ${ }^{42}$ This criterion results in a few classifications that are not standard, namely that Ireland, Greece, and Portugal are classified as developing countries, while Trinidad and Tobago and Venezuela are classified as developed. But these unusual classifications have little impact on our main conclusions.

Our categorization and timing of trade liberalization are fundamental to tables 1-5 and the subsequent empirical work. We judge a country to have a closed trade policy if it has at least one of the following characteristics:

1. Nontariff barriers (NTBs) covering 40 percent or more of trade.

2. Average tariff rates of 40 percent or more.

3. A black market exchange rate that is depreciated by 20 percent or more relacive to the official exchange rate, on average, during the 1970s or 1980s.

4. A socialist economic system (as defined by Kornai). ${ }^{43}$

5. A state monopoly on major exports.

42. Summers and Heston (1991).

43. Kornai (1992). 
Table 2. Developing Economies That Had Opened by 1994 after Initial Closure

\begin{tabular}{|c|c|c|c|c|c|c|}
\hline \multirow[b]{2}{*}{ Country } & \multirow{2}{*}{\multicolumn{2}{|c|}{$\begin{array}{c}\text { Year of } \\
\text { opening }\end{array}$}} & \multicolumn{4}{|c|}{ Prior macroeconomic crisis } \\
\hline & & & $\begin{array}{l}\text { External } \\
\text { payments } \\
\text { arrears }\end{array}$ & $\begin{array}{c}\text { External } \\
\text { debt } \\
\text { rescheduling }\end{array}$ & $\begin{array}{c}\text { High } \\
\text { inflation }^{\mathrm{b}}\end{array}$ & Remarks \\
\hline Greece & 1959 & & & & & No crisis \\
\hline Portugal & 1960 & & & & & No crisis \\
\hline Taiwan & 1963 & & & & & $\begin{array}{l}\text { Foreign aid } \\
\text { reduction }\end{array}$ \\
\hline Jordan & 1965 & & & & & No crisis \\
\hline Ireland & 1966 & & & & & No crisis \\
\hline Korea, Republic & 1968 & & & & & $\begin{array}{l}\text { Foreign aid } \\
\text { reduction }\end{array}$ \\
\hline Indonesia & 1970 & & Yes & Yes & 1964 & \\
\hline Chile & 1976 & & & & 1973 & \\
\hline Botswana & 1979 & & & & & No crisis \\
\hline Morocco & 1984 & $(1956-64)$ & 1987 & 1983 & & \\
\hline Bolivia & 1985 & $(1956-78)$ & 1987 & 1980 & 1982 & \\
\hline Gambia & 1985 & & 1987 & 1986 & & \\
\hline Ghana & 1985 & & 1987 & & 1981 & \\
\hline Costa Rica & 1986 & $(1952-61)$ & 1987 & 1983 & & \\
\hline Guinea & 1986 & & 1987 & 1986 & & \\
\hline Mexico & 1986 & & & 1983 & 1983 & \\
\hline Guinea-Bissau & 1987 & & 1987 & 1987 & & \\
\hline Guatemala & 1988 & $(1950-61)$ & 1987 & 1993 & & \\
\hline Guyana & 1988 & & 1987 & 1982 & & \\
\hline Jamaica & 1988 & $(1962-73)$ & 1987 & 1981 & & \\
\hline Mali & 1988 & & 1987 & 1988 & & \\
\hline Philippines & 1988 & & 1989 & 1984 & & \\
\hline Uganda & 1988 & & 1987 & 1981 & 1985 & \\
\hline El Salvador & 1989 & $(1950-61)$ & 1987 & 1990 & & \\
\hline Paraguay & 1989 & & 1987 & & & \\
\hline Tunisia & 1989 & & & & & $\begin{array}{l}\text { Terms-of- } \\
\text { trade decline }\end{array}$ \\
\hline Turkey & 1989 & & & 1980 & 1980 & \\
\hline Benin & 1990 & & 1987 & 1988 & & \\
\hline Uruguay & 1990 & & & 1983 & 1990 & \\
\hline Argentina & 1991 & & & & 1989 & \\
\hline Brazil & 1991 & & 1987 & 1983 & 1981 & \\
\hline Colombia & 1991 & & & & & No crisis \\
\hline Ecuador & 1991 & $(1950-83)$ & 1988 & 1983 & & \\
\hline Honduras & 1991 & $(1950-61)$ & 1987 & 1987 & & \\
\hline Nepal & 1991 & & & & & No crisis \\
\hline Nicaragua & 1991 & $(1950-60)$ & 1987 & 1980 & 1985 & \\
\hline Peru & 1991 & $(1948-67)$ & 1987 & 1980 & 1983 & \\
\hline South Africa & 1991 & & 1987 & 1985 & & \\
\hline Sri Lanka & 1991 & $(1950-56)($ & 83) & & & No crisis \\
\hline Cameroon & 1993 & $(1963-67)$ & 1990 & 1989 & & \\
\hline Kenya & 1993 & & 1993 & & & \\
\hline Zambia & 1993 & & 1987 & 1983 & 1989 & \\
\hline India & 1994 & & & & & No crisis \\
\hline
\end{tabular}

Source: External payments arrears, the variable EPA, are recorded in IMF, Annual Report on Exchange Restrictions, various issues. External debt rescheduling, the variable $D C$, is recorded in World Bank (1994c). See appendix for complete definitions of variables and sources.

a. Dates in parentheses identify temporary liberalizations.

b. High inflation, the variable $H I$, indicates annual inflation exceeding 100 percent. 
Table 3. Developing Economies That Were Closed at the End of 1994a

\begin{tabular}{lll}
\hline Algeria & Ethiopia & Pakistan \\
Angola & Gabon & Papua New Guinea \\
Bangladesh & Haiti & Rwanda \\
Burkina Faso & Iran & Senegal \\
Burundi & Iraq & Sierra Leone \\
Central African Republic & Madagascar & Somalia \\
Chad & Malawi & Syrian Arab Republic (1951-65) \\
China & Mauritania & Tanzania \\
Congo & Mozambique & Togo \\
Cote d'Ivoire & Myanmar & Zaire \\
Dominican Republic & Niger & Zimbabwe \\
Egypt & Nigeria & \\
\hline
\end{tabular}

Source: See appendix.

a. Dates in parentheses identify temporary liberalizations.

We define an open economy as one in which none of the five conditions applies. The basic trade data are shown in table 6. Details on data sources and other data adjustments are given in the appendix. Note that the tariff and nontariff barriers are for the mid-1980s. We have also examined the time series of tariff and nontariff barriers through an independent literature review (also described in the appendix) to judge the timing of the shift from closed to open trade.

In tables 1-5 the date of trade liberalization is taken to be the year from which the economy is open continuously through the end of the sample period, $1994 .{ }^{44}$ For most economies the postwar era is characterized by initial closure (failure on one or more of the five criteria listed above), followed by subsequent opening. For these temporary liberalizers, the date of opening is taken to be the date at which the openness criteria are finally met without subsequent reversal up to 1994 (in effect, ignoring the initial temporary episode of openness). We show below that

44. Our choice of dating is surely subject to further refinement. Our chosen criteria are useful and objective indicators of trade policy, but we recognize that they are too simplistic. The threshold levels (such as a 20 percent black market premium) are arbitrary, and the measurements do not account for the general-equilibrium effects of an array of trade policies. For example, we use nominal tariff rates rather than effective protection rates, and we do not consider the role of export subsidies in offsetting import protection. The quantification of nontariff barriers is also inherently difficult. Perhaps most difficult was judging the year in which openness is first achieved. We relied on a wide array of secondary sources, which sometimes contradicted each other. Despite all of these difficulties, we still believe that our measures of openness and the timing of liberalization convey a substantial amount of information, though with inevitable error. 
Table 4. Developed Economies with Year of Opening

\begin{tabular}{ll}
\hline Country & $\begin{array}{c}\text { Year of } \\
\text { opening }^{\mathrm{a}}\end{array}$ \\
\hline Australia & 1964 \\
Austria & 1960 \\
Belgium & 1960 \\
Canada & 1952 \\
Denmark & 1960 \\
Finland & 1960 \\
France & 1959 \\
Germany & 1959 \\
Israel & 1985 \\
Italy & 1959 \\
Japan & 1962 \\
Luxembourg & 1959 \\
Netherlands & 1959 \\
New Zealand & 1986 \\
Norway & 1960 \\
Spain & 1960 \\
Sweden & 1960 \\
Switzerland & 1950 or earlier \\
Trinidad and Tobago & closed \\
United Kingdom & 1960 \\
United States & 1950 or earlier \\
Venezuela & $(1950-59)(1989-92)$ \\
\hline
\end{tabular}

Source: See appendix.

a. Dates in parentheses identify temporary liberalizations.

the periods of temporary openness were often characterized by sustained economic growth at a higher level than during the subsequent period of closure. Finally, in table 5 we show the liberalization record of the post-socialist European economies, but in this case we rely on EBRD standards of openness.

The five criteria are chosen in order to cover all of the major types of trade restriction. Tariffs and nontariff barriers (mainly quotas) are most obvious. We rely mainly on UNCTAD data for these classifications. The black market premium (BMP) is a measure of exchange control: a large $\mathrm{BMP}$ is evidence of the rationing of foreign exchange, which tends to be a form of import control. The socialist classification is used as an indicator to cover countries like Poland and Hungary, which relied on central planning rather than overt trade policies (for example, tariffs) to maintain a closed economy. Export controls are symmetrical with import controls in their effects on closing an economy, as A. P. Lerner first es- 
Table 5. Post-communist Countries with Year of Opening

\begin{tabular}{|c|c|}
\hline Country & $\begin{array}{c}\text { Year of } \\
\text { opening }\end{array}$ \\
\hline Hungary & 1990 \\
\hline Poland & 1990 \\
\hline Bulgaria & 1991 \\
\hline Czech Republic & 1991 \\
\hline Slovak Republic & 1991 \\
\hline Slovenia & 1991 \\
\hline Albania & 1992 \\
\hline Estonia & 1992 \\
\hline Romania & 1992 \\
\hline Croatia & 1993 \\
\hline Latvia & 1993 \\
\hline Lithuania & 1993 \\
\hline Belarus & 1994 \\
\hline Kyrgyzstan & 1994 \\
\hline FYR Macedonia & 1994 \\
\hline Moldova & 1994 \\
\hline Armenia & closed \\
\hline Azerbaijan & closed \\
\hline Georgia & closed \\
\hline Kazakhstan & closed \\
\hline Russia & closed \\
\hline Tajikistan & closed \\
\hline Turkmenistan & closed \\
\hline Ukraine & closed \\
\hline Uzbekistan & closed \\
\hline Yugoslavia & closed \\
\hline
\end{tabular}

Source: European Bank for Reconstruction and Development (1994).

tablished. ${ }^{45}$ The sub-Saharan African countries relied extensively on export monopolies on foodstuffs, in part to maintain low domestic prices of food for urban residents.

Returning to tables $1-5$, we show that only a few developing countries have been continuously open from the start of the postwar era, or from the start of their independence: Barbados, Cyprus, Hong King, Malaysia, Mauritius, Singapore, Thailand, and the Yemen Arab Republic. Many others embarked on a path of inward-oriented growth in the 1950s or 1960s that was subsequently reversed in the 1970s or later. (Bolivia, Ecuador, and Jamaica closed quite late in the period: 1978, 1983, and 1973, respectively.) Some of the first closed economies to open trade were three East Asian countries: Taiwan (1963), South Korea (1968),

45. See Lerner (1936). 


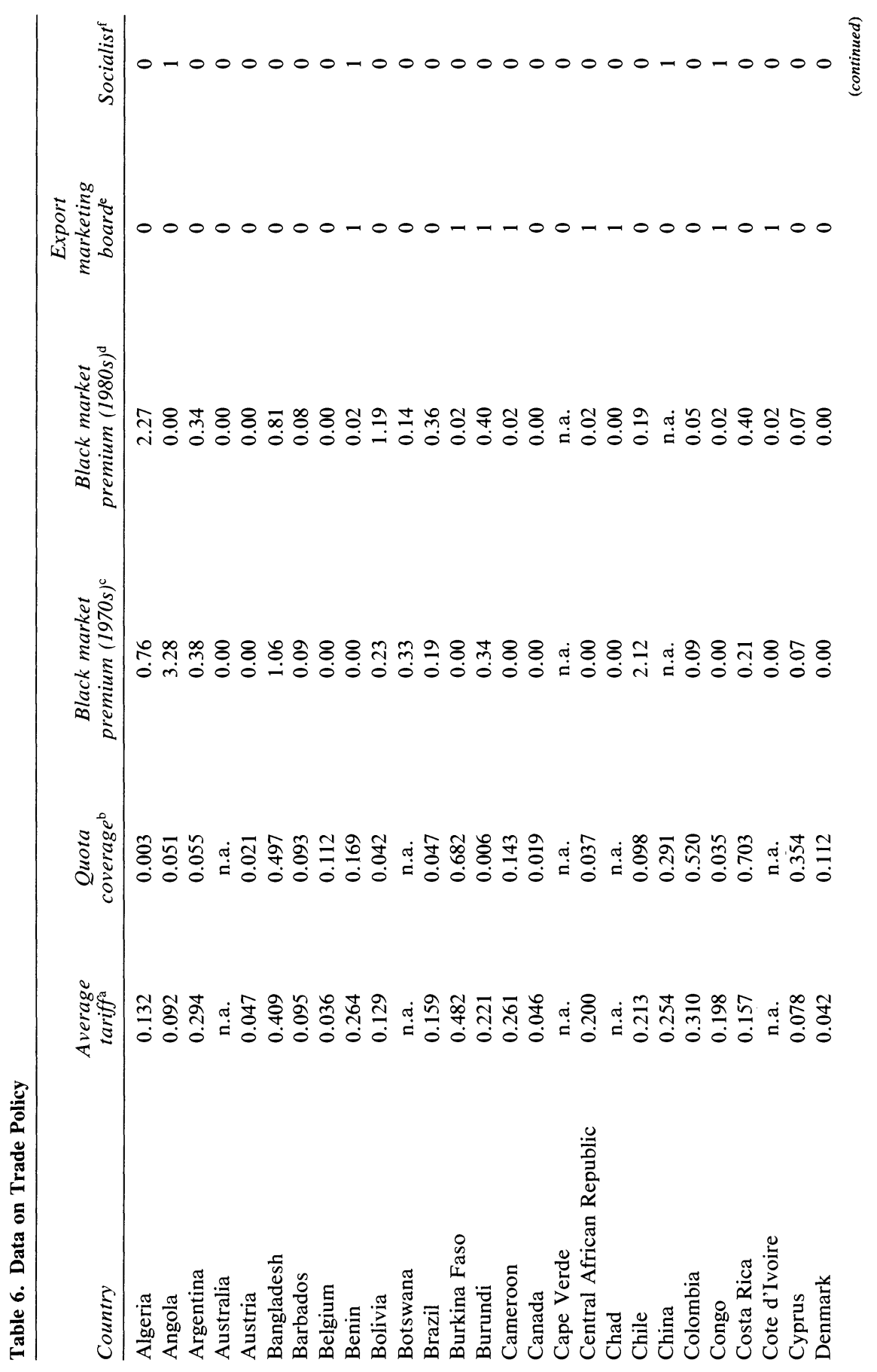




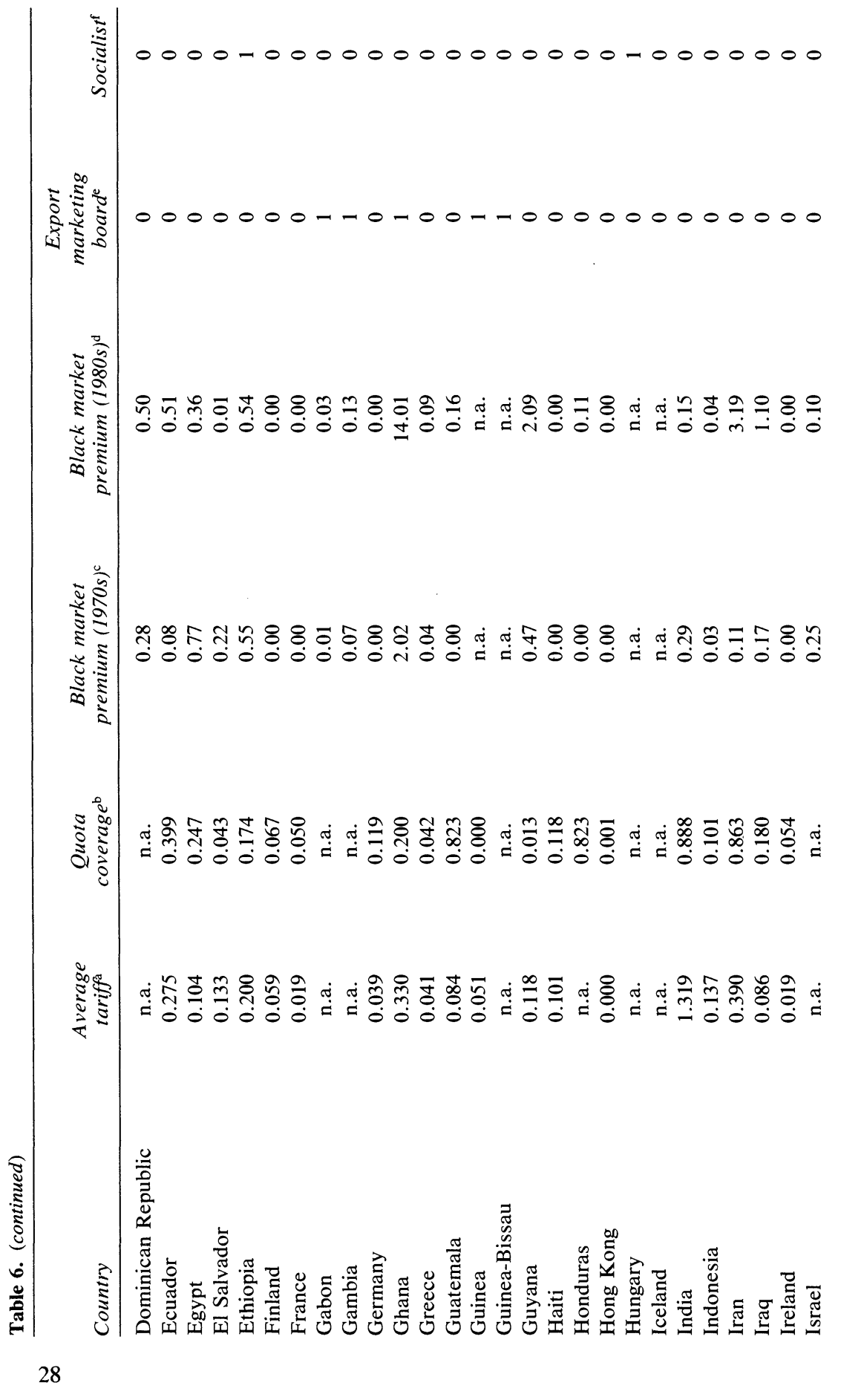


$000000000000000000-0000-00000000$ 竎

$000000000-10-0-000-00000-1000000$

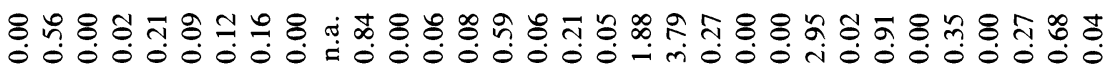

\& ₹ \&

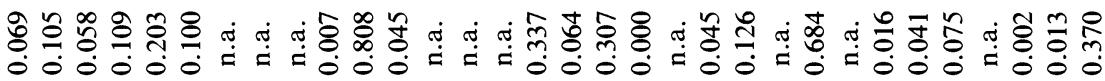

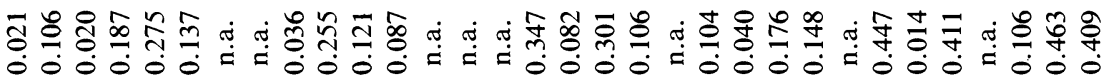

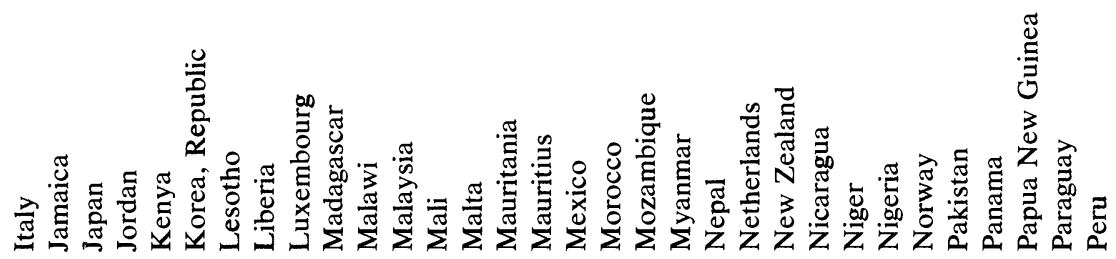




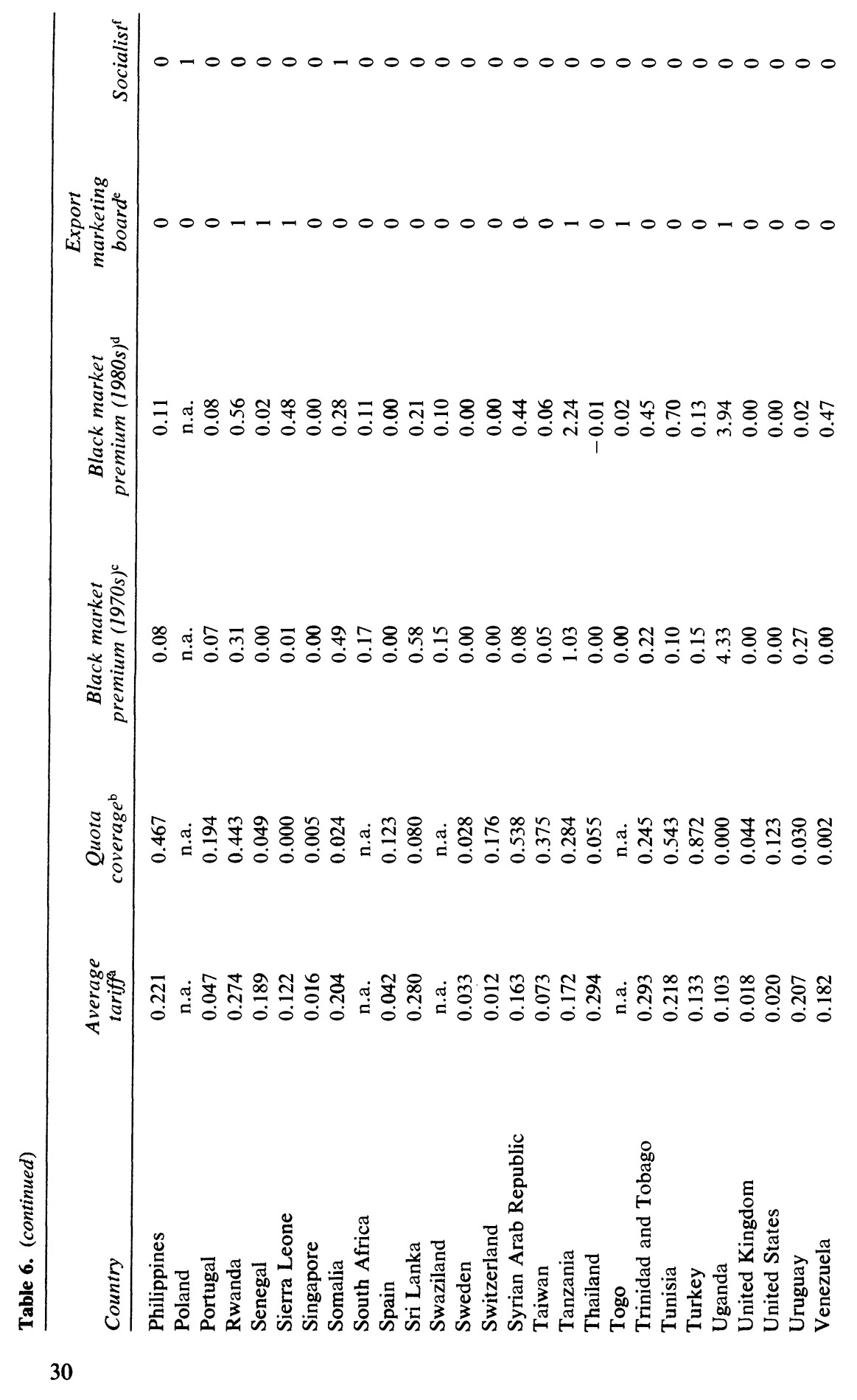




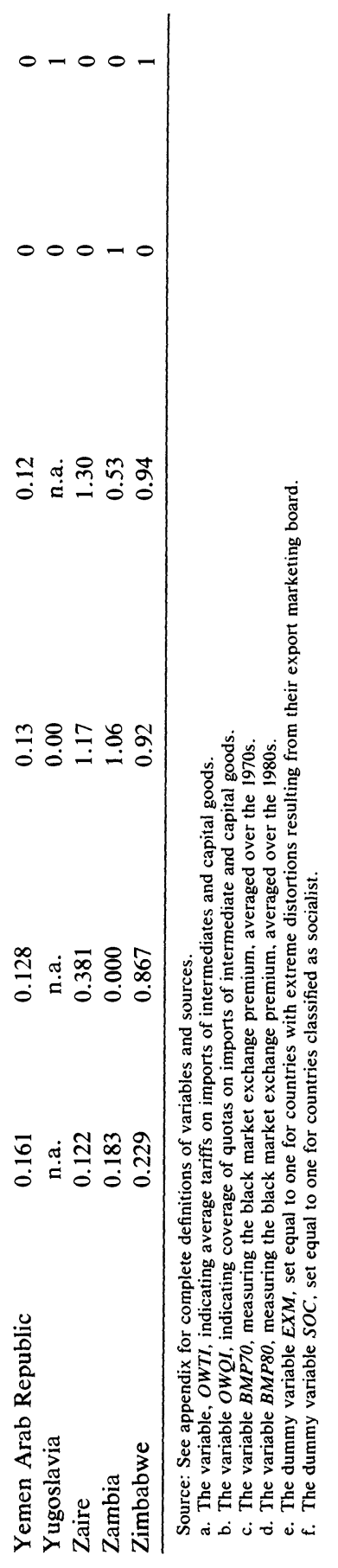


Table 7. Trade Policy Indicators for Asian Economies

\begin{tabular}{|c|c|c|c|c|}
\hline Country & $\begin{array}{c}\text { Black market } \\
\text { premium }(1970 s)^{\mathrm{a}}\end{array}$ & $\begin{array}{c}\text { Black market } \\
\text { premium }(1980 \mathrm{~s})^{\mathrm{b}}\end{array}$ & $\begin{array}{c}\text { Quota } \\
\text { coverage }^{\mathrm{c}}\end{array}$ & $\begin{array}{c}\text { Average } \\
\text { tariff }^{\mathrm{d}}\end{array}$ \\
\hline Hong Kong & 0.00 & 0.00 & 0.00 & 0.00 \\
\hline Korea & 0.09 & 0.09 & 0.10 & 0.14 \\
\hline Singapore & 0.00 & 0.00 & 0.01 & 0.02 \\
\hline Taiwan & 0.05 & 0.06 & 0.38 & 0.07 \\
\hline Indonesia & 0.03 & 0.04 & 0.10 & 0.14 \\
\hline Malaysia & 0.00 & 0.00 & 0.05 & 0.09 \\
\hline Thailand & 0.00 & 0.00 & 0.06 & 0.29 \\
\hline \multicolumn{5}{|c|}{ All developing countries } \\
\hline Median & 0.17 & 0.18 & 0.14 & 0.19 \\
\hline Mean & 0.44 & 0.70 & 0.26 & 0.22 \\
\hline
\end{tabular}

Source: See appendix for complete definitions of variables and sources.

a. The variable $B M P 70$, measuring the black market exchange premium, averaged over the 1970 s.

b. The variable $B M P 80$, measuring the black market exchange premium, averaged over the $1980 \mathrm{~s}$.

c. The variable $O W Q I$, indicating coverage of quotas on imports of intermediates and capital goods.

d. The variable $O W T I$, indicating average tariffs on imports of intermediates and capital goods.

and Indonesia (1970). It has become fashionable to argue that East Asian countries are not really open or market-oriented, and that, in fact, they systematically "got the prices wrong" to spur industrial growth. ${ }^{46}$ It is surely true that Korea, Taiwan and Indonesia are not laissez faire, but they and their neighbors in Southeast Asia, Thailand and Malaysia, have been more open to trade than other developing countries, based on objective indicators of trade policy, shown in table 7. All of the East Asian economies have low or zero BMPs; all but Thailand have low tariff rates; and all but Taiwan have low NTB coverage. Moreover, the Thai tariffs and the Taiwanese NTBs are moderate, not extreme.

In a later paper we intend to specify a detailed model of the timing of liberalization during the postwar period. Here we simply test a few of the simplest propositions that arise from political economy considerations: that timing should be related to the relative endowments of labor and land, the size of the economy, the per capita income, and perhaps the previous political history (for example, number of years since independence). As described above, we would expect the transition to openness to be faster in land-scarce and labor-abundant economies, since it is plausible that governments will tend to be more responsive to the interests of labor over landowners. We would also expect the transition to

46. See Wade (1990) with regard to Hong Kong, South Korea, Singapore, and Taiwan, and Amsden (1989) with regard to South Korea. 
openness to be earlier in less populous economies, since the gains from trade are presumably larger for an economy with a small domestic market. We would also expect that countries that begin the postwar era with a high per capita income would be more likely to liberalize, because of a higher initial level of division of labor and degree of specialization within the economy. Finally, we would expect that postcolonial countries would be less likely to liberalize (because of the "imperatives" of nationbuilding) than countries that have long been independent.

To test these propositions, we estimate the following logit model:

$$
\operatorname{Pr}\left(T L_{i}=1\right)=\exp \left(\beta^{\prime} X_{i}\right) /\left[1+\exp \left(\beta^{\prime} X_{i}\right)\right],
$$

where $T L_{i}$ is a dummy variable equal to 1 if country $i$ liberalized between 1955 and 1970, and equal to 0 if the country did not liberalize before 1970 . There are sixteen developing countries for which $T L_{i}=1$. The vector of $X$ s includes: the land-to-population ratio in 1960 as a proxy for the landto-labor ratio, the population in 1960, the per capita GDP in 1970, and a dummy variable for postcolonial status (equal to 1 if independent before 1945). We also include a dummy variable if the country is a British Commonwealth country, and another dummy variable if it is a former French colony, on the grounds that the type of colonial relationship might affect the timing of postcolonial trade liberalization ${ }^{47}$ Our sample includes all countries with GDP per capita of less than \$5,000 in 1970.

The results are shown in table 8 . As expected, we find statistical evidence that a high population-to-land ratio raised the probability of an early trade liberalization. This fact helps to account for the early liberalization in much of Southeast Asia. Similarly, high-income countries tended to liberalize ahead of low-income countries. Surprisingly, size of population did not prove to be significant. We also see that not a single former French colony opened to trade during the period 1955-70. Several former British colonies did open to trade, but several others did not. The dummy variable for British Commonwealth status was not statistically significant.

\section{Liberalization Episodes in the 1950s and 1960s}

While the typical developing country started out as a closed economy and liberalized later, we have identified fifteen countries that had an ini-

47. For example, liberalization of former French colonies in Africa has tended to be delayed because of overvalued exchange rates in the French franc zone. 
Table 8. Logit Regressions to Explain Timing of Liberalization in Developing Countries ${ }^{\mathrm{a}}$

\begin{tabular}{lcc} 
Independent variable & Estimated coefficient & Significance level \\
\hline Population in $1960^{\mathrm{b}}$ & -0.000 & {$[0.699]$} \\
${\text { Population/land in } 1960^{\mathrm{c}}}^{\mathrm{G}}$ & 9.520 & {$[0.024]$} \\
${\text { GDP in } 1970^{\mathrm{d}}}_{\text {Postcolonial }^{\mathrm{e}}}$ & 0.0007 & {$[0.040]$} \\
British Commonwealth $^{\mathrm{f}}$ & -0.665 & {$[0.571]$} \\
Summary statistic & -0.237 & {$[0.815]$} \\
Sample size & & \\
\hline
\end{tabular}

Source: Authors' regressions, using data described in the appendix.

a. The regression model is from equation 1 of the text. We created a dummy variable, $T L$, that takes the value 1.0 if a developing country opened by 1970 and stayed open. The logit specification then estimates a model where prob $\left[T L_{i}=1\right]=\exp \left(\beta X_{i}\right) /\left[1+\exp \left(\beta X_{i}\right)\right]$, where the $X \mathrm{~s}$ are the independent variables. These regressions were originally estimated with a variable that measured whether the country was a French colony. This variable perfectly predicted not opening (no former French colony opened before 1970), so the model above is estimated without these fifteen countries. To assess the fit of the estimated model, note that of the fifty-six countries that did not open, fiftyfive had predicted probabilities of opening of less than 0.5 . Of the sixteen countries that did open, seven had predicted probabilities of more than 0.5

b. The variable $P O P 60$, measuring population in 1960 in thousands.

c. The variable POP60/LAND, measuring population in 1960 in thousands, divided by land area in square meters.

d. The variable GDP70.

e. The dummy variable $O L D S$, set equal to one for countries that achieved independence before World War II

f. The dummy variable $C W$, set equal to one for countries in the British Commonwealth.

Table 9. Growth Rates during and after Temporary Liberalization Episodes Percent

\begin{tabular}{|c|c|c|c|c|}
\hline \multirow[b]{2}{*}{ Country } & \multicolumn{2}{|c|}{ Trade policy } & \multicolumn{2}{|c|}{ Average per capita growth } \\
\hline & Open & Closed & Open & Closed \\
\hline Bolivia $^{a}$ & $1956-78$ & $1979-85$ & 2.49 & -2.52 \\
\hline Costa Rica & $1952-61$ & $1962-86$ & 3.39 & 1.84 \\
\hline Ecuador $^{\mathrm{b}}$ & $1950-82$ & 1983-91 & 2.64 & -0.31 \\
\hline El Salvador & $1950-61$ & $1962-89$ & 1.72 & 0.93 \\
\hline Guatemala & $1950-61$ & $1962-88$ & 0.86 & 0.91 \\
\hline Honduras & $1950-61$ & $1962-91$ & 0.49 & 1.22 \\
\hline Jamaica & $1962-73$ & $1974-88$ & 4.15 & -0.65 \\
\hline Kenya & $1963-67$ & 1968-92 & 2.94 & 1.67 \\
\hline Morocco & $1956-64$ & $1965-84$ & 4.15 & 2.14 \\
\hline Nicaragua & $1950-60$ & 1961-91 & 7.20 & 0.55 \\
\hline Peru & $1948-67$ & 1968-91 & 3.51 & -0.64 \\
\hline Sri Lanka & $1950-56$ & $1957-77$ & 0.48 & 1.23 \\
\hline Syria & $1951-65$ & $1966-92$ & 6.51 & 3.16 \\
\hline Turkey & $1950-53$ & $1954-89$ & 11.67 & 2.40 \\
\hline Venezuela $^{\mathrm{d}}$ & $1950-59$ & $1960-89$ & 3.88 & -0.45 \\
\hline
\end{tabular}

Source: Authors' calculations, using real per capita growth data taken from version 5.6 of the data contained in Summers and Heston (1991), and the country sources described in the appendix.

a. A reasonable argument can be made to classify Bolivia as open from 1956 to 1968 , rather than to 1978 ; in which case average growth during the open period would be 2.41 .

b. A reasonable argument can be made to classify Ecuador as open from 1950 to 1970 , rather than to 1982 ; in which case average growth during the open period would be 2.04

c. Sri Lanka also had a temporary liberalization episode in 1977-83, during which growth was 5.37.

d. Venezuela also had a temporary liberalization episode in 1989-92, during which growth was 6.17. 
tial episode of temporary liberalization. In almost all cases, these are countries that had a tradition of open trade, which was resurrected immediately following the Second World War. Table 9 lists these countries and the dates of the temporary liberalization as well as the average growth rates, both during the open period and the subsequent closed period. We find that in twelve of the fifteen cases, average growth in the open period exceeded that in the subsequent closed period. This is important because it suggests that the eventual decision to close the economy was generally not caused by slow growth during the open period, but rather by political and ideological shifts within each country. This is corroborated by economic histories of these countries, which rarely give slow growth as a reason for the policy switch. In the notes to the table, we also report high average growth rates in two later temporary liberalizations, in Sri Lanka and Venezuela. Overall, we find little direct evidence that slow growth played an important role in ending these episodes of liberalization.

\section{The Impact of Postwar Global Integration on Economic Performance, 1970-89}

In this section we show that during the period 1970-89 open economies outperformed closed economies on three main dimensions of economic performance: economic growth, avoidance of extreme macroeconomic crises, and structural change. In the process we demonstrate the close relationship between economic integration and economic convergence, that is, poor countries tend to grow faster than richer countries, as long as the poor and rich countries are linked together by international trade. Poor, closed economies have often performed significantly less well than the richer countries.

For the purposes of this section, we define a country as open if it satisfies the five policy criteria for the duration of the 1970s and 1980s. Countries that were closed during part of this period but subsequently liberalized are treated as closed economies. In the following section, we pick up the trail of those economies by examining the effects of relatively late trade liberalization on economic performance.

\section{Openness and Growth}

During 1970-89, we find a strong association between openness and growth, both within the group of developing and the group of developed 
Table 10. Developing Country Growth and Openness, 1970-89a

\begin{tabular}{lcc}
\hline Growth rate $^{b}$ & $\begin{array}{c}\text { Always } \\
\text { open }\end{array}$ & $\begin{array}{c}\text { Not always } \\
\text { open }\end{array}$ \\
\hline $\begin{array}{l}\text { Average growth } \\
>3.0\end{array}$ & 11 & 4 \\
$\begin{array}{l}\text { Average growth } \\
<3.0\end{array}$ & 4 & 70 \\
\hline $\begin{array}{l}\text { Source: See appendix. } \\
\text { a. In a test of independence the chi square is } 41 \text { (significance level }=0.000) .\end{array}$ \\
b. The growth variable is $G 7089$, the real annual per capita growth in GDP over 1970-89, described in the appendix.
\end{tabular}

countries. Within the group of developing countries, the open economies grew at 4.49 percent per year, and the closed economies grew at 0.69 percent per year. Within the group of developed economies, the open economies grew at 2.29 percent per year, and the closed economies grew at 0.74 percent per year. ${ }^{48}$

We may also classify the data in a different way to focus on growth within the open and closed groups. Within the closed group, average growth is about the same for the poorer developing countries $(0.69$ percent) as the richer developed countries ( 0.74 percent). However, within the group of open economies, the developing countries grew faster (4.49 percent) than the developed countries ( 2.29 percent). This suggests that within the group of open economies, both developing and developed, we should tend to observe economic convergence. Another way to look at this is provided by table 10 which shows the frequency of growth rates above and below 3 percent per year for closed and open developing countries. Eleven of the fifteen open economies grew at more than 3 percent per year, while only four of seventy-four closed economies achieved such growth. For this cross-tabulation, $\chi^{2}=41(p<0.000)$, so that we may reject the null hypothesis of no difference in growth rates between the closed and open economies.

Figure 2 shows the average annual growth rates for a group of forty always-closed developing economies and a group of eight always-open developing economies during the period 1965-90. As can be seen, the

48. Four developed economies were closed for part of the period: Israel, New Zealand, Trinidad and Tobago, and Venezuela. While three of these countries are not normally classified as developed, on a purchasing power parity basis, their per capita GDP exceeded $\$ 5,000$ in 1970 , and thus they qualify as developed by the standard used in this paper. 
Figure 2. Average Growth of Eight Always Open and Forty Always Closed Economies, 1966-90

Growth rate ${ }^{\mathrm{a}}$

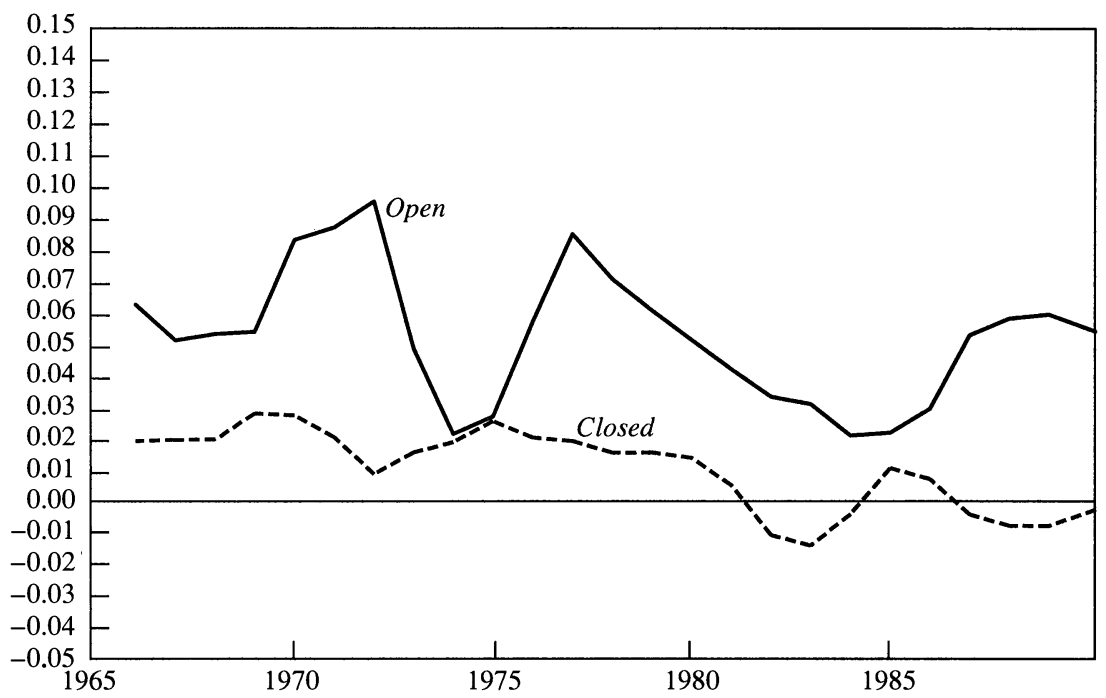

Source: Authors' calculations using version 5.6 of the data in Summers and Heston (1991).

a. Figure shows three-year moving averages.

always-open economies outperformed the always-closed economies in every year. The open economies were clearly more susceptible to the external shocks of the first half of the 1970s (the breakdown of Bretton Woods, worldwide inflation, and the OPEC oil price increases), but then bounced back. Note that the average per capita growth rates of the open economies at the end of the 1980s was about the same as during the second half of the 1960s, around 5 or 6 percent per year. The closed economies, by contrast, evidence a long-term slowdown in growth ( 2 or 3 percent per year in the late $1960 \mathrm{~s}$, around 0 percent per year in the late 1980s).

The data suggest that the absence of overall convergence in the world economy during the past few decades might well result from the closed trading regimes of most of the poorer countries. We now investigate the issue of convergence in greater detail. Our starting point is figure 3 . We graph on the $x$-axis the 1970 level of per capita GDP of our sample of countries and on the $y$-axis, the growth of per capita GDP for 1970-89.49

49. The exact definitions of the data and the selection of countries are described in the appendix. 
Figure 3. Growth and Initial Income, All Economies, 1970-89

Annual growth per capita (percent)

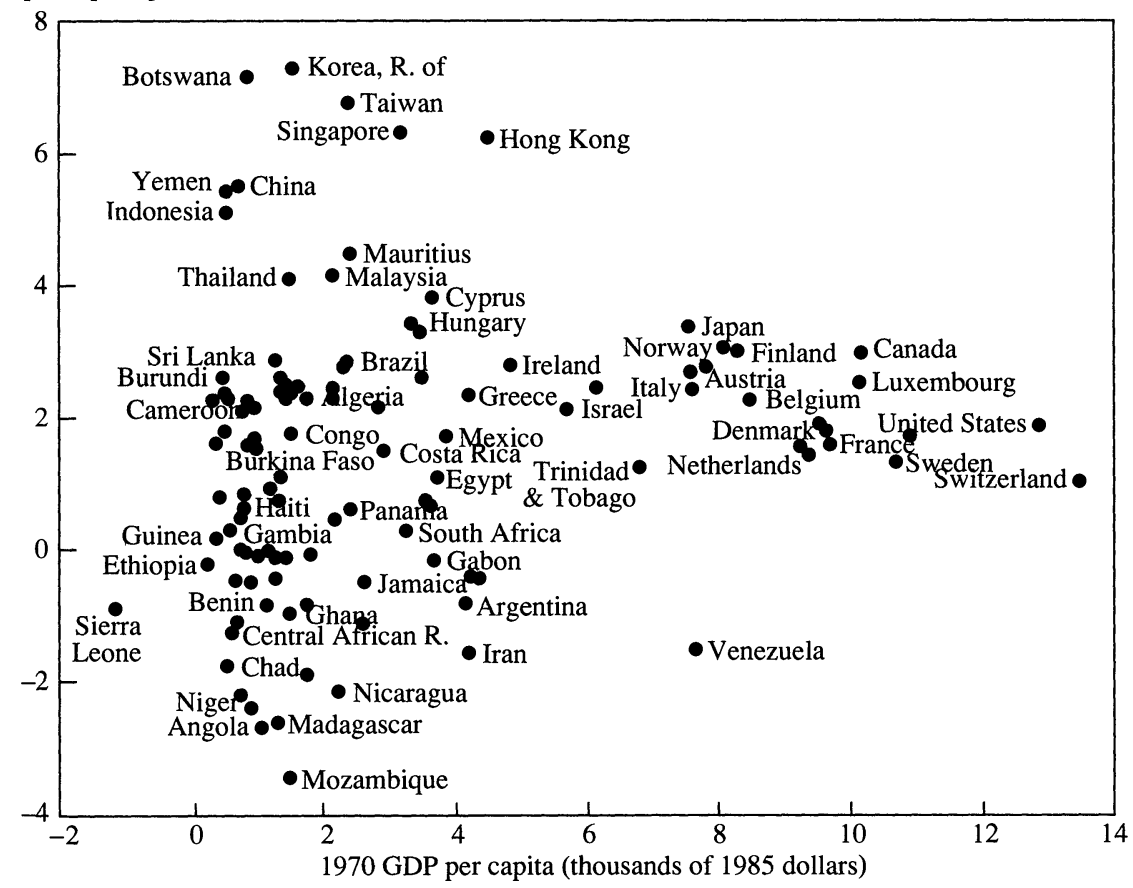

Source: Version 5.5 of the data in Summers and Heston (1991) and World Bank (1994d).

If convergence predominated in the data, then there would be a negative relationship between initial income in 1970 and subsequent growth between 1970 and 1989. No such tendency is found overall in the world economy. Many poor countries, particularly those in sub-Saharan Africa, not only fail to grow faster than the rich countries; they in fact experience negative per capita growth, so that the gap between these countries and the rich countries widens significantly.

When Paul Romer first introduced the conundrum of nonconvergence to the economics profession in his path-breaking 1986 analysis, he suggested that it might be due to the fundamental nature of economic growth. ${ }^{50}$ Romer showed that if production is subject to spillovers of knowledge in the production process, so that learning or skills developed in one part of the economy raise the productivity of other parts of

50. Romer (1986). 
the economy, then the aggregate economy may be freed from the diminishing marginal productivity of capital that is characteristic of standard production processes. In this case, the rich countries could continue to stay ahead of the poor countries, since their higher income would reflect higher levels of learning or human skills, which in turn would raise the future productivity of capital.

Romer's hypothesis, while intriguing, seems to be contradicted by other data, which show convergence within more restricted subsamples of economies. For example, Steve Dowrick and Duc-Tho Nguyen show that the advanced economies of the Organisation for Economic Co-operation and Development (OECD) displayed strong tendencies of convergence in the postwar period, with the relatively poor OECD economies tending to grow more rapidly than the richer economies, thereby closing the proportionate income gap. Similarly, Williamson and associates in several studies find evidence for convergence among the leading economies during the period of internationalization at the end of the nineteenth century. Robert Barro and Xavier Sala-i-Martin find strong evidence of convergence in living standards among U.S. states and Japanese prefectures. Dan Ben-David shows strong convergence among the members of the European Community and the European Free Trade Area, with the dispersion of income falling as trade liberalization proceeded. ${ }^{51}$

The contrasting evidence has given rise to two related hypotheses. William Baumol and others have suggested that there may be a convergence club, meaning a subset of countries for which convergence applies, while countries outside of the club would not necessarily experience convergence relative to those within it: "It also seems clear that convergence does not apply to the poorest of the world economies, though the line separating those eligible for membership in the convergence club and those foreclosed from membership has not been determined definitively." ${ }^{2}$ Baumol suggests that only countries with an adequate initial level of human capital endowments can take advantage of modern technology to enjoy convergent growth. He therefore speaks of the "advantages of moderate backwardness," arguing that while middleincome developing countries can take advantage of their lag in technol-

51. See Dowrick and Nguyen (1989), Williamson (1992), Barro and Sala-i-Martin (1991), and Ben-David (1993).

52. Baumol, Nelson, and Wolff (1994, p. 82). 
ogy to borrow from abroad, the poorest countries are unable to bridge the gap in technology and knowledge..$^{53}$

Barro and Sala-i-Martin have introduced the related notion of conditional convergence, in which countries differ in their long-run per capita income levels, with each country tending to grow more rapidly the greater is the gap between its initial per capita income level and its own long-run per capita income level. ${ }^{54}$ Formally, country $i$ is assumed to have the long-run per capita income level $y_{i}{ }^{*}$, and initial per capita income level $y_{i}$. The rate of growth, $\dot{y}_{i}$, is assumed to be an increasing function of the gap between $y_{i}{ }^{*}$ and $y_{i}$ :

$$
\dot{y}_{i}=\beta\left(y_{i}^{*}-y_{i}\right) \text {. }
$$

A positive value of $\beta$ is said to signify conditional convergence. In turn, $y_{i}{ }^{*}$ is proxied by certain "structural" variables, $Z_{j i}$, such as the initial level of human capital, according to an equation $y_{i}{ }^{*}=\Sigma \gamma_{j i} Z_{j i}$. Barro and others then estimate a regression equation of the form:

$$
\dot{y}_{i}=\beta\left(\Sigma \gamma_{j i} Z_{j i}-y_{i}\right) \text {. }
$$

They tend to find a negative and significant coefficient for initial income, $y_{i}$, and significant coefficients on several of the structural variables, $Z_{j i} .{ }^{5}$

Like Baumol, Barro concludes that "a poor country tends to grow faster than a rich country, but only for a given quantity of human capital; that is, only if the poor country's human capital exceeds the amount that typically accompanies the low level of per capita income." ${ }^{56}$ More recently, Robert Barro, Gregory Mankiw, and Xavier Sala-i-Martin state that the "substantially different steady states . . . can reflect the effects of disparities in preferences and government policies on the saving rate, fertility, and the available production technology." 57

In summary, there have been three dominant explanations offered in

53. Baumol, Nelson, and Wolff (1994, p. 65).

54. See Barro (1991) and Barro and Sala-i-Martin (1991, 1992a).

55. The finding of conditional convergence is now fairly well established in the empirical literature. A number of studies have found this result using post-World War II data with different conditioning variables. The list includes Barro (1991), De Long and Summers (1991), King and Levine (1993), Levine and Renelt (1992), Mankiw, Romer, and Weil (1992), and Sachs and Warner (1995).

56. Barro (1991, p. 409).

57. Barro, Mankiw, and Sala-i-Martin (1995, p. 103). 
the literature for the absence of convergence shown in figure 3 . The first holds that productive technology is intrinsically kind to the technological leader: the rich tend to grow richer as a result of increasing returns to scale in one form or another. ${ }^{58}$ The second holds that convergence is a fact of life, but only among countries with a sound human capital base for using modern technology. The third holds that currently poor countries have a low long-term potential income level $\left(y_{i}^{*}\right)$, though countries do tend to grow faster the greater is the gap between their current income and their own long-run potential.

The first two interpretations, and possibly the third, would be profoundly pessimistic for the poorer countries today, since they suggest that the poorer countries will be unable to close the gap with the richer countries. The conditional convergence hypothesis is ambiguous on this fundamental point. If the low long-term potential income of the poor countries that it posits is due to preferences and initial skill levels, then it too is profoundly pessimistic. In this case the hypothesis is akin to Baumol's convergence club. On the other hand, if the low long-term potential income is due to bad policies, then convergence could still be achieved by policy changes.

We suggest that the most parsimonious reading of the evidence is that convergence can be achieved by all countries, even those with low initial levels of skills, as long as they are open and integrated in the world economy. In this interpretation, the convergence club is the club of economies linked together by international trade: thus the OECD, the European Community, the late-nineteenth-century economies, the U.S. states, and the Japanese prefectures all tend to show convergence. In terms of the conditional convergence hypothesis, we argue that the apparent differences in long-term income levels are not differences due to fundamental tastes and technologies, but rather to policies regarding economic integration.

The role of policy choices in convergence is dramatically evident in figures 4 and 5 , where we divide the sample in figure 3 into groups of open and closed economies. Figure 4 shows that the open countries display a strong tendency toward economic convergence, and that the countries with initially low per capita income levels grow more rapidly

58. Increasing returns to scale is shorthand for a wide variety of technological possibilities, such as learning by doing, spillovers in knowledge accumulation, agglomeration economies among suppliers of specialized inputs to production, etc. 
Figure 4. Growth and Initial Income, Open Economies, 1970-89

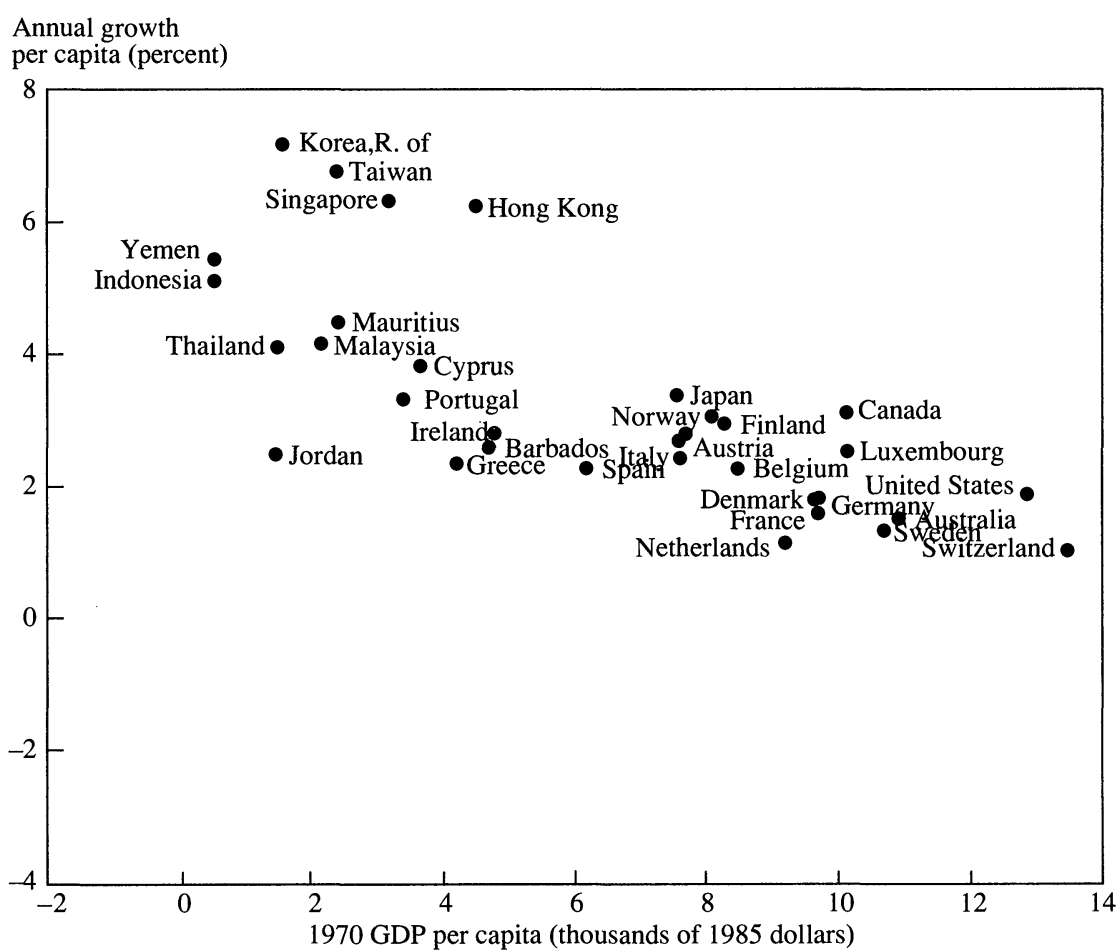

Source: Authors' calculations using version 5.5 of the data in Summers and Heston (1991).

than the richer countries. ${ }^{59}$ The closed economies in figure 5 do not display any tendency toward convergence. In fact, they are clearly the source of the failure of convergence noted in figure 3. Even more striking, there is not a single country in our sample (which covers 111 countries and approximately 98 percent of the non-communist world in 1970) which pursued open trade policies during the entire period 1970-89 and yet had per capita growth of less than 1.2 percent per year (Switzerland had the lowest growth, at 1.24 percent). And not a single open developing country grew at less than 2 percent per year (Greece, at 2.38 percent, and Jordan, at 2.58 percent, are the lowest)!

59. The open economies also exhibit convergence in the sense of having a declining dispersion of GDP over time (sigma-convergence in Barro and Sala-i-Martin's terminology). For the open economies the standard deviation of the log of GDP was 0.83 in 1970 and 0.75 in 1989. 
Figure 5. Growth and Initial Income, Closed Economies, 1970-89

Annual growth

per capita (percent)

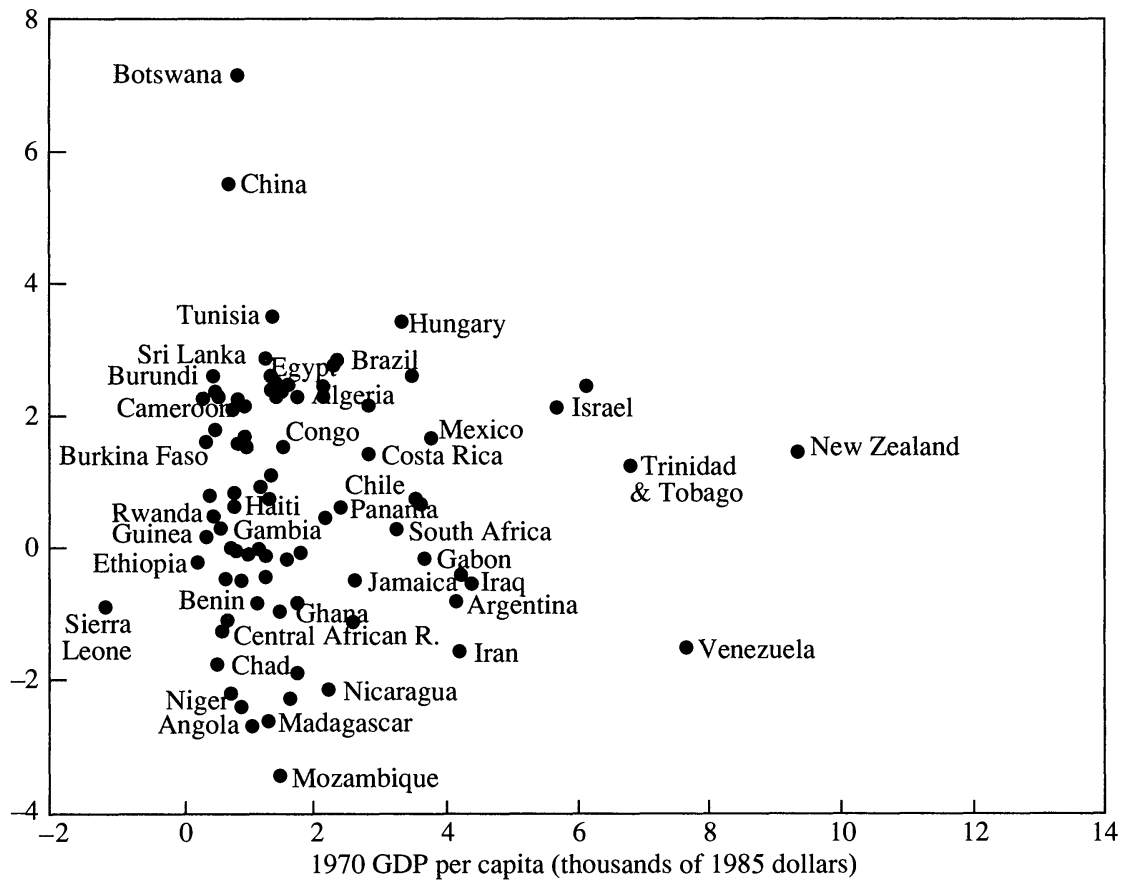

Source: Authors' calculations using version 5.5 of the data in Summers and Heston (1991) and World Bank (1994d).

So far we have analyzed growth per capita rather than growth per worker. The reason is that per capita growth rates are available for a longer time span than the per worker growth rates, which often rely on less frequent census data. However, since some theories (the Solow model in particular) predict convergence more precisely in terms of growth per worker, it is worth examining the available data on such growth. Figure 6 presents figure 4 redrawn with growth per worker on the $y$ axis (covering the period 1970-85 rather than 1970-89). The negative relation between growth and initial income is more clearly evident in this figure than in figure $4 .^{60}$ Based on this evidence, if growth per worker were available for the full time period, we would expect it to strengthen our conclusions regarding convergence, but the minimum

60. This result, that per worker growth exhibits stronger evidence for convergence than per capita growth, is also observed by Wolf (1994). 
Figure 6. Growth Per Worker and Initial GDP Per Worker, Open Economies, 1970-85

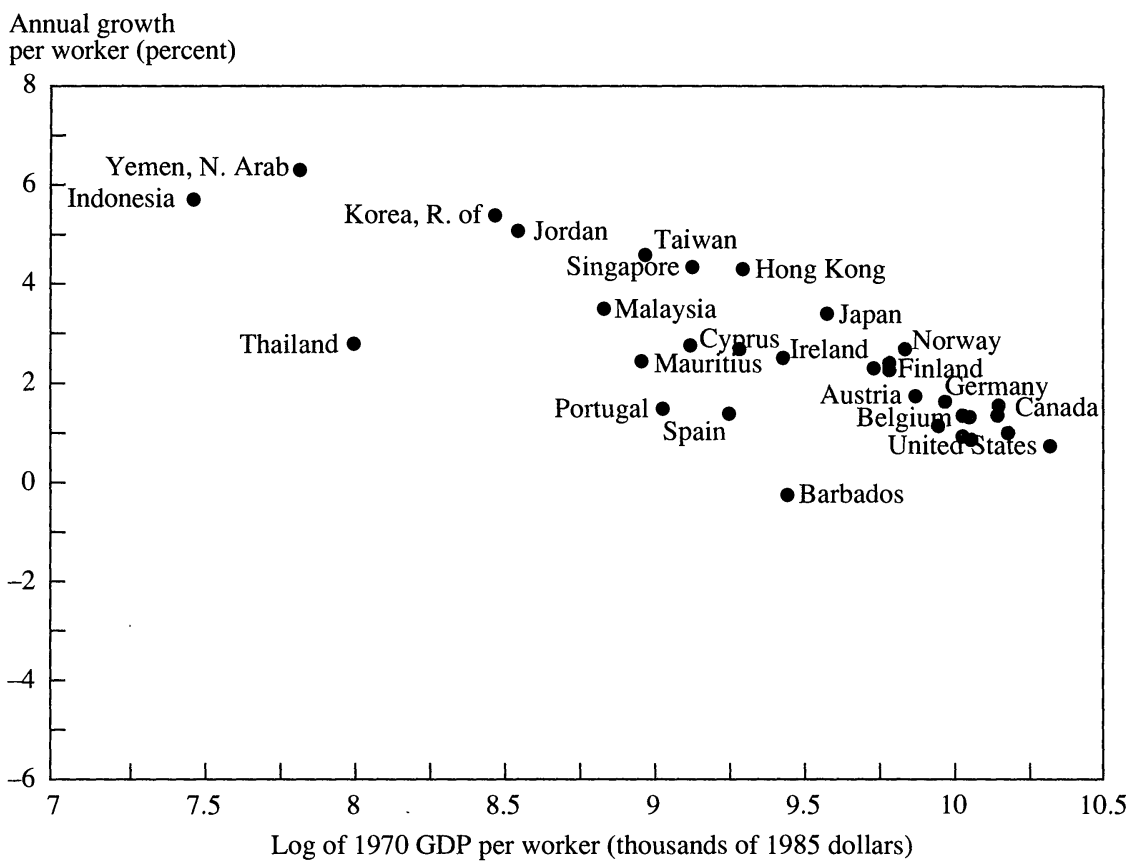

Source: Authors' calculations using versions 5 and 5.5 of the data in Summers and Heston (1991).

growth rate of the open group would be about 0 percent rather than 1.2 percent. We plan to examine this phenomenon further when data from the 1990 census rounds become available.

In summary, we find no cases to support the frequent worry that a country might open and yet fail to grow. Of course, economic reforms take time to work, so that some countries that adopted outward-oriented market reforms in the late 1980 s or early 1990 s might not yet be enjoying high growth rates as a result. We return to the growth effects of recent reforms in the next major section of the paper.

We also find little support for the idea that our results might come from reverse causality or from sample selection bias. We simply find very few examples of developing countries that started open, performed poorly, and closed as a result. The far more common case is that developing countries started closed, performed poorly, and then opened. As 
emphasized above, most developing countries started out as closed economies. And the few that had temporary episodes of liberalization had high growth during the open period. It is therefore hard to argue that slow growth caused the turn to closed policies. Rather, it seems that for reasons unrelated to growth performance, the developing world in 1970 was sorted into a large group of closed economies and a much smaller group of open economies. Twenty-five years later, sufficient time has passed for us to see the effects of this fundamental policy choice on growth.

Our evidence so far suggests that being open to international trade has been sufficient to achieve growth in excess of 2 percent for developing countries. ${ }^{61}$ What of necessity? Are there many countries that closed and yet achieved high economic growth? There are four developing countries that are classified as closed during the period and yet had per capita growth of more than 3 percent per year during 1970-89: Botswana, China, Hungary, and Tunisia.

Botswana failed to qualify on the basis of its black market premium for the 1970s, but did qualify for the 1980s. It passed all other criteria. Overall, therefore, the policies have been relatively open, especially in the 1980s. Moreover, since around 80 percent of Botswana's exports are diamonds, and a remarkably small proportion (less than 5 percent) of the labor force is in agriculture, Botswana avoided the anti-agricultural biases that affected most of sub-Saharan Africa.

It is relatively straightforward to account for Hungary and Tunisia. Their successful growth is more apparent than real. Both countries pursued statist development strategies that produced growth in the 1970s and financial crises in the 1980s and early 1990s. In both cases there was a serious downturn in growth at the end of the 1980s, as these financial crises hit the government. Considered over a slightly longer time period, these countries would not look like successes, and therefore would not be anomalous.

In our view, China is the only puzzle, although it is essentially consistent with the importance of open trade. It is indeed true that China has violated most of the rules: high black market premiums on the yuan, ex-

61. Of course, our indicators of openness are associated with other market-based reform policies, which makes it difficult to identify the precise contribution of trade as compared to other policies. A more precise statement is that open policies together with other correlated policies were sufficient for growth in excess of 2 percent during 1970-89. 
tensive reliance on trade quotas, and a socialist ownership structure. Nonetheless, the country has experienced a boom. We believe that China's success is strongly related to its particular economic structure at the onset of its market reforms at the end of the 1970s.

In particular, China was a very poor economy in 1978, with threequarters of the labor force in peasant farming. The essence of Deng Xiaoping's reforms at the end of the 1970s was to free the peasant economy from state controls, even while maintaining the state's grip on the nonpeasant, state-owned sector (which covered just 18 percent of the labor force). With respect to international trade, the economy was essentially liberalized for nonstate firms, especially those operating in the Special Economic Zones (SEZ) in the coastal areas. Even though the currency remained inconvertible, and many state enterprises remained subject to rationing of imports, the nonstate enterprises (including joint ventures and foreign firms) were generally able to import their inputs nearly duty free, and to export processed goods to world markets. The result was a remarkable export boom, based heavily on labor-intensive operations. Shang-Jin Wei presents clear evidence that trade liberalization played an important role in China's growth. ${ }^{62}$

Thus, China's "two-track approach" (decontrol of the peasant sector and continued control of the state sector) was sufficient to unleash economic development and a labor-intensive export boom, even though it did not solve the many problems of poor performance in the state-owned sector. Some analysts have also argued that its boom is fragile and could still be stopped by the macroeconomic instability characteristic of many economies part way between planning and a market economy. ${ }^{63}$

We now turn briefly to a regression analysis, to confirm and deepen these basic findings. Various regression estimates are reported in table 11 , showing the relationship between initial income in 1970 and subsequent growth between 1970 and 1989. We see in regression 1 the absence

62. To quote his conclusions: "I have found some clear evidence that during 1980-90 more exports are positively associated with higher growth rates across Chinese cities. In the late 1980s, the contribution to growth comes mainly from foreign investment. Furthermore, the contribution of foreign investment comes in the form of technological or managerial spillovers across firms as opposed to an infusion of new capital. Finally, the superb growth rates of coastal areas relative to the national average can be entirely explained by their effective use of exports and foreign investment." (Wei, 1995, p. 74.) Also, see Lardy (1994) for further discussion of China's recent experience with international trade.

63. See Sachs and Woo (1994) for further details of the two-track approach in China and the current macroeconomic problems. 
of convergence for the entire sample of countries (the coefficient on initial income is positive rather than negative, and is statistically insignificant). In regression 2 we see the strong evidence of convergence within the set of open countries. The coefficient on initial income suggests that each percentage point rise in per capita income in 1970 reduces subsequent annual growth by 0.014 percentage points. Each doubling of 1970 income reduces annual growth by 0.95 percentage points $(=\ln (2) \times$ 1.368). In regression 3 , we confirm the absence of convergence among the nonqualifying countries.

We have also found that this result on the importance of openness for growth is robust to the presence of several other possible explanatory variables. In regressions 4 and 5 we illustrate this with Barro's growth regression, since it is particularly well known. ${ }^{64}$ In regression 4 , we replicate the Barro regression on cross-country growth for our sample and time period. We see it performs as expected, showing conditional convergence (a negative, significant coefficient on initial income), positive (although not significant) effects of educational attainment, positive effects of the investment-to-GDP ratio, and negative effects of measures of political instability.

Regression 5 estimates the same equation but includes a dummy variable for openness (OPEN $=0$ for a closed economy, 1 for an open economy). When we add $O P E N$, we find that the open economies grow, on average, by 2.45 percentage points more than the closed economies, with a highly statistically significant effect. Comparing the rest of the regressors with the estimates of regression 4 , the effect of investment declines and the initial education levels are even less significant. This is consistent with our view that the growth rate over this period was determined less by initial human capital levels than by policy choices. Our finding that openness plays an important role in a Barro-style crosscountry growth equation is consistent with much recent research, including work by Surgit Bhalla, J. Bradford De Long and Lawrence Summers, David Dollar, and Ross Levine and David Renelt. ${ }^{65}$ Indeed, some

64. See Barro (1991).

65. See Bhalla (1994), De Long and Summers (1991), Dollar (1992), and Levine and Renelt (1992). More specifically, De Long and Summers use several measures of outward orientation and price distortions. Levine and Renelt use the black market premium, the number of revolutions and coups, a socialist dummy, a civil liberties index, and measures of openness based on Leamer (1988). These studies examine the marginal contribution of the variables on the right side of a regression equation; none use these variables to sort countries into groups and examine the groups separately. 


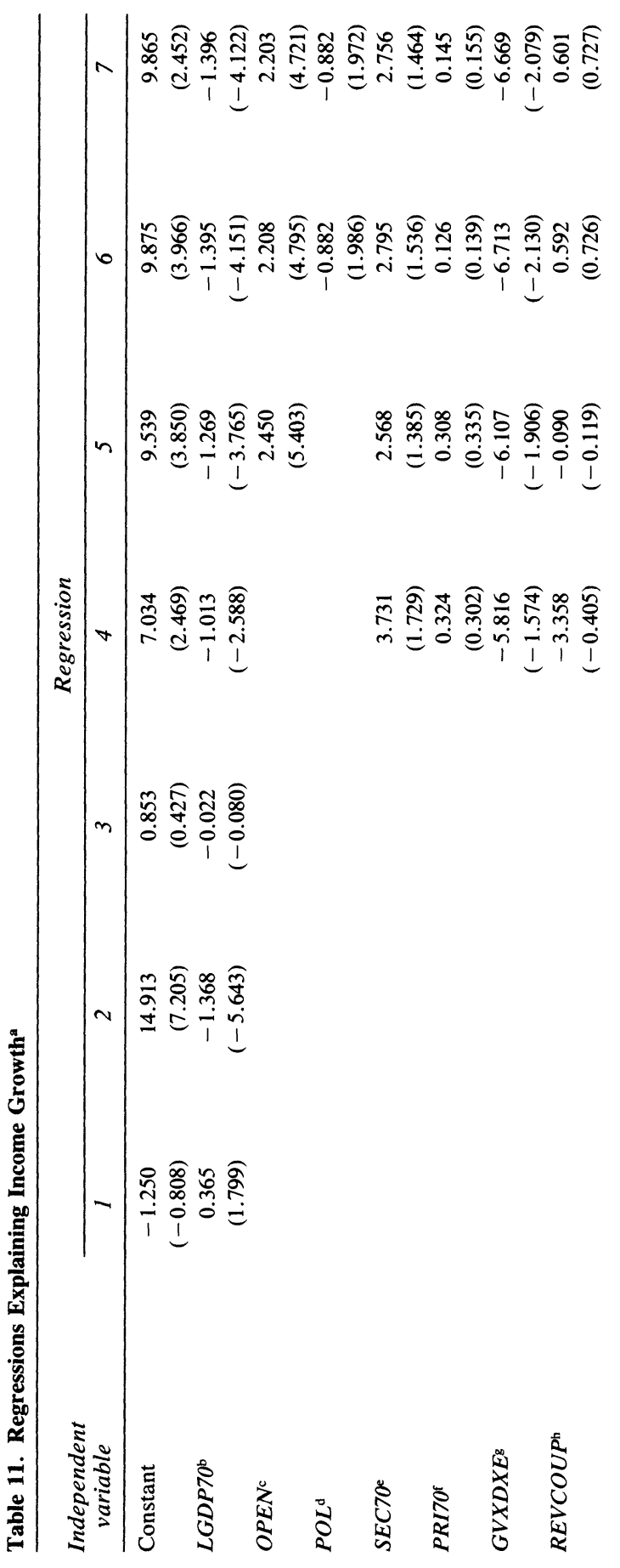




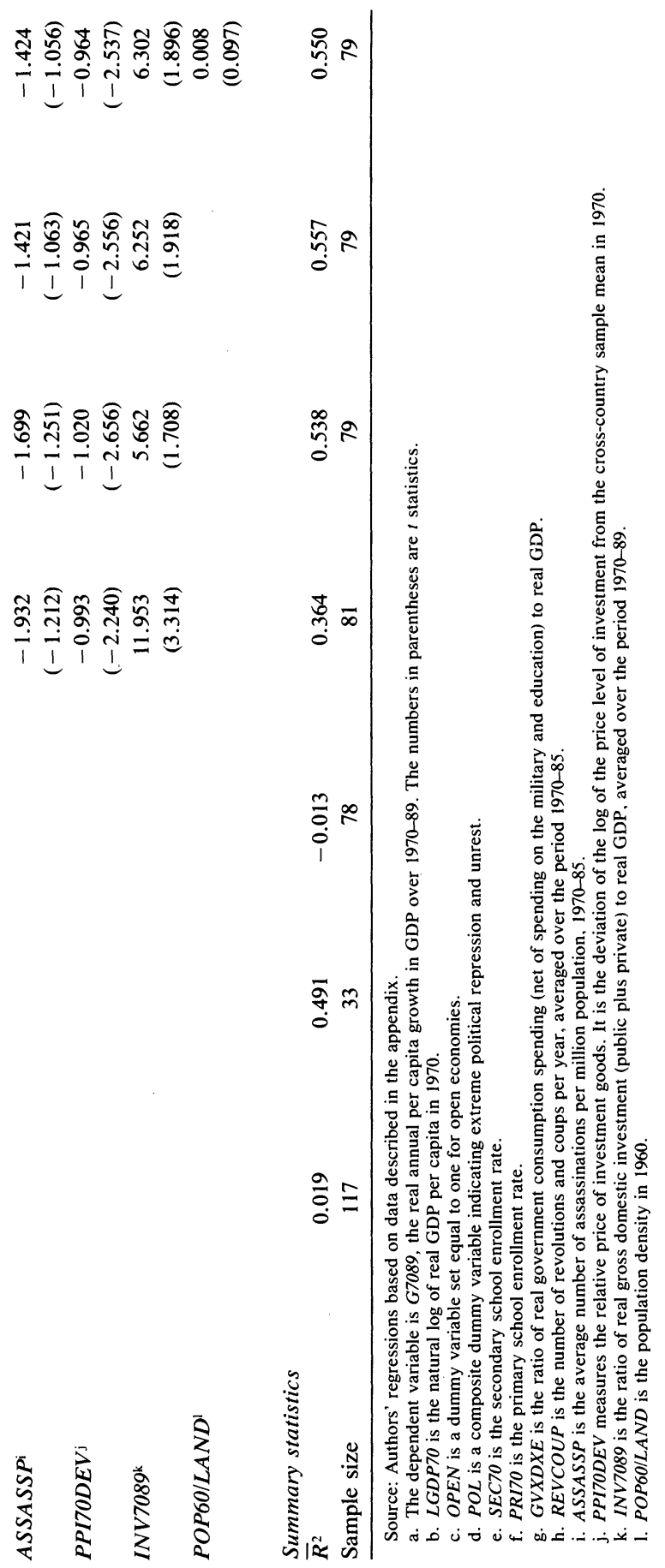


of our data, such as the tariff and black market premium data, have been used in previous studies, including those by Jong-Wha Lee and Levine and Renelt. ${ }^{66}$ Our treatment of these data differs from the earlier studies in two important ways: first, by our construction of a single indicator measure of openness (built on several underlying variables); and second, by our examination of growth performance within the subset of open economies, as well as between closed and open economies. To our knowledge, no earlier studies have pointed out that corıvergence applies to the worldwide subset of open economies. ${ }^{67}$

In regression 6 , we add a dummy variable, $P O L$, to account for extreme political conditions detrimental to long-term investment. The variable POL takes a value of 1 when any of the following conditions applies:

-A socialist economic structure, according to the list of countries compiled by Kornai. ${ }^{68}$

-Extreme domestic unrest caused by revolutions, coups, chronic civil unrest, or a prolonged war with a foreign country that is fought on domestic territory.

-Extreme deprivation of civil and political rights, according to the Freedom House index reported by McMillan, Rausser, and Johnson. ${ }^{69}$

We see that the $P O L$ variable is statistically significant at the 10 percent level $(t=1.986)$, suggesting that property rights, freedom, and safety from violence are additional determinants of growth.$^{70}$ This finding is in accord with other recent studies, including work by A. S. Alesina and others, Barro, Bhalla, and Jakob Svensson. ${ }^{71}$ In other regressions, not reported here, we have experimented with the three individual items in the $P O L$ index, and have found that each one plays a role in the growth process.

66. See Lee (1993) and Levine and Renelt (1992).

67. Note also that we find no evidence for significant interactions between the openness variable and the other regressors that would diminish the explanatory power of openness.

68. Kornai (1992).

69. McMillan, Rausser, and Johnson (1994).

70. Note, however, that the set of countries with $P O L=1$ is a subset of the set of closed economies. Therefore use of the $P O L$ variable as an additional criterion to classify countries would give the same set of countries as using the $O P E N$ variable alone. The same is true for the set of countries that had annual inflation rates above 100 percent for any year between 1970 and 1989.

71. See Alesina and others (1992), Barro (1991), Bhalla (1994), and Svensson (1994). 
Table 12. Effects of Growth on Human and Physical Capital Accumulation ${ }^{\mathrm{a}}$

\begin{tabular}{lccc}
\hline \multirow{2}{*}{$\begin{array}{l}\text { Independent } \\
\text { variable }\end{array}$} & \multicolumn{3}{c}{ Dependent variable } \\
\cline { 2 - 4 } & INV7089 & $D S Y R^{\mathrm{b}}$ & $D P Y R^{\mathrm{d}}$ \\
\hline Constant & -0.144 & 0.118 & 0.151 \\
& $(-2.232)$ & $(3.144)$ & $(4.566)$ \\
OPEN $^{\mathrm{e}}$ & 0.054 & -0.004 & -0.003 \\
& $(3.328)$ & $(-0.502)$ & $(-0.360)$ \\
LGDP70 $^{\mathrm{f}}$ & 0.047 & -0.010 & -0.016 \\
& $(6.412)$ & $(-2.137)$ & $(-4.283)$ \\
$\bar{S}^{2}$ & & & \\
Meanmary statistics & 0.519 & 0.069 & 0.250 \\
SER & 0.182 & 0.049 & 0.025 \\
Sample size & 0.063 & 0.033 & 0.027 \\
\hline
\end{tabular}

Source: Authors' regressions based on data described in the appendix.

a. The numbers in parentheses are $t$ statistics.

b. IN7089 is the ratio of public and private investment spending to GDP, averaged over the period 1970-89.

c. $D S Y R$ is average accumulation of secondary schooling over the period 1970-85. Specifically, DSYR = [ $\ln (S Y R 85)-\ln (S Y R 70) / 15]$, where $S Y R x x$ is person years of secondary schooling divided by the total population over age fifteen.

d. DPYR is accumulation of primary schooling, calculated in the same manner as DSYR.

e. OPEN is a dummy variable set equal to one for open economies.

f. $L G D P 70$ is the natural $\log$ of GDP per capita in 1970.

We have shown above that the labor-to-land ratio has been a determinant of the timing of liberalization among developing countries. In regression 7 we include this ratio as a possible independent determinant of growth, to check whether openness is acting simply as a proxy for relative factor endowments. The variable is insignificant, while the openness variable maintains its magnitude and statistical significance.

We have found strong evidence that protectionist trade policies reduce overall growth when controlling for the other variables. Since poor trade policies might also affect the rates of investment relative to GDP and the rates of human capital accumulation, we would expect poor policies to have indirect adverse growth effects as a result of slower accumulation of capital, both physical and human. In regressions 8-10 in table 12 , we therefore check whether open and closed economies differed systematically in the rates of capital accumulation, once we control for initial income. In regression 8 we find that the open economies had significantly higher investment-to-GDP ratios, and that $O P E N$ raised the investment ratio by an average of 5.4 percentage points. ${ }^{72}$ Interestingly,

72. Levine and Renelt (1992), using trade shares as a measure of openness, also find that investment shares are higher in more open economies. This is one of the few findings that they classify as robust, using extreme bounds analysis. 
there is also some evidence that richer countries have higher investment rates than poorer countries.

In regressions 9 and 10, we ask whether the increase in educational attainment between 1970 and 1985 was different for the two subsets of countries. We find no evidence that the closed economies had less improvement in the coverage of primary and secondary education than did the open economies. It is clear, though, that the more developed economies had less improvement in educational coverage than did the poorer countries (as evidenced by the significant negative sign on initial income in both regressions).

Based on the regression analysis, we may make four conclusions:

- There is strong evidence of unconditional convergence for open countries, and no evidence of unconditional convergence for closed countries. ${ }^{73}$

- Closed countries systematically grow more slowly than do open countries, showing that "good" policies matter.

- The role of trade policy continues after controlling for other growth factors, as in a standard Barro cross-country growth equation.

- Poor trade policies seem to affect growth directly, controlling for other factors, and to affect the rate of accumulation of physical capital.

\section{Trade Policy and Changes in the Export Structure}

One of the original arguments for SLI was the promotion of manufacturing exports. Raul Prebisch and other economists worried that raw materials exporters that maintained free trade would be unable to industrialize, and would therefore be vulnerable to long-term adverse movements in the terms of trade between primary and manufactured goods. Import substitution, it was argued, would give time for domestic industry to develop and to improve productivity, perhaps sufficient to generate manufactured exports in the distant future. Paul Krugman gave an influential exposition of this infant-industry argument in a formal model of increasing-returns-to-scale production resulting from learning by doing. ${ }^{74}$

73. An alternative, and formally equivalent, way to state our conclusion is that convergence is conditional on policies, not on structural variables (for example, initial income or level of education). We therefore argue against the notion of a low-income "development trap," since open trade policies (and correlated market policies) are available to even the poorest countries.

74. Krugman (1987). 
Using our classification of trade policy, we can examine the two related propositions that open trade condemns raw materials exporters to nonindustrialization, and that closed trade promotes industrial exports in the long term. Based on UNCTAD classifications of trade structure, we measure the share of primary exports (agriculture, minerals, fuels, and metals) in total merchandise exports, $X$. We then examine the change in $X$ between 1971 and 1989 as a function of trade policy during the period.

Our basic model is:

$$
X_{i}^{89}-X_{i}^{71}=\left(\beta+\gamma O P E N_{i}\right) \times\left(X_{i}^{L T}-X_{i}^{71}\right) .
$$

According to equation 4, the share of primary exports in GDP adjusts gradually to a long-term equilibrium level denoted $X_{i}^{L T}$. This long-term level may itself be a function of the specific factor endowments of the country, for example the ratio of labor to land and other natural resources, as well as the long-term structure of trade policy itself. The degree of openness, in turn, may affect the speed of adjustment. If the parameter $\gamma$ is positive, open economies adjust more rapidly to their longterm equilibrium, while if $\gamma$ is negative, closed economies adjust more rapidly to their long-term equilibrium, $X_{i}^{L T}$. According to the theory of import protection as export promotion, a primary exporter that is evolving toward being a manufacturing exporter will experience a faster transition to manufacturing exports with a protective trade policy (that is, $\gamma<0$ ).

We estimate equation 4 , with the addition of a constant term, $\theta$, in four variants. In the first regression shown in table 13, we assume that the long-term level of $X$ is the same for all economies, and that the export structure gradually adjusts to that common long-run value. Our point estimate of the long-run value of $X$ is not significantly different from zero (that is, no exports of primary goods in the long run). We find that closed economies have a partial adjustment coefficient of only 0.049 , while open economies have a coefficient of 0.366 (equal to $0.049+0.317$ ). Thus open economies tend to adjust more rapidly from being primaryintensive to manufactures-intensive exporters. The difference in speed of adjustment is statistically significant. While many countries adopted the model of import protection as export promotion (of manufactures), it was the open economies that did best in promoting the export of manufactures. 
Table 13. Openness and Export Diversity in Developing Countries ${ }^{\mathrm{a}}$

\begin{tabular}{|c|c|c|c|c|}
\hline \multirow{2}{*}{$\begin{array}{l}\text { Estimated } \\
\text { parameter }\end{array}$} & \multicolumn{4}{|c|}{ Regression } \\
\hline & 1 & 2 & 3 & 4 \\
\hline$\theta$ & $\begin{array}{c}-0.035 \\
(-0.377)\end{array}$ & $\begin{array}{c}-0.044 \\
(-0.397)\end{array}$ & $\begin{array}{c}-0.044 \\
(-0.397)\end{array}$ & $\begin{array}{c}-0.044 \\
(-0.902)\end{array}$ \\
\hline$\beta$ & $\begin{array}{c}0.049 \\
(0.491)\end{array}$ & $\begin{array}{c}0.034 \\
(0.315)\end{array}$ & $\begin{array}{c}0.034 \\
(0.315)\end{array}$ & $\begin{array}{c}0.036 \\
(0.413)\end{array}$ \\
\hline$\gamma$ & $\begin{array}{c}0.317 \\
(1.987)\end{array}$ & $\begin{array}{c}0.286 \\
(1.408)\end{array}$ & $\begin{array}{c}0.286 \\
(1.408)\end{array}$ & $\begin{array}{c}0.318 \\
(2.535)\end{array}$ \\
\hline$\alpha$ & $\begin{array}{c}-0.035 \\
(-0.097)\end{array}$ & $\begin{array}{c}0.055 \\
(0.092)\end{array}$ & $\begin{array}{c}0.055 \\
(0.092)\end{array}$ & $\begin{array}{c}0.078 \\
(0.035)\end{array}$ \\
\hline$\delta$ & & $\begin{array}{c}-0.077 \\
(-0.339)\end{array}$ & $\begin{array}{c}-0.077 \\
(-0.339)\end{array}$ & $\begin{array}{r}-0.0013 \\
(-0.058)\end{array}$ \\
\hline$\epsilon$ & & & $\begin{array}{l}-0.000004 \\
(-0.000)\end{array}$ & $\begin{array}{c}-0.272 \\
(-0.123)\end{array}$ \\
\hline \multicolumn{5}{|l|}{ Summary statistics } \\
\hline $\bar{R}^{2}$ & 0.165 & 0.162 & 0.162 & 0.129 \\
\hline Mean dependent variable & -0.101 & -0.103 & -0.103 & -0.094 \\
\hline SER & 0.160 & 0.161 & 0.161 & 0.151 \\
\hline Sample size & 80 & 78 & 78 & 99 \\
\hline
\end{tabular}

Source: Authors' regression based on data described in the appendix.

a. The regressions are from equation 4 in the text, $X^{89}-X^{71}=\theta+(\beta+\gamma$ OPEN $)(\alpha+\delta$ POPL $+\epsilon$ OPEN $-\mathrm{X}^{71}$ ). OPEN is a dummy variable set equal to one for open economies. POPL is the ratio of population to land area in $1960 . X^{71}$ and $X^{89}$ are the fraction of primary exports in total exports in 1971 and 1989. The numbers in parentheses are $t$ statistics.

The next two variants of the regression investigate whether the landto-labor ratio and the trade policy affect the long-term levels of $X$. In the second regression, we assume that $X$ is a negative function of the endowment of population $(P O P)$ relative to land area $(L)$. Economies with a high population-to-land area ratio would be expected to have a low value of $X$, so if $X_{i}^{L T}=\alpha+\delta(P O P / L)_{i}$, we expect $\delta<0$. In the third equation in table 13 we assume that the measure of trade policy during 1970-90 $(O P E N=0$ or 1$)$ is also a measure of long-run trade policy (or the market's expectation of long-run trade policy), and is therefore a determinant of the long-run value of $X$, so that $X_{i}^{L T}=\alpha+\delta\left(P O P / L_{i j}\right)+\epsilon O P E N_{i}$.

As table 13 shows, neither the ratio of population to land area nor openness is a statistically significant determinant of the long-run proportion of primary exports. In fact, the estimated $X^{L T}$ is virtually unaffected by the inclusion of the other variables. The important result is that the speed of adjustment is still different in closed and open economies. Open economies continue to display much greater dynamism in changing their export structure from primary commodities to manufactures. Indeed, 
closed economies display almost no change at all in export structure during the nearly-twenty-year interval examined in the regressions, since the estimate of $\beta$ is always insignificant. In regression 4 we show that these conclusions also hold when the regression is estimated with the developed countries added to the sample.

\section{Trade Policy and Macroeconomic Crises}

Jeffrey Sachs argued in 1985 that the outward orientation of the East Asian economies had saved them from the developing country debt crisis that ravaged Latin America. ${ }^{75}$ Now, ten years later, it is possible to reassess his hypothesis with a greater time span and a larger number of country observations. Is there evidence that openness to trade helped to avoid macroeconomic crises in the 1980s? To address this issue we classify countries according to their trade orientation in the 1970s and then examine whether the countries that were open in the 1970s were less likely to experience a severe macroeconomic crisis in the 1980s and 1990s. For these purposes, we define a severe macroeconomic crisis by any one of the following three occurrences:

-A rescheduling of foreign debt in the Paris Club (official creditors) or the London Club (commercial bank creditors).

- Arrears on external payments (including debt servicing), as reported by the IMF.

-An inflation rate in excess of 100 percent per year.

We expect that closed economies will be more likely than open economies to fall into one or more of these crises, for several related reasons. First, and most important, closed economies often borrowed heavily from foreign sources in order to overcome economic stagnation caused by the deeper problem of poor economic policies. ${ }^{76}$ The reliance on debt was a temporary expedient, and resulted in a debt crisis when creditors withdrew support from further lending. Second, closed economies oriented investment toward nontraded goods, and thus lacked the foreign exchange earnings to service the debts. Third, closed economies tended to have a higher level of state involvement in the economy, including the ownership of state enterprises. Loss-making state enterprises added significantly to the overall fiscal burden of many governments in the 1980s, contributing to the onset of high inflation and foreign debt crises.

75. Sachs (1985).

76. See Sachs (1994). 
Table 14. Developing Country Openness and Macroeconomic Crisis ${ }^{a}$

\begin{tabular}{lcc}
\hline Openness & $\begin{array}{c}\text { Macroeconomic } \\
\text { crisis in 1980s }\end{array}$ & $\begin{array}{c}\text { No macroeconomic } \\
\text { crisis in 1980s }\end{array}$ \\
\hline Open in 1970s & 1 & 16 \\
Not open in 1970s & 59 & 14 \\
\hline
\end{tabular}

Source: See appendix.

a. In a test of independence the chi square is 34.8 (significance level $<0.000$ ).

There are seventeen developing countries that had an open trade policy in the 1970s. Of these, only Jordan succumbed to a macroeconomic crisis after opening: debt reschedulings in 1987 and 1992, and external payments arrears in 1993. The first episode of macroeconomic difficulties followed a sharp cutback in foreign aid from the oil-rich states of the region as a result of the collapse of world oil prices in 1986. Following the 1990 Gulf War, Jordan experienced a more serious macroeconomic shock, which cost it heavily in remittance and export earnings.

There were seventy-three closed developing countries in the 1970s. Of these, as many as fifty-nine experienced a severe macroeconomic crisis: forty-nine had a debt crisis; fifty had external payments arrears; and nineteen had inflation above 100 percent (most manifested more than one of these crises). Table 14 summarizes the relative frequencies of openness and macroeconomic crisis. A $\chi^{2}$ test on the null hypothesis of independence between trade policy in the 1970s and macroeconomic crisis in the 1980 s is rejected at the 0.000 level.

Rather than focus on the large majority of countries that succumbed to crisis, it is easier to assess the fourteen that did not: Bangladesh, Botswana, Burundi, China, Colombia, Hungary, India, Iran, Nepal, Papua New Guinea, Rwanda, Sri Lanka, Tunisia, and Zimbabwe. Of these, Botswana had opened its economy by 1979; Colombia maintained very cautious and moderate policies both in trade and in finance; both Hungary and India, in fact, flirted with a debt crisis which was narrowly averted; China began the 1980s with very little debt because it had borrowed little during the Cultural Revolution of 1966-76; Bangladesh, Burundi, Nepal, and Rwanda are among the world's poorest countries and have little, if any, access to loans on commercial terms, which has probably saved them from generating a debt crisis. Moreover, Burundi and Rwanda have been subject to extreme internal unrest. 


\section{Recent Reforms and Economic Performance}

The previous section compared countries with long-standing policies of open trade during the nineteen-year period 1970-89, with countries that were closed during some or all of the period. In this section, we examine the growth effects of trade liberalization in developing countries that have opened their economies since 1975 . By our assessment, there are thirty-eight non-communist reformers that have opened their economies since 1975 and sustained the opening until 1993. Venezuela attempted trade liberalization between 1989 and 1992, but the policy was then reversed. Another thirty-six countries in our sample did not even achieve a temporary liberalization during 1980-93. In addition to this group of countries, we also examine the recent growth performance of the twenty-five post-communist economies of eastern Europe and the former Soviet Union, to see how growth performance relates to trade reform and overall economic reform.

Here, we stress again that trade reform is almost always accompanied by a much broader range of reforms, including macroeconomic stabilization, internal liberalization (for example, the end of price controls), legal reform, and often extensive privatization. This has been especially clear in the post-communist countries. In almost all cases, trade reform has been part of the overall institutional harmonization with the advanced market economies. Our results cannot, therefore, distinguish between the effects of trade policy per se, and the effects of other parts of the policy package that accompany the trade measures. While we view the direct effects of trade liberalization (increased competition, specialization, and reduced rent-seeking) as important contributory factors for growth, we put off attempting to tease out the specific contributions to growth of the various parts of a standard reform program until a future study.

We note also that the very-short-term growth consequences of a trade reform will depend importantly on the inherited structure of the economy. In the post-communist countries of eastern Europe and the former Soviet Union, the long period of central planning left the economy with an enormously overgrown heavy industrial sector, evident, for example, in the high levels of coal and steel production relative to the rest of 
output. In those economies, therefore, the end of central planning (and the sharp drop in armaments production in the former Soviet Union) resulted initially in a significant drop of industrial output. This was true throughout the region, independent of the specific nature of a reform program. In the East Asian communist economies, by contrast, the industrial sector was much smaller at the start of reforms, so they did not experience a drop in industrial production when trade and other market reforms were first introduced. ${ }^{77}$

Table 15 examines the economic growth of recent developing country reformers by comparing the annual growth for country $i$ in four intervals: $I_{1}=[T-10, T-4], I_{2}=[T-3, T-1], I_{3}=[T, T+2]$, and $I_{4}=[T+3, N]$, where $N$ is either $[T+10]$ or the latest year for which data are available (usually 1993), whichever is earlier. $T$ is the year of trade liberalization, that is, the year in which trade policy first satisfies the five criteria for openness described above. By estimating the following regression model, we test whether growth is higher or lower on average after the onset of open trade:

$$
G_{i t}=\alpha_{i}+\gamma_{2} D_{2 t}+\gamma_{3} D_{3 t}+\gamma_{4} D_{4 t}+\epsilon_{i t},
$$

where $D_{j t}=1$ for $t$ belonging to $I_{j}$ and $D_{j t}=0$ otherwise. This equation allows for a separate fixed effect on growth for country $i$, plus a timing effect for intervals 2, 3, and 4. The error term, $\epsilon_{i t}$, is an (i.i.d.) random variable. If trade liberalization raises growth relative to the "distant past" (years $[T-10]$ through $[T-4]$ ), then $\gamma_{3}$ and $\gamma_{4}$ should be positive. If trade liberalization raises growth relative to the "recent past" (years $[T-3]$ through $[T-1])$, then $\left(\gamma_{3}-\gamma_{2}\right)$ and $\left(\gamma_{4}-\gamma_{2}\right)$ will be positive. If trade reform is initially contractionary, and subsequently expansionary, we would find $\gamma_{3}<0$ and $\gamma_{4}>0$.

The estimated coefficients are as follows, with $t$ statistics in parentheses below:

$$
\begin{gathered}
\left.G_{i t}=\alpha_{i}-(0.88) D_{2 t}+(1.09) D_{3 t}+(1.33) D_{4 t}\right)+\epsilon_{i t} . \\
(-1.66)
\end{gathered}
$$

According to these results, economic growth is indeed higher after trade liberalization than in the distant past, both in the near term $[T, T+2]$,

77. See Sachs and Woo (1993) and Sachs (1995c) for comparisons of eastern Europe and East Asia. 
Table 15. Real Per Capita Growth Rates of the Recent Reformers ${ }^{a}$

Annual averages over subperiods (percent)

\begin{tabular}{|c|c|c|c|c|c|}
\hline Country & $\begin{array}{l}\text { Reform } \\
\text { year }\end{array}$ & $t \in[-10,-4]$ & $t \in[-3,-1]$ & $t \in[0,2]$ & $t \in[3, n]$ \\
\hline Argentina & 1991 & -0.10 & -3.83 & 6.55 & \\
\hline Benin & 1990 & 0.25 & -3.25 & 0.91 & 0.38 \\
\hline Bolivia & 1985 & -1.78 & -5.06 & -2.88 & 1.14 \\
\hline Botswana & 1979 & 13.96 & 9.87 & 7.31 & 5.31 \\
\hline Brazil & 1991 & 4.08 & -2.32 & -0.08 & \\
\hline Cameroon & 1993 & -3.47 & -9.17 & -7.68 & \\
\hline Chile & 1976 & 1.20 & -6.21 & 4.98 & 3.44 \\
\hline Colombia & 1991 & 2.54 & 2.03 & 1.91 & \\
\hline Costa Rica & 1986 & -3.80 & 0.87 & 1.64 & 2.45 \\
\hline Ecuador & 1991 & -1.36 & 2.05 & 1.34 & \\
\hline El Salvador & 1989 & -0.93 & 0.29 & 0.60 & 2.83 \\
\hline Gambia & 1985 & -0.61 & -0.14 & -1.37 & -0.12 \\
\hline Ghana & 1985 & -0.55 & -3.93 & 1.31 & 1.37 \\
\hline Guatemala & 1988 & -3.97 & -1.83 & 0.69 & 1.21 \\
\hline Guinea & 1986 & & & 1.40 & 0.58 \\
\hline Guinea-Bissau & 1987 & -1.87 & 1.15 & 3.63 & 0.74 \\
\hline Guyana & 1988 & -5.40 & -0.69 & -4.50 & 6.89 \\
\hline Honduras & 1991 & 0.43 & -0.08 & 1.15 & \\
\hline India & 1994 & 2.97 & 4.90 & 1.00 & \\
\hline Israel & 1985 & 3.41 & 0.38 & 3.43 & 1.41 \\
\hline Jamaica & 1988 & -0.10 & 0.25 & 3.22 & 0.27 \\
\hline Kenya & 1993 & 2.66 & -1.20 & -1.66 & \\
\hline Mali & 1988 & -2.15 & 3.21 & 0.74 & 0.03 \\
\hline Mexico & 1986 & 3.93 & -1.34 & -1.98 & 1.03 \\
\hline Morocco & 1984 & 3.01 & -0.46 & 3.23 & -0.00 \\
\hline Nepal & 1991 & 3.35 & 3.94 & 0.62 & \\
\hline Nicaragua & 1991 & -4.45 & -6.25 & -2.84 & \\
\hline Paraguay & 1991 & -0.27 & 2.13 & -0.21 & \\
\hline Peru & 1991 & 4.09 & -9.68 & 0.35 & \\
\hline Philippines & 1988 & -2.09 & -2.23 & 2.81 & -1.80 \\
\hline South Africa & 1991 & -1.05 & -0.39 & -2.73 & \\
\hline Sri Lanka & 1991 & 2.31 & 2.41 & 3.90 & \\
\hline Tunisia & 1989 & 1.28 & -0.45 & 2.95 & 3.02 \\
\hline Turkey & 1989 & -0.71 & 4.16 & 1.67 & 3.57 \\
\hline Uganda & 1988 & -6.58 & 0.25 & 3.00 & 0.96 \\
\hline Uruguay & 1990 & -0.96 & 2.56 & 3.19 & 0.57 \\
\hline Zambia & 1993 & -1.12 & -3.90 & 3.65 & \\
\hline \multicolumn{6}{|l|}{ Summary statistics } \\
\hline Unweighted average & & 0.130 & -0.718 & 1.297 & 1.965 \\
\hline Standard deviation & & $(5.604)$ & $(5.347)$ & (3.417) & (3.526) \\
\hline
\end{tabular}

Source: These growth rates are based on real GDP and population data from the World Bank (1994d). When possible, these data are supplemented with data from national sources.

a. The sample of thirty-seven countries corresponds to the thirty-six countries that opened after 1975, from table 2 , and Israel, from table 3 . 
by an average of 1.09 percentage points per year, and in the more distant future $[T+3, N]$, by an average of 1.33 percentage points per year. ${ }^{78}$ The near-term gain is significant at $(p=0.10)$, while the longterm gain is statistically significant at $(p=0.05)$. The increase in average growth is larger when compared with the years immediately preceding the trade liberalization, since average growth rates are lower in those years than in the years $[T-10]$ through [T - 3] (by 0.88 percent per year on average). ${ }^{79}$

\section{Trade Liberalization and Growth in Transition Economies}

The countries of central and eastern Europe have been undertaking market reforms, including trade liberalization, since 1990, while the countries of the former Soviet Union have been undertaking market reforms since 1992. It is obviously extremely premature to draw strong conclusions regarding the effects of these reforms on the restoration of economic growth. Nonetheless, at least some evidence can be adduced from the five or more years of reform experienced by some parts of the region.

78. Other statistics for the regression are the number of observations, $N=548$, adjusted $R^{2}=0.149$; and the $F$ statistic for the overall regression, $F=3.45(p<0.001)$. The only country dummy that is statistically significant is Botswana, with a dummy variable of $8.14, t=4.585$.

79. It is worthwhile responding to two possible criticisms of these results. First, it could be objected that if growth outcomes were purely random, and countries reformed only when growth fell below a critical threshold, then although we would tend to observe higher growth after reform, it would be incorrect to attribute the higher growth to the reform. However, we stress that we are comparing growth after the reforms with growth in the distant rather than the immediate past, and further, that our period for the distant past spans seven years.

Second, it is possible that countries may have sorted themselves randomly as reformers and nonreformers. If some grew and others did not, and those that did not closed up again and thus were eliminated from our group of reformers, we would be left with a biased sample of reformers with high growth. But we have found few examples of countries that experienced slow growth after true reform. For example, economies that were temporarily open in the 1950s and 1960s and subsequently closed again, tended to have high growth rates during the liberal episode. We have also found that certain countries that are sometimes cited as recent reformers, such as the Dominican Republic in the early 1980s and Nigeria between 1986 and 1992, actually did not reform sufficiently (by our criteria), while others that did reform temporarily, such as Venezuela, experienced rapid growth during the episode of liberalization. Hence we find few examples to suggest that sample selection bias is an important issue when examining the growth performance of recent reformers. 
We are aided in this process by a recent review of the reform experience conducted by the European Bank for Reconstruction and Development (EBRD) ${ }^{80}$ The EBRD ranked each country of the region according to the extent of trade liberalization, as well as several other key categories of reform, such as privatization, regulatory reform, and fiscal reform. Using these indicators, it is possible to group the countries by the intensity of reform as well as the timing of its onset, as we do in table 16. The intensity of reform is measured on a scale from 1 to 4 , with a higher number greater intensity. On the basis of this categorization, we ask two questions: first, whether intensive reformers exhibit more or less decline in cumulative GDP between 1989 and 1994; and second, whether intensive or early reformers enjoy a faster turnaround in economic growth, and thereby achieve positive GDP growth by 1994 .

Table 16 shows that all of the strong trade reformers had achieved positive economic growth by 1994 , while none of the other countries had done so. On average, the strong reformers also experienced a smaller cumulative loss of GDP between 1989 and 1994, though there is considerable variance in the data. We must stress, however, that since all the countries of central and eastern Europe and the Baltic states are classified as strong trade reformers, while none of the states of the former Soviet Union is, we cannot distinguish adequately between the specific role of trade policy and the many other differences (geography, politics, resource endowments) between the two regions that might help to explain the differences in growth performance. At the least we can highlight that the data are consistent with the notion that strong trade reforms have produced a faster turnaround in growth and a smaller cumulative decline. More powerful tests of this hypothesis will have to wait until more time has elapsed.

\section{Conclusions}

The world economy at the end of the twentieth century looks much like the world economy at the end of the nineteenth century. A global capitalist system is taking shape, drawing almost all regions of the world into arrangements of open trade and harmonized economic institutions. As in the nineteenth century, this new round of globalization promises

80. European Bank for Reconstruction and Development (1994). 
Table 16. Growth Rates of the Transition Economies

Percent

\begin{tabular}{lcccc}
\hline Country & $\begin{array}{c}\text { Strength of } \\
\text { trade } \\
\text { reform }\end{array}$ & $\begin{array}{c}\text { Year of } \\
\text { trade } \\
\text { reform }\end{array}$ & $\begin{array}{c}\text { Cumulative } \\
\text { growth } \\
\text { 1989-94 }\end{array}$ & $\begin{array}{c}\text { Growth } \\
1994\end{array}$ \\
\hline Hungary & \multicolumn{4}{c}{ Strong reforms } \\
Poland & 4 & & & \\
Bulgaria & 4 & 1990 & -17.94 & 2.00 \\
Czech Republic & 4 & 1990 & -9.23 & 5.00 \\
Slovak Republic & 4 & 1991 & -26.41 & 1.40 \\
Slovenia & 4 & 1991 & -15.49 & 3.00 \\
Albania & 4 & 1991 & -19.53 & 5.00 \\
Estonia & 4 & 1991 & -13.26 & 5.00 \\
Romania & 4 & 1992 & -22.89 & 7.00 \\
Croatia & 4 & 1992 & -29.15 & 5.00 \\
Latvia & 4 & 1992 & -30.79 & 3.00 \\
Lithuania & 4 & 1993 & -31.04 & 1.00 \\
$\quad$ Average & 4 & 1993 & -39.52 & 3.00 \\
& & 1993 & -55.44 & 2.00 \\
& & & -25.89 & 3.53
\end{tabular}

Kyrgyzstan

Russia

Average

FYR Macedonia

Moldova

Armenia

Kazakhstan

Uzbekistan

Average

Belarus

Azerbaijan

Georgia

Tajikistan

Turkmenistan

Ukraine

Average

Overall average

\section{Moderate reforms}

$3 \quad 1994$

3 closed

$-42.30$

$-10.00$

$-47.29$

$-15.00$

$-42.61$

$-12.50$

Weak reforms

$\begin{array}{rcrr}2 & 1994 & -51.30 & -7.00 \\ 2 & 1994 & -54.30 & -25.00 \\ 2 & \text { closed } & -61.60 & 0.00 \\ 2 & \text { closed } & -51.01 & -25.00 \\ 2 & \text { closed } & -11.75 & -3.00 \\ & & -45.99 & -12.00\end{array}$

Weakest reforms

\begin{tabular}{lccc}
1 & 1994 & -35.93 & -22.00 \\
1 & closed & -54.32 & -22.00 \\
1 & closed & -85.35 & -35.00 \\
1 & closed & -70.37 & -25.00 \\
1 & closed & -38.29 & -20.00 \\
1 & closed & -51.36 & -23.00 \\
& & -55.94 & -24.50 \\
& & -38.63 & -7.58 \\
\hline
\end{tabular}

Source: European Bank for Reconstruction and Development (1994, 1995) with national sources for Bulgaria for 1994. 
to lead to economic convergence for the countries that join the system. In this paper we have provided strong evidence of convergence among open economies during the period $1970-89$, as well as evidence of accelerated growth in the countries that have recently undertaken market reforms.

Our analysis is necessarily impressionistic and imprecise at several crucial points. We have used trade policy as our measure of economic management, but we are strongly aware that trade policy represents just one element-albeit the most important-of an overall economic policy. Among developing countries, open trade has tended to be correlated with other features of a healthy economy, such as macroeconomic balance and reliance on the private sector as the main engine of growth. To some extent, opening the economy has helped to promote governmental responsibility in other areas. To that extent, trade policy should be viewed as the primary instrument of reform. But to some degree, our measure of trade policy serves as a proxy for an entire array of policy actions. Only further cross-country analysis, with a more detailed characterization of the entire policy regime, would allow us to distinguish the growth effects of the various components of economic policy.

It is tempting, at the end of the twentieth century, to believe that the birth of a global capitalist economy is inevitable. Some have proclaimed the "end of history" following the collapse of communism. Similarly, in 1910, Norman Angell declared that European wars had come to an end because war was simply too costly for any rational European government. But our historical review should give us profound pause for thought. Yes, the late twentieth century has certain key advantages over 1910 for the preservation of emerging market institutions. There is the spread of sovereignty, so that imperial adventures no longer seem to threaten the global peace. There is the spread of an international rule of law, largely through institutions such as the World Trade Organization and the International Monetary Fund. There is the spread of democracy, which covered some 108 countries in 1994, according to the estimates of Freedom House.

And yet there are also profound risks for the consolidation of market reforms in Russia, China, and Africa, as well as for the maintenance of international agreements among the leading countries. The consolidation of the emerging global arrangements will require the wisdom and 
leadership of the leading democracies ${ }^{81}$ The spread of capitalism in the twenty-five years since the start of the Brookings Panel is an historic event of great promise and significance, but whether we will be celebrating the consolidation of a democratic and market-based world system at its fiftieth anniversary will depend on our own foresight and good judgments in the coming years.

\section{A P P E N D I X}

\section{Data}

THE DATA SET in this paper begins with the sample of 135 countries included in version 5.5 of the data described in Summers and Heston (1991). For most of these countries, the growth variable (G7089) is calculated directly from the Summers and Heston data. For seven countries, Comoros, Ethiopia, Liberia, Tanzania, Nicaragua, Iraq, and Nepal, G7089 is calculated using 1970 and 1985 data on real GDP, rather than 1970 and 1989 data. Swaziland's $G 7089$ is calculated using real per capita GDP data from the World Bank for the years 1972 and 1989. With the single exception of Swaziland, G7089 is measured as average annual growth in per capita real GDP, and is expressed in a common set of prices (1985 international prices, in the Summers and Heston terminology).

Out of the Summers-Heston universe of 135 countries, there are 13 countries that do not have adequate growth data, either because they are not available at all, or because they are not available for a sufficiently long time span. At the time of writing, these countries are Afghanistan, Bahamas, Bahrain, Dominica, Grenada, Kuwait, Oman, St. Lucia, St. Vincent, Solomon Islands, Saudi Arabia, Sudan, and United Arab Emirates. After excluding these countries, the sample size falls to 122 .

81. See Sachs (1995a) for a discussion of some of the issues facing the advanced countries as the present global system is consolidated. 


\section{Variables Used to Classify Countries as Open or Closed}

The following are the variables used to classify countries as open or not open for the period 1970-89, and their sources:

$B M P 70$ and BMP80 Black market exchange rate premium, averaged over the 1970s and 1980s respectively. Source: Cowitt (1986) with updates from World Bank data (supplied by Ross Levine).

$B M P$ Dummy variable equal to 1 if either $B M P 70>0.2$, or $B M P 80>0.2$.

$E X M$

Dummy variable equal to 1 if a country had a score of 4 on the export marketing index in the World Bank study, Adjustment in Africa (Husain and Faruqee, 1994, p. 238). A score of 4 means that the country had extreme distortions resulting from its export marketing board. These boards are state-run monopsonies that typically purchase agricultural products at prices much below world prices, and then resell them at world prices. The study covered African countries only.

SOC Dummy variable equal to 1 if the country was classified as socialist in Kornai (1992, table 1.1).

$O W Q I$

Variable indicating coverage of quotas on imports of intermediates and capital goods. It is the ownimport weighted nontariff frequency on capital goods and intermediates. Includes licensing, prohibitions, and quotas. It is taken from Barro and Lee (1994) who, in turn, rely on UNCTAD data. The period covered is $1985-88$.

$O W Q I D$

Dummy variable equal to 1 if $O W Q I>0.4$.

OWTI

Variable indicating average tariffs on imports of intermediates and capital goods. It is the own-import weighted average tariff rate on capital goods 
and intermediates. It is taken from Barro and Lee (1994) who, in turn, rely on UNCTAD data. Period covered is $1985-88$.

OPEN Dummy variable equal to 1 for open economies. It is equal to 0 if a country scored a 1 on either the $B M P$ variable, the $S O C$ variable, the $E X M$ variable, or the $O W Q I D$ variable. If a country had some missing values and was not otherwise excluded, some effort was made to classify it as either a 0 or a 1 , as is discussed below. The tariff variable is not used in forming the $O P E N$ variable because it is redundant: all countries with $O W T I>0.4$ are already classified as closed on other grounds. If there were insufficient data to make a judgment, the country was assigned a "missing" value.

The reasoning behind the adjustments we made to the $O P E N$ variable is as follows. First, we know that we lack cross-country tariff and quota coverage data for the 1970 s, so we were especially concerned to find countries that had restrictive trade practices in the 1970s, but had reformed by the mid-1980s, and thus appeared open by the $O W Q I$ and $O W T I$ variable. We found one case, Morocco, and changed the $O P E N$ variable to 0 . Other adjustments were made for different reasons. South Africa followed an inward-looking development strategy throughout the 1970s and 1980s, and this was reinforced from outside as the rest of the world gradually tightened trade sanctions on South Africa in 1985. (Source: Lachman and Bercuson, 1992.) Hence, South Africa is rated as a closed economy. Lesotho and Swaziland were members of the Southern African Customs Union and thus were open in relation to the southern African region but closed in relation to the rest of the world. Since these economies are small relative to the South African market, we consider them inherently ambiguous cases and assign them "missing" values (Lesotho is a high-growth economy and Swaziland is a low-growth economy). Botswana is also a member of the customs union but is rated closed, based on a high black market exchange rate premium. Haiti was rated as closed, based on the extensive evidence for restrictive trade practices in Lundahl (1992). Luxembourg is a member of the EEC and 
is rated as open. New Zealand is rated as closed, based on evidence that quantitative trade restrictions covered more than 40 percent of imports in 1981 and 1983. (Source: Laird and Yeats, 1990, table 4.2.) Australia is rated as open, based on Caves and Krause (1984).

After these adjustments, there remained nine small countries for which we had insufficient data to make an informed assessment on the OPEN variable: Cape Verde, Comoros, Liberia, Iceland, Fiji, Malta, Panama, Seychelles, and Suriname. Therefore, whenever the analysis in the paper requires the $O P E N$ variable, the sample size is reduced to 111.

The following variables are used to define the $P O L$ dummy variable.

RIGHT

Dummy variable equal to 1 if a country scored a 6 or above (higher means more repressive) on either the political rights index or the civil liberties index in MacMillan, Rausser, and Johnson (1994, table 1, pp. 8-10).

$E D U$

Dummy variable equal to 1 in cases of extremely disruptive unrest. Intended to capture disruptive internal or external wars, coups, and revolutions. Constructed by the authors using several indicators. First, countries were assigned a 1 if they scored 0.6 or higher on the REVC70 or REVC80 index in Barro and Lee (1994). In addition, the following countries were assigned a 1 because of conflicts: Angola (sixteen-year civil war); Burundi (Hutu rebellion 1973-74, resulting in an estimated 160,000 deaths); Chad (repeated battles with Moslem rebels in the north); El Salvador (twelve-year civil war); Ethiopia (extended war with Somalia over control of the Ogaden region of Ethiopia); Guatemala (repeated conflicts between the military rulers and the guerrilla army of the poor); Iran and Iraq (war in the early 1980s); Israel; Mozambique (protracted civil war in the 1980s); Nicaragua (civil war); Panama (U.S. invasion in the late 1980s); Somalia (see Ethiopia); Sri Lanka (repeated violence with the Tamil and Sin- 
halese separatists); Uganda (invasion by Tanzania); Zimbabwe (revolt against government of Ian Smith in the late 1970s).

For the RIGHT variable, Hungary and Yugoslavia were assigned a 1 and Cote d'Ivoire and Hong Kong were assigned a 0 . The list of countries and their scores on these variables are listed in table A1.

The other variables used in this paper, along with sources, are as follows. The organization is by table.

\section{Variables Used in Tables}

Tables $1-5$

$E P A$

External payments arrears, as rated by the IMF's Annual Report on Exchange Restrictions.

$D C$

Country had a multilateral debt rescheduling, based on data in the World Debt Tables of the World Bank.

$H I$

Country had inflation above 100 percent, as recorded in the International Financial Statistics Yearbook, 1994, p. 64.

The sources for the dating are described in detail below for each country. Data for table 5 are from the European Bank for Reconstruction and Development's Transition Report (1994).

Table 8

POP60/LAND Population in 1960 (in thousands) divided by land area (in square meters).

POP60

Population in 1960.

$C W$

Dummy indicating British Commonwealth status, from Famighetti (1993).

$O L D S$

Dummy indicating old state, set to 1.0 for countries that achieved independence before World War II. 
Table A1. Variables Used to Construct the $P O L$ Variable $^{a}$

\begin{tabular}{|c|c|c|c|}
\hline Country & $\begin{array}{c}\text { Repression } \\
\text { of rights }\end{array}$ & Socialist $^{\mathrm{c}}$ & $\begin{array}{c}\text { Extremely } \\
\text { disruptive unrest }\end{array}$ \\
\hline Algeria & 1 & 0 & 0 \\
\hline Angola & 1 & 1 & 1 \\
\hline Argentina & 0 & 0 & 1 \\
\hline Bangladesh & 0 & 0 & 1 \\
\hline Benin & 1 & 1 & 0 \\
\hline Bolivia & 0 & 0 & 1 \\
\hline Burkina Faso & 0 & 0 & 1 \\
\hline Burundi & 1 & 0 & 1 \\
\hline Cameroon & 1 & 0 & 0 \\
\hline Cape Verde & 1 & 0 & 0 \\
\hline Central African Republic & 1 & 0 & 1 \\
\hline Chad & 1 & 0 & 1 \\
\hline China & 1 & 1 & 0 \\
\hline Congo & 1 & 1 & 0 \\
\hline Ecuador & 0 & 0 & 1 \\
\hline El Salvador & 0 & 0 & 1 \\
\hline Ethiopia & 1 & 1 & 1 \\
\hline Gabon & 1 & 0 & 0 \\
\hline Ghana & 0 & 0 & 1 \\
\hline Guatemala & 0 & 0 & 1 \\
\hline Guinea & 1 & 0 & 0 \\
\hline Guinea-Bissau & 1 & 0 & 1 \\
\hline Haiti & 1 & 0 & 0 \\
\hline Hungary & 1 & 1 & 0 \\
\hline Iran & 0 & 0 & 1 \\
\hline Iraq & 1 & 0 & 1 \\
\hline Israel & 0 & 0 & 1 \\
\hline Liberia & 0 & 0 & 1 \\
\hline Malawi & 1 & 0 & 0 \\
\hline Mali & 1 & 0 & 0 \\
\hline Mauritania & 1 & 0 & 0 \\
\hline Mozambique & 1 & 1 & 1 \\
\hline Myanmar & 1 & 0 & 0 \\
\hline Nicaragua & 0 & 1 & 1 \\
\hline Niger & 1 & 0 & 0 \\
\hline Panama & 0 & 0 & 1 \\
\hline Philippines & 0 & 0 & 1 \\
\hline Poland & 1 & 1 & 0 \\
\hline Rwanda & 1 & 0 & 0 \\
\hline Somalia & 1 & 1 & 1 \\
\hline Sri Lanka & 0 & 0 & 1 \\
\hline Syrian Arab Republic & 1 & 0 & 0 \\
\hline Tanzania & 1 & 0 & 0 \\
\hline Thailand & 0 & 0 & 1 \\
\hline Togo & 1 & 0 & 0 \\
\hline Uganda & 0 & 0 & 1 \\
\hline Yugoslavia & 1 & 1 & 0 \\
\hline Zaire & 1 & 0 & 0 \\
\hline Zimbabwe & 0 & 1 & 1 \\
\hline
\end{tabular}

Source: See appendix for complete definitions of variables and sources.
a. 1 indicates yes.
b. The dummy variable $R I G H T$.
c. The dummy variable $S O C$

d. The dummy variable $E D U$. 
$T L$

Table 11

GDP70

GDP89

G7089

SEC70

PRI70

$G V X D X E$

REVCOUP

$A S S A S S P$

PPI70DEV
The dependent variable is a dummy taking the value 1.0 if the country had opened by 1970 and stayed open.

Real GDP per capita in 1970 (1985 international prices) from Summers and Heston version 5.5.

Real GDP per capita in 1989 (1985 international prices) from Summers and Heston version 5.5.

Real per capita growth rate of GDP per year: $G 7089=[\ln (G D P 89)-\ln (G D P 70)] / 19$. Note that this variable is calculated differently for a few countries, as listed at the beginning of this appendix.

Secondary school enrollment rate. Source: Barro and Lee (1994).

Primary school enrollment rate. Source: Barro and Lee (1994).

Ratio of real government "consumption" spending net of spending on the military and education, to real GDP. Source: Barro and Lee (1994) who, in turn, used Summers and Heston version 5.5.

Number of revolutions and coups per year, averaged over the period 1970-85. Source Barro and Lee, 1994.

Number of assassinations per million population per year, 1970-85. Source: Barro and Lee (1994).

The deviation of the log of the price level of investment (PPP investment divided by exchange rate relative to the United States) from the crosscountry sample mean in 1970. Source: Authors' calculation based on the PISH5 price data in Barro and Lee (1994). 
INV7089

Ratio of real gross domestic investment (public and private) to real GDP, averaged over the period 1970-89. Source: Barro and Lee (1994) who, in turn, used Summers and Heston version 5.5.

Table 12

$D S Y R$

Average accumulation of secondary schooling over the period 1970-85. Specifically, $D S Y R=$ $[\ln (S Y R 85)-\ln (S Y R 70)] / 15$, where $S Y R x x$ is person years of secondary schooling divided by the total population over age fifteen.

$D P Y R$

Accumulation of primary schooling, calculated in the same manner as $D S Y R$.

Table 13

$X^{71}$

Primary export intensity in 1971. Ratio of primary exports to total exports in 1971, with both numerator and denominator expressed in nominal dollars. Primary exports are defined as agriculture, minerals, fuels, and metals. These correspond to SITC (revision 1) categories 0, 1, 2, 3, 4, and 68. Source: For all countries except Taiwan and South Africa, World Bank, World Tables, 1994. Data for Taiwan were obtained from the Taiwan Statistical Data Book (Republic of China, 1993). Data for South Africa include exports of raw diamonds and gold and were obtained from South Africa's Bulletin of Statistics, December 1972 and June 1992. Data for Singapore were estimated as 0.01 , based on GDP and labor force data indicating that Singapore produces no mining, no primary energy, and only a very small amount of agriculture, forestry, and fishing products. The data for Bangladesh are for 1972 rather than 1971. The data for Cameroon were set to 1.0; they exceeded 1.0 using the published data. 
Primary export intensity in 1989 , calculated in the same manner as $X^{71}$.

\section{Table 14}

The growth data for the recent reformers are real per capita growth from the World Tables of the World Bank. We did not use the data provided by Summers and Heston because we needed recent growth data.

\section{Background on Country Classifications}

Algeria

Angola

Argentina

Australia
Never open. The black market premium averaged 350 percent during 1985-90. Some trade liberalization began in the second stage of its reform program in 1991, but implementation was interrupted by political turmoil. Source: World Bank, Trends in Developing Economies, 1994 (TIDE), p. 6.

Never open. A protracted civil war has plagued the country since independence. Source: TIDE, p. 12.

Open since 1991. The average nominal tariff level for manufacturing was 141 percent in 1958 (Little, Scitovsky, and Scott, 1970, p. 163). The liberalization in 1976-80 did not sufficiently reduce effective rates of protection (estimated at 88 percent for all of manufacturing in 1980, from Cavallo and Cottani, 1991, table 3.19). The dating of the liberalization in 1991 is based on TIDE, p. 17.

Open since 1964. Australian tariffs were high by OECD standards, but the mean tariff did not exceed 40 percent. Source: Unpublished data from the World Bank. The date of liberalization is based on the evidence of the gradual relaxation of quantitative restrictions and import licensing in IMF, Annual Report on Exchange Restrictions, various issues. 
Austria

Bangladesh

Barbados

Belgium

Benin

Bolivia

Botswana
Open since 1960 , based on the date of full currency convertibility following membership in the European Free Trade Association. The IMF's Annual Report on Exchange Restrictions provides evidence of the liberal trading environment since 1960.

Never open. A phased import liberalization is in progress but implementation is very slow. Source: TIDE, p. 29.

Open since independence (November 30, 1966). Barbados qualifies on all the criteria for the period 1970-89.

Open since 1959. Member of the EEC. The average tariff in the Common Market was less than 40 percent in 1962. Source: Balassa (1965, table 1, p. 580). No major increase in protection 1962-93. Convertibility established in 1959.

Open since 1990. Not rated as open before 1990 because it has a score of 4 on its export marketing board (Husain and Faruqee, 1994, p. 238). By 1990 , Benin's score was 3, and the discussion in TIDE, p. 45, dates the start of the reform as 1989. Open 1956-79, closed 1979-84, open since 1985. The dating is based on black market premium data and information on trade policy in Sachs and Morales (1988).

Closed 1966-79, open since 1979. Membership in the Southern African Customs Union makes it hard to rate its trade policy as open or closed. It is open in relation to the southern African market, but since the countries in the customs union adopt South Africa's external tariffs, it is closed in relation to the rest of the world. In the end, we rated Botswana as closed in the 1970 s, based on its high black market premium data. The date of the opening in 1979 is based on the same data. 
Brazil

Burkina Faso

Burundi

Cameroon

Canada

Cape Verde

Central African

Republic
Open since 1991. Brazil is rated as closed before 1991 , based on the evidence in Coes (1991). Specifically, the average effective protection rates in 1967 and 1973 exceed 40 percent (see table 4.1). In addition, the index of trade liberalization (see figure 4.1) indicates that 1973 was the most liberal year during the period 1947-82, so we rate this period as insufficiently liberal by our standards. A high black market premium also disqualifies Brazil in the early 1960 s and the period $1975-89$. The 1991 dating is based on the reforms of the Collor administration.

Never open. Not rated as open before 1990 because it has a score of 4 on its export marketing board (Husain and Faruqee, 1994, p. 238). The state-controlled export monopsony is still in operation. There is no evidence in TIDE of a major recent reform effort.

Never open. Not rated as open before 1990 because it has a score of 4 on its export marketing board (Husain and Faruqee, 1994, p. 238). There is no evidence in $T I D E$ of a major recent reform effort.

Open since 1993. Not rated as open before 1990 because it has a score of 4 on its export marketing board (Husain and Faruqee, 1994, p. 238). The dating of the recent reform is based on TIDE, p. 78 .

Open since 1952, when it accepted article VIII status with the International Monetary Fund.

Insufficient evidence on trade policy.

Never open. Not rated as open before 1990 because it has a score of 4 on its export marketing board (Husain and Faruqee, 1994, p. 238). There is no evidence in $T I D E$ of a major recent reform effort. 
Chad

Chile

China

Colombia
Never open. Chad received a score of 4 on its export marketing board and thus is considered closed before 1990. In 1990 this rating was reduced to a 3 , so that Chad would potentially be open from this date. However, because there is considerable discussion of the lack of progress on trade reforms in TIDE, p. 93, we do not classify Chad as a reformer.

Open since 1976. Chile is classified as closed in the 1950s, based on the accounts of import prohibitions, licensing, and multiple exchange rates in various issues of the IMF's Annual Report on Exchange Restrictions covering the years 1950-61. For the 1960s, Chile is not rated as open because the mean black market premium was 54 percent. The 1976 dating for the liberalization is based on Dornbusch and Edwards in Bosworth, Dornbusch, and Laban (1994, pp. 84-85); as well as Papageorgiou, Michaely, and Choksi (1991, vol. 7, figure 2.3).

Never open. Rated as socialist in Kornai (1992). Trade policies have been progressively liberalized since 1978, but the trading system was still rife with quantitative restrictions at least through 1994. (See text for further discussion.)

Open since 1986. Colombia has had a complicated mixture of tariffs and quantitative restrictions since 1931. Its classification as closed is based on the fact that the index of trade liberalization in Garcia Garcia (1991) is fairly constant between 1950 and 1983, as well as evidence that average tariffs exceeded 40 percent in 1962, 1971, and 1973 (Díaz-Alejandro, 1976, p. 108). The liberalization episodes in 1954, 1966, and 1979 were too short to qualify as sustained liberalizations. The dating for the opening is based on evidence in Garay (1991) that average tariffs rates fell below 40 percent in 1986 and have stayed low up to the present. 
Congo

Costa Rica

Cote d'Ivoire

Cyprus
Never open. Not rated as open before 1990 because it has a score of 4 on its export marketing board (Husain and Faruqee, 1994, p. 238). There was an attempt at liberalization in 1987 , but it did not go far enough (TIDE, p. 117). The export marketing board was still rated as a 4 in 1990 .

Open 1952-61, closed 1962-85, open since 1986. In the 1950s Costa Rica had no exchange restrictions on foreign payments and no import licensing (IMF, Annual Report on Exchange Restrictions, various issues). Imports could be obtained freely at an exchange rate that was 17 percent more depreciated than the rate at which exports had to be surrendered to the central bank. In 1960 Costa Rica joined the Central American Common Market (CACM), so 1961 is chosen as the date of closure. The mean common external tariff in the CACM was 40 percent in 1966 (Carnoy, 1972, p. 14). Costa Rica had a mean black market premium in excess of 20 percent in the period 1960-64. The mean external tariff was 53 percent before 1986 (World Bank, 1992a, p. 86). The dating for the reform in the $1980 \mathrm{~s}$ is based on the decline in the black market premium to 1 percent (1985-89) and the 1986 tariff liberalization, which reduced the mean tariff to 26 percent (World Bank, 1992a, p. 86).

Never open. Received a score of 4 on its export marketing board, and thus is considered closed before 1990 (Husain and Faruqee, 1994, p. 238). In 1990 this rating was reduced to a 3. However, there are still extensive nontariff barriers, scheduled to be phased out by 1995. Source: TIDE, p. 125.

Open since independence. There are some infant industry tariffs but the mean has never exceeded 20 percent. Trade liberalization has been helped 
by the European Community's Mediterranean policy. Cyprus can export most products at low tariffs to the EEC and reciprocates with low tariffs on EEC products. There are no quantitative restrictions. Source: Wilson (1992).

Denmark

Dominican

Republic

Ecuador

Open since 1959. Although Denmark was not an original member of the EEC or the EFTA, its trade policy was harmonized with the rest of Europe. Dating is based on timing of convertibility throughout Europe.

Never open. The liberalization episode of 1981-86 did not go far enough. Another liberalization started in 1991, but has not progressed significantly. Source: TIDE, p. 135.

Open 1950-82, closed 1983-90, open since 1991. The dating of the initial liberal phase is based on the IMF's Annual Report on Exchange Restrictions from the early 1950s, which states that import licenses were, "in most cases," issued freely, and De Janvry, Sadoulet, and Fargeix (1991, p. 58), who report implied trade taxes for the period 1970-85. Extensive trade reform was started in 1990. By 1991 virtually all the nontariff restrictions had been eliminated. The maximum tariff was 35 percent in 1990. Source: Economist Intelligence Unit, Country Report 3, 1991; and TIDE, p. 140.

Egypt

Never open. The state-led development planning and import-substituting industrialization policies were established in the mid- to late 1950s, under Nasser. We lack hard data to gauge whether Egypt was open in the years immediately after World War II. Egypt has certainly not been open since 1960, the start of the first five-year period for which we have black market premium data. Between 1960 and 1980 the mean premium was 83 
percent. Furthermore, UNCTAD data in the mid1980s report an average effective import tariff of 49 percent (Barro and Lee, 1994). The assessment that Egypt's recent reforms are insufficient to qualify as open is based on TIDE, p. 145.

El Salvador

Open 1950-61, closed 1962-89, open since 1989. El Salvador assumed the obligations of article VIII in 1946. In the 1950s and early 1960s import licenses were not required, and there were few restrictions on payments or transfers abroad (IMF, Annual Report on Exchange Restrictions, various issues). In 1960, El Salvador joined the Central American Common Market (CACM), so 1961 is chosen as the date of closure. The mean common external tariff in the CACM was 40 percent in 1966 (Carnoy, 1972, p. 14). The mean external tariff was 53 percent 1966-86 (World Bank, 1992a, p. 86). The 1989 dating is based on TIDE, p. 151.

Ethiopia

Finland

Never open. Civil war and devastating famines started in the 1970s and continued through the mid-1980s (Famighetti, 1993, p. 762). A transitional government assumed power in May 1991, and a fragile truce prevailed in 1992. It is still too early to rate this as a reforming economy.

\section{Finland}

France

Open since 1960 , based on the date of full currency convertibility following membership in the European Free Trade Association. The IMF's Annual Report on Exchange Restrictions provides evidence of the liberal trading environment between 1960 and the present.

Open since 1959, based on date of full currency convertibility. Member of the EEC. The average tariff in the Common Market was less than 40 percent in 1962, Source: Balassa (1965, table 1, p. 580). No major increase in protection 1962-93.

Gabon

Never open. Not rated as open before 1990 because it has a score of 4 on its export marketing 
board (Husain and Faruqee, 1994, p. 238). The export marketing board is still rated as a 4 in 1990 . $T I D E$, p. 177 , only mentions a reform program in 1994.

Gambia

Germany

Ghana

Greece Open since 1959. Tariffs and quotas were already

Reform 1985. Not rated as open up to 1985 because of a score of 4 on its export marketing board (Husain and Faruqee, 1994 p. 238). The Gambia receives a 2 in 1990, and Husain and Farugee report virtually no administrative controls on foreign exchange allocation. The 1985 dating is based on the discussion of extensive trade liberalization efforts in TIDE, p. 181.

Open since 1959, based on date of full currency convertibility. Member of the EEC. The average tariff in the Common Market was less than 40 percent in 1962. Source: Balassa (1965, table 1, p. 580). No major increase in protection 1962-93.

Open since 1985. The black market premium fell from 1,098 percent (average 1981-86) to 3 percent (1990), falling below 20 percent in 1985. In 1990, 0 percent of foreign exchange allocation was controlled, and only two items were subject to nontariff barriers. The World Bank rates it as a 4 on the export marketing board in 1990 , but the discussion in TIDE, p. 191, has no mention of this as a constraint on openness. Hence we rate Ghana as open from 1985. low in mid-1950s (Eichengreen, 1994, table 1, p. 35, and Kottis, 1989, p. 335) and convertibility was established in May 1959 (IMF, Annual Report on Exchange Restrictions, 1960, p. 8).

Guatemala Open 1950-61, closed 1962-88, open since 1988. Guatemala assumed the obligations of article VIII in 1947. In the 1950s and early 1960s there was no import licensing nor significant restrictions on payments or transfers abroad (IMF, Annual Re- 
Guinea

Guinea-Bissau

Guyana port on Exchange Restrictions, various issues). In 1960, Guatemala joined the Central American Common Market (CACM), so 1961 is chosen as the date of closure. The mean common external tariff in the CACM was 40 percent in 1966 (Carnoy, 1972, p. 14). The mean external tariff was 53 percent 1966-86 (World Bank, 1992a, p. 86). The election of a civilian government in 1985 started a period of reform. The 1988 dating is based on TIDE, p. 196.

Open since 1986. Not open before 1986 due to a rating of 4 on its export marketing board (Husain and Faruqee, 1994, p. 238). In 1990 the World Bank reports a black market premium of 8 percent and gives Guinea a rating of 1 (most liberal) on its export marketing system. The 1986 dating is based on TIDE, p. 200, which reports a comprehensive dismantling of state-led development institutions, including external trade protection.

Open since 1987. Not open before 1987 due to a rating of 4 on its export marketing board (Husain and Faruqee, 1994, p. 238). In 1990 the World Bank reports a black market premium of -2 percent and gives Guinea a rating of 1 (most liberal) on its export marketing system. The 1987 dating is based on TIDE, p. 205.

Open since 1988. A high mean black market premium (298 percent) disqualifies Guyana between about 1975 and the late 1980s. Prior to 1988 there was an extensive list of import prohibitions and restrictions, which have since been greatly reduced (World Bank, 1993b, p. 32). In 1991 Guyana adopted the Caribbean Community (CARICOM) common external tariff schedule, with rates that average well below 40 percent. The 1988 dating is based on the assessment in TIDE, p. 210 , that this was the decisive year of reform. 
Haiti

Honduras

Hong Kong

Hungary

India
Never open. Extensive tariffs and quantitative restrictions protected domestic manufacturing from 1949 through 1986 (Lundhal, 1992, p. 407). There are special export zones in Haiti where firms are allowed to import intermediate products, assemble them, and then export, but these represent a small fraction of the economy. Since 1986 liberalization has been extremely slow. In 1990 the black market premium was still 40 percent (Lundahl, 1992, p. 418).

Open 1950-61, closed 1962-90, open since 1991. Honduras assumed the obligations of article VIII in 1950 . In the 1950 s and early 1960 s there were no significant restrictions on payments or transfers abroad (IMF, Annual Report on Exchange Restrictions, various issues). In 1960 Honduras joined the Central American Common Market (CACM), so 1961 is chosen as the date of closure. The mean common external tariff in the CACM was 40 percent in 1966 (Carnoy, 1972, p. 14). The mean external tariff was 53 percent 1966-86 (World Bank, 1992a, p. 86). An extensive trade reform between 1990 and 1992 included the elimination of import permits and administrative foreign exchange allocation. Import tariffs were reduced to a range of 5-20 percent (TIDE, p. 214).

Always open.

Open since 1990. Source: European Bank for Reconstruction and Development (1994).

Open since 1994. Rated as closed before 1991 due to very high tariffs and elaborate quantitative restrictions dating from the early 1950s (Bhagwati and Desai, 1970). The 1994 dating is based on the start of a trade liberalization program (TIDE, p. 223), and average tariff data in Krishna and Mitra (1994, p. 5). 
Indonesia

Iran

Iraq

Ireland

Israel
Open since 1970. Indonesia had a dual exchange rate system that ended April 17, 1970 (Pitt, 1991). The important trade liberalization measures were introduced between May 1966 and July 1967. Import licensing was eliminated in October 1966 (Pitt, 1991, p. 181). The median tariff rate had fallen below 40 percent by 1970 (Pitt, 1991, table 5.10 , p. 90, which relies on Rosendale, 1981, p. 276).

Never open. Iran maintained tight restrictions on imports through the annual publication of import lists by the Ministry of National Economy. The IMF's Annual Report on Exchange Restrictions for 1953 states that the ministry has prohibited a "large number of goods," although there is no quantification. The evidence of numerous administrative controls on foreign trade provided by Amuzegar (1977) leads us to classify Iran as closed. Black market premium data disqualify Iran after 1975.

Never open. Black market premium averaged 230 percent in the 1980s. Import quota system was in place in the early 1950s. All imports that competed with Iraqi new industries were on the prohibited list.

Open since 1966. Dating is based on membership in the Anglo-Irish Free Trade Area from 1966, and data provided by Ó Gráda and O'Rourke (1994, pp. 17, 29).

Open since 1985 . Israel initially pursued an import-substituting industrialization policy in the 1950s. Since then, there has been gradual liberalization, so the question is when Israel first qualifies as open. An import liberalization took place between 1962 and 1965, but Pack (1971, table 4.6) reports rates of nominal protection by sector that 
clearly average above 40 percent in 1965 . In addition, the mean black market premium was 25 percent in the 1970s, so Israel does not qualify as open during that decade. In 1975 Israel became an associate member of the European Community; at the same time, many countries followed the lead of the Arab countries in boycotting trade with Israel. The dating of 1985 is based on the signing of a free trade agreement with the United States and successful inflation stabilization. Sources: Razin and Sadka (1993) and Halevi and Baruh (1991).

Italy

Jamaica

Open since 1959, based on date of full currency convertibility. Member of the EEC. Average tariff less than 40 percent in 1962. Source: Balassa (1965, table 1, p. 580). No major increase in protection 1962-93.

Open from independence (1962) to 1973, closed 1973-89, open since 1989. The classification as open in the 1960s is based on various issues of the IMF's Annual Report on Exchange Restrictions, and data showing that the mean black market premium was only 6 percent. The IMF's 1967 report states that "most goods may be imported freely under an open general license" (p. 348). Jamaica is disqualified between the early 1970 s and the mid1980 s, based on a high mean black market premium. The 1973 and 1989 datings are based on $T I D E$, p. 239. Referring to the recent reforms, Williamson (1992) states: "Quantitative restrictions eliminated and tariffs lowered to 20 percent to 30 percent for most items" (p. 373).

Japan

Open since 1964, when Japan assumed the obligations of article VIII and established full currency covertibility (IMF, Annual Report on Exchange Restrictions, 1965). Average tariff was less than 
40 percent in 1962 . Source: Balassa (1965, table 1 , p. 580). No major increase in protection 1962-93.

Jordan

Kenya

Open since 1965 . Jordan appears to be a case of a moderately restrictive trade regime that nevertheless qualifies as open by our standards. The government has required import licenses since at least 1951 . In the 1950s Jordan allowed importing only by registered importers who were allocated foreign exchange based on the government's annual import plan. In the 1960s Jordan introduced a list of prohibited imports, but this included only a few products. By the mid-1960s the IMF reports state that import licenses were granted freely except for items on these lists (see, for example, IMF, Annual Report on Exchange Restrictions, 1967 , p. 361). The black market premium was low throughout the period 1960-90 (the mean is 4 percent), indicating that import restrictions did not lead to severe excess demand for foreign exchange. In 1987 the average import tariff was below our 40 percent threshold, at 33 percent (Husain and Faruqee, 1994, p. 37), and it has fallen since then.

Open 1963-67, followed by closing, and then reform in 1993. When it became independent in 1963, Kenya entered into a customs union that had internal free trade and a common external tariff with Tanzania and Uganda. The external tariff was 30 percent for most goods, but 0 percent for equipment, and 75 percent for luxuries such as cosmetics (Barve 1984, p. 27). The black market premium averaged less than 20 percent during the 1960 s. Hence Kenya qualifies as open by our criteria during this period. The liberalization ended with the Exchange Control Act of 1967 and was followed by a gradual increase in licensing and tariffs in the 1970s. Since the late 1980s there has 
been extensive trade liberalization, but the black market premium was higher than 20 percent in 1989 and 1990. Source: Husain and Faruqee (1994) and the Economist Intelligence Unit, various reports.

Korea

Open since 1968. The exchange rate was unified by the mid-1960s. The black market premium fell below 20 percent in the period 1965-69. A gradual reduction in import tariffs started in the mid1960s. Source: Nam (1989, pp. 165-66). By 1968, the average tariff was below 40 percent (Collins and Park, 1989, table 9.12).

Lesotho

Not rated. Ambiguous case due to membership in the Southern African Customs Union. (See discussion in appendix above.)

Liberia

Not rated. Insufficient data on trade policy.

Luxembourg

Open since 1959 , when convertibility was established. The average tariff in the Common Market was less than 40 percent in 1962. Source: Balassa (1965, table 1, p. 580). No major increase in protection 1962-93.

Madagascar

Never open. Not rated as open before 1990 because it has a score of 4 on its export marketing board (Husain and Faruqee, 1994, p. 238). The export marketing board was still rated as a 4 in 1990 . There is no mention of significant reform since (TIDE, p. 294).

Malawi

Never open. Closed since early 1970 s, based on a high black market premium as well as a rating of 4 on its export marketing board (Husain and Faruqee, 1994, p. 238). Not rated as a recent reformer, based on discussion in TIDE, p. 299.

Malaysia

Open since independence (1963). The black market premium has never exceeded 2 percent. In 1965 the IMF states that "most imports are per- 
Mali

Malta

Mauritania

Mauritius

Mexico

Morocco mitted freely under open general licenses" (IMF, Annual Report on Exchange Restrictions, 1965, p. 347). Malaysia qualifies on all of our trade indicators and there is no evidence of any major policy changes in the 1970 s (TIDE, p. 304).

Open since 1988. Pursued state-led development between independence in 1960, and 1988. State monopolization of exports (Husain and Faruqee, 1994, p. 238) and extensive import licensing (IMF, Annual Report on Exchange Restrictions, 1965, p. 353). Scores a 3 on the export marketing index in $1990 ; T I D E$, p. 314 , dates the reforms as starting in 1988.

Not rated, due to insufficient data on trade policies.

Open since 1992. Rated closed during 1970-90 because of a high black market premium, and a 4 on the export monopoly index. TIDE, p. 320, states that 1992 marks the decisive intensification of reforms.

Open since independence in 1968. Source: TIDE, p. 324.

Open since 1986. A combination of moderate tariffs and extensive import licensing since the early 1950s. In the 1960s, 80 percent of tariff lines were covered by licensing (Bueno, 1971, p. 181). A high black market premium also disqualifies Mexico in the early 1980s. The 1986 dating for the reform is based on TIDE, p. 328 .

Open from independence in 1956 , to 1964 , closed 1964-84, open since 1984. Imports could be made freely from French franc area countries up to 1964 (IMF, Annual Report on Exchange Restrictions, various issues). Introduction of a list of permitted imports, and prohibition of everything else, in 1964 (IMF, Annual Report on Exchange Restric- 
tions, 1965). In 1980 the mean unweighted tariff was 47 percent (IMF, Annual Report on Exchange Restrictions, 1995 , p. 33). The dating of the 1984 liberalization is based on Nsouli and others (1995, pp. 32-33). By the mid-1980s the quota coverage, mean tariff, and black market premiums were all below our thresholds for openness.

Mozambique

Never open. Not rated as open before 1990 because it has a score of 4 on its export marketing board (Husain and Faruqee, 1994, p. 238). TIDE, p. 351, does not present any evidence of a major recent reform effort.

Myanmar

Nepal

Netherlands

New Zealand

Nicaragua
Never open.

Open since 1991. Not rated open between 1960 and 1990 because of a high black market exchange rate premium. Not rated open in the 1950 s, based on evidence in Shreshtha (1981). The dating of the reform in 1991 is based on the discussion in TIDE, p. 356.

Open since 1959, based on date of full currency convertibility. Member of the EEC. The average tariff in the Common Market was less than 40 percent in 1962. Source: Balassa (1965, table 1, p. 580). No major increase in protection 1962-93.

Open since 1986. Quantitative trade restrictions covered more than 40 percent of imports in 1981 and 1983, and had fallen below 40 percent by 1986 (Laird and Yeats, 1990, table 4.2).

Open 1950-60, closed 1961-90, open since 1991. In the 1950s Nicaragua had import licensing and surcharges for acquiring foreign exchange for importing, but the licenses were freely granted and the average surcharge did not exceed 40 percent (IMF, Annual Report on Exchange Restrictions, various issues). The open period ends in the 1960s 
since the mean black market exchange rate premium exceeds 20 percent. In addition, Nicaragua adopted the high external tariffs of the Central American Common Market in the period 1966-86. The 1991 dating for the reform is based on TIDE, p. 361 .

Niger

Nigeria

Norway

Pakistan

Panama

Papua New Guinea
Never open. Not rated as open before 1990 because it has a score of 4 on its export marketing board (Husain and Faruqee, 1994, p. 238). TIDE, p. 365 , does not present any evidence of a sustained recent reform effort.

Never open. The black market premium averaged 68 percent for the period 1965-90. We lack good evidence from the early 1960s. The period 198692 may qualify as a liberalization (see $T I D E$, p. 365 , for example), but the average black market premium was 135 percent in $1985-89$, so we do not rate this as a liberalization.

Always open. Full currency convertibility in 1960 following membership in the European Free Trade Association. The IMF's Annual Report on Exchange Restrictions provides evidence of the liberal trading environment since 1960.

Never open. Insufficient data on the period 194755. In 1955 the average import tariff exceeded 40 percent (Islam, 1981, table 5.2, p. 60). Extensive import licensing through 1983. Pakistan's rating on Guisinger and Scully's (1991, p. 232) index of import liberalization would have to exceed 16 , indicating tariffs less than 50 percent, to qualify as open, and it never does during the 1960-83 period. The judgment that recent trade reforms have not gone far enough is based on TIDE, p. 391.

Not rated, due to insufficient data on trade policy.

Never open. The average black market premium was 27 percent in 1980-85. We lack data on trade 
policy to rate either the period between independence (1975) and 1980, or the late 1980s.

Paraguay

Peru

Open since 1989. The black market premium averaged 68 percent and 38 percent in the first and second halves of the 1980 s, respectively. The black market premium was eliminated when the exchange rate was unified in 1989. Trade liberalization also was implemented in 1989. By December 1989 the simple average tariff was 16.2 percent (World Bank, 1992b, p. 54).

Open 1948-67, followed by closing, and then open since 1991. Thorp and Bertram (1978) is the source for the dating of the temporary liberalization episode. It is supported by a low black market premium, which was 2 percent during 1960-64 and 8 percent during 1965-69. Peru is rated as closed during 1970-90 because of a high black market premium. The 1991 date for the recent reform is based on TIDE, p. 410.

Philippines

Open since 1988. The assessment that the Philippines was not sufficiently open in the 1950 s is based on data in Intal and Power (1990, table 2.4) that the average rate of protection exceeded 40 percent in the 1960s, and also on Papageorgiou, Michaely, and Choksi (1991, vol. 2, figure 2.12, p. 24) who rate the 1950s as less open than the 1960s. For later periods, we rely on our indicators, and on Shepherd and Alburo (1991) and TIDE, p. 414.

Poland

Open since 1990. Source: European Reconstruction and Development Bank (1994).

Portugal

Always open. The dictatorship in power 1928-74 did not introduce extremely restrictive tariffs (Avillez, Finan, and Josling, 1988, p. 19). Charter member of the European Free Trade Association (EFTA) in 1959. Portugal was granted a special 
timetable for removing tariffs, but average tariff levels were low and applied mainly to agricultural products. The postrevolution government in 1974 sought a delay on the tariff reductions but undertook no increase in protection rates (Avillez, Finan, and Josling, 1988). We have found no source that reports average tariff rates for Portugal, but based on our reading of Avillez, Finan, and Josling (1988) and our knowledge of the tariff rates of other EFTA countries, it is very unlikely that Portugal's average tariff exceeded 40 percent. Trade liberalization resumed in 1980 .

Rwanda Never open. Not rated as open before 1990 because it has a score of 4 on its export marketing board (Husain and Faruqee, 1994, p. 238).

Senegal

Sierra Leone

Never open. Not rated as open before 1990 because it has a score of 4 on its export marketing board (Husain and Faruqee, 1994, p. 238). TIDE, p. 437, does not present any evidence of a major recent reform effort.

Never open. Not rated as open before 1990 because it has a score of 4 on its export marketing board (Husain and Faruqee, 1994, p. 238). The state-controlled export monopsony is still in operation. The average black market premium was 408 percent in 1985-90. There is no evidence in TIDE of a major recent reform effort.

Singapore Open since independence in 1965.

Somalia

Never open. Average black market premium exceeded 20 percent in the 1970s and 1980s. Rated as socialist by Kornai (1992). In 1992 the United Nations declared Somalia a country without a government (Famighetti, 1993, p. 808).

South Africa Open since 1991. Source: Lachman and Bercuson (1992, pp. 32-37). South Africa has traditionally 
followed an import-substitution and inward-looking development strategy. This was reinforced by externally imposed trade and financial sanctions in 1985. The United States and several other countries began lifting trade sanctions in the summer of 1991. Thus although it is hard to put a precise date on qualification as open, 1991 seems a reasonable assumption.

Spain

Open since 1959. In July 1959 Spain unified its exchange rate, liberalized imports, and made its currency convertible with the currencies of other Organization for European Economic Community (OEEC) countries (IMF, Annual Report on Exchange Restrictions, 1960, p. 284). The sum of tariffs and indirect taxes on imports averaged 18.1 percent in 1961, and fell gradually for the next 27 years (Gamir, 1990).

Sri Lanka

Open 1950-56, closed 1956-77, open 1977-83, closed 1983-91, open since 1991. The dating is based on Cuthbertson and Athokorala (1991). The dating for 1983 is based on the annual black market premium data in Cowitt (1986).

Swaziland Not rated. Inherently ambiguous case due to membership in the Southern African Customs Union. (See discussion in appendix above.)

Sweden

Open since 1960 , based on the date of full currency convertibility following membership in the European Free Trade Association. No black market exchange rate premium; average tariff less than 40 percent in 1962. Source: Balassa (1965, table 1, p. 580). No major increase in protection 1962-93 (IMF, Annual Report on Exchange Restrictions, various issues).

Switzerland

Always open. Full currency convertibility. Membership in the European Free Trade Association 
since 1960 . No black market exchange rate premium, and low tariffs since at least 1950.

Syrian Arab Republic

Taiwan

Tanzania

Thailand

Togo

Trinidad and

Tobago
Open 1950-65, closed since 1965. The dating of the initial phase of liberalization is based on the IMF's Annual Report on Exchange Restrictions, 1950-66, which does not report any significant import barriers. This open era ended in 1965, when a state trading company, SIMEX, was granted a monopoly on the purchase of imports. In 1965 SIMEX purchases represented 55 percent of all imports (IMF, Annual Report on Exchange Restrictions, 1966, p. 521). Classified as closed during the 1980s due to a high quota coverage and a high black market premium. The country had multiple exchange rates for everything in 1993, and current account restrictions, according to the IMF's Annual Report on Exchange Restrictions, 1993. The average effective import tariff was 27 percent in the mid-1980s. In 1980s the quota coverage was above 40 percent and the black market premium was well above 20 percent. There is no evidence of recent reform.

Open since 1963, based on Lin (1993).

Never open. Not rated as open before 1990 because it has a score of 4 on its export marketing board (Husain and Faruqee, 1994, p. 238). Tanzania is not rated as a reformer since 1990 , due to the discussion in TIDE, p. 475.

Always open. Source: Phongpaichit (1992).

Never open. Not rated as open before 1990 because it has a score of 4 on its export marketing board (Husain and Faruqee, 1994, p. 238). Togo is not rated as a reformer since 1990 due to the discussion in TIDE, p. 486.

Never open. Based on our indicators and the discussion in TIDE, p. 490. 
Tunisia

Open since 1989. Rated not open in the 1960s because the black market premium exceeded 20 percent. The dating of reform is based on Nsouli and others (1993, pp. 26-29). Extensive import licensing was in place in 1985 , covering 82 percent of imports. A five-year trade reform program started in 1986 , precipitated by the decline in oil prices in January 1986. The first stage (1986-88) saw liberalization of intermediates and capital goods; the second stage (1988-91) saw further liberalization of consumer goods. By 1989 the coverage of nontariff barriers had fallen below 40 percent for the first time. The black market premium data show a small premium ( 7 percent) starting as early as 1975. The IMF's Annual Report on Exchange Restrictions records no current account restrictions in 1989.

Turkey

Open 1950-53, closed 1954-88, open since 1989. The dating of the first liberalization episode is based on Togan (1994, p. 20) and Krueger (1978). The economy was closed after a massive crop failure in 1954 (Togan, 1994). The black market premium exceeded 20 percent throughout the 1960s. Trade liberalization was started in the 1980 s, but not until 1989 did average nominal tariff rates fall below 40 percent (Togan, 1994, tables 2.11 and 2.12 , pp. 52-53).

Uganda

Open since 1988. Not rated as open before 1988 because it has a score of 4 on its export marketing board (Husain and Faruqee, 1994, p. 238). The 1988 dating is based on TIDE, p. 538.

United Kingdom

Always open. No black market exchange rate premium, and average tariff was less than 40 percent in 1962. Source: Balassa (1965, table 1, p. 580). No major increase in protection 1962-93. Convertibility established in 1959. 
United States

Uruguay

Venezuela

Yemen Arab

Republic

Yugoslavia

Zaire
Always open. No black market exchange rate premium, and average tariff was less than 40 percent in 1962. Source: Balassa (1965, table 1, p. 580). No major change in protection 1950-93.

Open since 1990. Uruguay is rated as closed in the 1950s, based on various issues of the IMF's $A n$ nual Report on Exchange Restrictions and the discussion in Favaro and Spiller (1991). High average tariff rates, given in Favaro and Spiller (1991, table 2.10), mean that Uruguay was also closed from 1961 through 1982. The 1990 dating is based on TIDE, p. 521 .

Open 1950-59, closed 1960-89, open 1989-93, closed since 1993. In the 1950s Venezuela was bound by a trade agreement with the United States that kept protection low (Allen, 1977, p. 92). The lack of exchange restrictions during this period is confirmed by the IMF's Annual Report on Exchange Restrictions. In 1959 a new government used the treaty's escape clause and sharply increased protection (Allen, 1977, p. 92). The dates for the second temporary liberalization are based on TIDE, p. 530.

Always open. North Yemen, which has been independent since 1918 as the Yemen Arab Republic, is rated as open due to its low black market premium, low quota coverage, and an average tariff of less than 40 percent. South Yemen (the People's Democratic Republic of Yemen) merged with North Yemen in 1990; we do not rate it separately, prior to that date.

Never open. Socialist, according to Kornai (1992).

Never open. Zaire has never pursued open economic policies, and there has been no recent reform under Mobutu. Source: TIDE, p. 548. 
Zambia

Zimbabwe
Open since 1993. Not rated as open before 1990 because it has a score of 4 on its export marketing board (Husain and Faruqee, 1994, p. 238). The 1993 date is based on TIDE, p. 538.

Never open. The Federation of Rhodesia (Zimbabwe) and Nyasaland, established in 1953, had very high rates of protection. This economic isolation was intensified with the imposition of United Nations sanctions in 1966. Source: Ndlovu (1994, pp. 10, 59). Rhodesia, and after its independence in 1980, Zimbabwe, had a black market premium that averaged above 90 percent in the 1970s and 1980s. It is also rated as closed because it is on Kornai's (1992) list of socialist economies. It is not rated as a recent reformer, due to the discussion in TIDE, p. 553. 


\section{Comments and Discussion}

Anders Åslund: Jeffrey Sachs and Andrew Warner have written a broad and most stimulating paper. They have included a large number of countries and formulated a clear hypothesis which can be statistically tested, thanks to a strict categorization.

Their main conclusion is that reform works and that there is no invincible poverty trap, which is easy to agree with. Even if countries experience falling GDP for years, they can catch up by adopting the right economic policies. A second conclusion is that openness to global integration is the crucial criterion of good economic policies, and the rest follows. That is less obvious. A third, less elaborated, theme is why some countries adopt the right policies at certain times, and others do not. Here the reasoning is neither complete nor stringent.

While the denial of an invincible poverty trap seems convincing, there are several factors to consider. The authors bring up a great many, but there are others; for instance, migration and various forms of international intervention. If we ignore racism and look upon all factors of production as transferable, it is indeed difficult to accept that a poverty trap is given once and for all.

However I feel uneasy with the word convergence, because it suggests that there is one ideal that everyone can learn; that the leaders can do no wrong or unlearn this ideal, and that their challengers can do no better. Coming from Sweden, I am firmly convinced that good economic policies and institutions can be unlearned and abolished. Argentina is a country with a longer record of economic unlearning. We are considering very long periods and this convergence may be temporary, lasting only a few decades.

Sachs and Warner have simply defined their criteria for an open economy, found the statistics for their categorization, and tested their hypotheses. In this fashion, they have largely avoided the question: 
Which are the necessary prerequisites for successful reform? They argue that relatively free foreign trade and a reasonably convertible currency are sufficient conditions for the success of economic reform; they assume, for instance, that macroeconomic stabilization follows.

The correlation between openness to foreign trade and the ability of poorer countries to catch up is convincing, but the causality needs to be proven further. What roles do other factors play? Usually, a government adopts a sensible policy covering many fields, and trade liberalization is only one aspect. For instance, liberalization and macroeconomic stabilization are usually introduced in parallel, in one package.

In recent years Sachs has presented a number of alternative lists of the four to six factors essential to the success of economic reform. ${ }^{1}$ All of them seem quite sensible. It would be useful to test these factors as far as possible to find the truly crucial preconditions of success. Common suggestions have been: openness to foreign trade, domestic liberalization, convertibility, macroeconomic stabilization, international financing, a pegged exchange rate, mass privatization, a social safety net, and certain political criteria (strong leader, insightful political elite, civil society, manageable interest groups, political pluralism, public education). Apart from international financing, all of these criteria are institutional, which makes testing more complicated.

The liberalization of foreign trade and the introduction of a convertible currency are hardly sufficient conditions for economic growth. A country with a very open economy can have bad incentives in the form of excessive taxes and public expenditures, and stay at a suboptimal equilibrium for decades. Sweden is an obvious example. In a recent paper Sachs has written about the entitlement trap in eastern Europe, particularly in Hungary. ${ }^{2}$

Similarly, the importance of a social safety net has been exaggerated in the discussion of former socialist countries. I am struck by its absence in discussions of East Asia. It is difficult to understand why a social safety net is enormously important in eastern Europe and of no consequence in East Asia. Clearly the social safety net has a bigger place in political rhetoric than in sound economic analysis. Even Russia had social expenditures of 21 percent of GDP in $1994 .{ }^{3}$ No country at this level

1. See, for example, Sachs $(1992,1995$ d, 1995e).

2. Sachs $(1995 b, 1995 c)$.

3. Shapiro (1994). 
of economic development has been successful with such large social expenditures.

An issue that is likely to prove important, and that applies to third world countries as well, is privatization. The degree of privatization will contribute to our understanding of the transition of the former communist countries in the longer run. Therefore we should include the relative size of the private sector as a plausible precondition for success.

Previously, Sachs made a strong case for international financing, but that is missing from this paper. ${ }^{4}$ It would have been interesting to have seen a discussion of the role of international financing in successful economic reform here. However, the case may be hard to prove because international financing has been connected with very different kinds of conditionality.

The Soviet Union gave a lot of foreign aid, but it was conditional on devastating economic policies. The Nordic countries have given huge amounts of aid to socialist countries in Africa, particularly to Tanzania, on the understanding that they build African socialism. The West gave export credits to benign communist states such as Yugoslavia under Josip Broz Tito, Poland under Edward Gierek, and Hungary under Janos Kadar, so that they could maintain liberal communist policies. None of this aid did much good.

Clearly, international financing is beneficial only if it is accompanied by the right conditionality, but views of what is right have changed very fast. As a result there is great skepticism of the benefits of foreign financing. A key question is: Under what conditions is international financing objectively beneficial? Which conditions are really necessary, and which are superfluous or even harmful? Until we can provide clear answers to these questions, it will be difficult to convince people of the need to provide international financing to developing countries.

Probably the most fun part of the paper is the discussion of why reforms happen, but it is not fully elaborated. It contains very interesting points, for example, that ideology and elites are more important than interest groups in countries with poor political structures. But the number of possible causes is large and more factors should be brought into the discussion. For instance, the paper discusses the significance of land, although natural resource endowment in general appears more relevant.

I know that Sachs and Warner are writing another paper on the theme

4. Sachs (1995d). 
that natural resources imply rents, and that if there are a lot of rents in a society, rent-seeking develops, which is the opposite of profit-seeking and the sound economic policies that lead to growth. This kind of reasoning should be included in the first part of this paper.

It is surprising that the authors do not find statistical evidence that small countries can liberalize their foreign trade regime more easily than large ones. There are strong reasons why small countries should tend to liberalize earlier than large ones. The politics of reform is much easier in a country with less political complexity, and the costs of the economic distortions caused by protectionism are much more forceful in a small economy than in a large economy, such as China. I wonder if this lack of evidence may reflect some flaw in methodology. If you distinguish between regions, it might turn out that the smallest countries in each region tend to liberalize most. Notably there are many small countries in Africa, which has not been very liberal overall, but few in the generally more liberal Asia.

A minor point concerns the comment that the Meiji restoration was the first shock therapy in history. While it certainly can qualify as shock therapy, it was not the first. The big liberalizations in Europe in the middle of the nineteenth century were outstanding examples, especially the massive deregulation in Britain in 1846. It is noteworthy that this was followed by three decades of laissez faire because the legal system and the public administration were too weak to be effective, and excessive reliance on them would have exacerbated corruption.

Finally, on the outlook for the future the paper compares our time with the end of the nineteenth century to argue that a global capitalist system is taking shape. Yet this builds upon two assumptions: first, that trade policy is the driving force, and second, that trade policy is set firmly on a liberal track. Considering how difficult it was to conclude the Uruguay Round and to convince the U.S. Congress to vote for the ratification of the GATT and the NAFTA, the commitment to trade liberalization does not appear all that strong.

If we focus on something other than trade liberalization, the parallel with the end of the nineteenth century does not hold. Another key feature of the period before 1914 was financial stability and currency stability, whereas our time is characterized by extreme financial instability. Failure to deal with currency instability typically leads to protectionism. So which comes first, financial stability or foreign trade regime? I fear 
that our understanding of the causality between these two factors is too limited to warrant the degree of optimism that Sachs and Warner express.

This worry is further aggravated by the state of international politics. As the authors rightly point out, the period before 1914 was characterized by British world dominance. The end of the cold war appears to have brought an end to U.S. world dominance. Today the United States neither perceives sufficient international threats nor has sufficient interest to spend the resources on foreign policy necessary to stay a world leader. Nobody else is prepared to take up world leadership. Therefore the current political situation is reminiscent of the situation immediately after World War I, at the time of the Versailles peace treaty.

So what are we to expect in this situation? We are likely to see international crises developing, perhaps in the currency sphere, and no one will be strong enough to deal with them. For global economic success, we need international institutions that can handle major international economic problems. However the institutional innovations since the end of the cold war have been miserable: the European Bank for Reconstruction and Development, the Maastricht treaty, and the Commonwealth of Independent States. The League of Nations and the International Labor Organization, which emanated from the Versailles peace process, appear masterpieces in comparison.

Stanley Fischer: Sachs and Warner have given us an interesting, challenging, and in places splendidly written, tripartite paper, ranging over the last two centuries and the entire globe, with views that run the gamut from Marx and Engels to Pollyanna, and ending with a degree of caution that, while appropriate, is not consistent with the rest of the paper.

I will discuss the paper in the order in which it is presented, starting with the global economy of a century ago, then turning to the reasons that the liberal-market-capitalist model lost favor in the 1930s and 1940s, then to the empirical results, and finally, to what we should make of it all.

\section{The Global Economy}

Many aspects of the global economy are indeed closer now to what they were a century ago than to what they were fifty years ago. At the 
close of the nineteenth century countries were linked through trade, as well as through massive capital flows corresponding to current account deficits and surpluses on a scale, relative to GDP, that would hardly be acceptable today. The international capital markets were highly integrated in at least two senses: first, that rates of return in the major markets of London, New York, and Paris moved together and, as a result of the invention of the telegraph, very rapidly so; and second, that, as Sachs and Warner tell us, the British colonies and dominions, much of Latin America, and Russia borrowed in those markets to finance development. Then, as now, there were occasional financial panics and debt difficulties in the developing countries, the Argentina-related Barings crisis of 1890 among them. I will come back to the question of the role played by the gold standard in promoting these capital flows.

Sachs and Warner point to the Universal Postal Union (UPU) and the International Telegraph Union as early exemplars of international institutions, but those are technical institutions, the running of which involves very little that is genuinely political. ${ }^{1}$ Rather, the international system was run mainly by Britain, in the framework of the gold standard, with the Bank of England acting as lender of last resort-albeit not systematically or with much thought to its international obligations.

We need to take a moment to reflect on the picture of the success of the international system painted in the famous quote from Keynes. His description of the London gentleman, probably yet abed, who commands the world's resources through his telephone, applied directly to very few people. The benefits of globalization in the British colonies probably accrued largely to the European settlers, not to the natives. No doubt there was a trickle down from the growing prosperity of the settlers to the natives who worked for them, but that was-except in the case of a few missionaries-largely the work of the invisible hand. The general lack of explicit concern for the colonized must have contributed to the economic philosophy of the early-postcolonial leaders, to which Sachs and Warner refer.

It is hard to judge from this distance to what extent global living standards were converging at the end of the nineteenth century. Labor migration to new countries must have helped bring about convergence

1. My LSE tutor, the late Leonard Schapiro, once asked me why no one studies the successful international organizations, like the UPU, rather than those that do not work. I did not take the hint, but perhaps someone else will. 
among people of European origin, but we do not have evidence of convergence among non-European countries or among people of nonEuropean origin. The evidence by Williamson quoted in the paper relates largely to European countries. Almost certainly, labor mobility played an important role in bringing about whatever degree of convergence was attained in that era.

\section{Policy and Ideological Changes}

Sachs and Warner are right to characterize Keynes's 1933 comments on the benefits of autarky as muddleheaded. But they very much underestimate the role of the Great Depression and of the apparent success of the Soviet model in the 1930s in bringing about the change in thinking that they deplore. Indeed, Keynes was speaking at a time when Britain was doing better than the United States, after it had moved away from its more liberal trade policies of the period up to 1930.

In the 1930s the United States economy went into deep depression from which it emerged very slowly; full employment returned only with a war-driven increase in aggregate demand. In the words of Don Patinkin, "the period was one of fear and darkness as the Western world struggled with the greatest depression that it had known."2 By contrast, the Soviet economy, according to the data and eyewitness accounts, was bounding ahead under the Stalinist planning regime that began in 1928. Further, wartime planning in the victorious countries succeeded not only in mobilizing resources for the war, but also in maintaining full employment-and in the United States and the United Kingdom, as well as in many other countries, increasing prosperity.

It is not hard to see why views on the role of the state changed between 1914 and 1945. It is more remarkable that the United States and Britain, in 1944 and 1945, managed to impose their vision of a liberal trading system on the architecture of the international system that emerged at Bretton Woods. A clear-headed look at the evidence of the last few decades at that point should have led most people to view the market model with suspicion, and a large role for the state with approbation-and it did.

2. Patinkin (1978, p. 3). 


\section{The Evidence}

After providing us with their Olympian view of world economic history over the last century, Sachs and Warner turn to the evidence of the last quarter century. One of their main conclusions is quite extraordinary: that countries with open economies will converge to the same level of income, although admittedly it will take a long time. ${ }^{3}$ This result provides so much comfort to the international agencies that in my official role, I should accept the conclusion and move on. But it is nonetheless necessary to check the details of the argument.

First, while it is impossible to categorize countries perfectly, the groupings used in this paper do raise difficulties. I feel about them much as I do about most newspapers, that they are very accurate on matters about which I know little. I know for sure that Zimbabwe was not a socialist country in 1970; I do not believe that Jordan has been consistently open since 1970; Israel's trade reforms began in 1963, certainly not in 1985 , and it did suffer from macroeconomic crises after opening; it is odd to have both India and Hong Kong classified as open in 1995, when their degrees of openness are so different; it is unclear why Lesotho and Swaziland are categorized as open and South Africa as closed, when all three belong to a customs union. Of course, any such summary scheme is bound to have difficulties.

Second, by starting in 1970 , the authors stack the deck against the import-substituting strategy. Whatever happened later, Latin American and African countries did quite well in the 1950s and 1960s, despite their perverse regimes. We should not be surprised that it took so long for them to open up.

The strength of the Sachs-Warner results is surprising, given that the question that is being looked at, that of the influence of openness on growth, has been extensively studied before. While the early result that openness contributes to growth finds increasing support from recent work, no one has found such extraordinarily categorical results. Perhaps they have to do with the noncontinuous nature of the openness variable here, whereas it is generally continuous in other papers. It is

3. Ben-David (1994) shows greater convergence among countries that trade more with each other, a result that points in the same direction as Sachs and Warner, but is more qualified. 
particularly surprising that this paper reaches stronger conclusions than the World Bank's famous 1987 World Development Report, which was so roundly criticized for overreaching.

One key question is whether to believe the argument that openness will lead to absolute rather than conditional convergence. I cannot see any basis for that conclusion. There are reasons to think that steadystate per capita income levels in different countries are bound to differ, as a result of differences in saving rates, different rates of investment in human capital, and so forth. After all, income levels differ among states in the United States, they will always differ among individuals, and they will likely always differ among countries. Perhaps we can define convergence differently, to say that countries have converged if all individuals with the same amount of human potential have the same earnings (or utility) in whatever country they live-and perhaps by the time such convergence becomes relevant we will be able to measure human potential. In the meantime, the claim of absolute convergence is hard to accept.

The result that the labor-to-land ratio is the variable that determines the timing of liberalization is surprising. The argument seems to assume that the country is a democracy. Possibly the labor-to-land ratio is serving as a proxy for the country's size.

Sachs and Warner make two other claims that need further examination. The first is that no country that liberalized trade failed to grow. It is not clear how to define the trade regime of the zone franc in Africa, but trade with France, at least, was open. Yet these countries failed to grow during much of the $1980 \mathrm{~s}$. The second claim is that no country that liberalized subsequently suffered from a macroeconomic crisis. The obvious counterexample here is Mexico; as noted above, Israel is another.

\section{Conclusions}

This paper does not address the implications of the major change in the international system since Bretton Woods-the opening of the capital account. Sachs and Warner's results show that countries that open to trade tend to converge. What about countries that open to capital movements? Logically, opening to capital movements should speed convergence. But, of course, globalization of capital flows also tends to punish bad policies and reward good policies more than before. With 
monetary instability likely to impede capital flows, the need for a credible monetary policy becomes greater: that may help explain why the gold standard was part of the institutional structure within which capital flowed internationally a century ago.

Appropriately, Sachs and Warner conclude on a sober note. Openness is not enough to produce growth; stable macroeconomic policies, structural policies, and institutions are needed too. There are huge problems of development in Africa, and also in some other countries. There is no assurance that this moment of ideological convergence will last in economics. The sobriety is justified, but so is much of their optimism.

\section{General Discussion}

Whether the correlation between openness and growth can be largely attributed to the beneficial effects of trade received a range of comments. T. N. Srinivasan noted that trade policy and growth are both endogenous variables, making it hard to establish causality. He criticized growth regressions in general because of such endogeneity and because of measurement errors. He referred to some unpublished papers of Marcel Dagenais, at the University of Montreal, which show serious biases in such regressions due to measurement errors. Andrew Warner replied that the timing of events supported the causal interpretation in the paper. Policy choices on openness after World War II were generally made early in the postwar period or at the start of independence, before the 1970-89 period used in calculating the growth rates. The discussion of the postwar period in the paper indicates that policy choices at this time were based largely on intellectual and political considerations. In addition, the evidence in the paper on openness and macroeconomic crises measures openness in the 1970s and crises in the 1980s.

Srinivasan also pointed out that the simplest version of neoclassical trade theory suggests that openness should have only a level effect, not a long-run growth effect. Making trade into an engine for growth required a resort to vague externalities. Greg Mankiw interjected that the level effect predicted by the neoclassical model still takes time to fully work itself out, and so appears to cause growth in time series. James Duesenberry suggested another scenario linking trade and growth. Combining restrictive trade practices with overvaluation leads to an exchange crisis in which scarce export revenue gets used up by the import- 
substituting industries, bottlenecking expansion in other industries. The macroeconomic crisis comes when the country attempts further expansion anyway. Rudiger Dornbusch accepted the view that openness, broadly defined, contributes to growth through the exchange of ideas, technology, and factors of production. But he argued that merchandise trade is only a marginally important part of the openness that provides these benefits.

Sachs agreed that many elements of reform packages are crucial. The developing countries' choice of a closed trade policy was only part of a way of life under state-led industrialization. Trade liberalization alone would not be sufficient and should be interpreted as a proxy for the more far-reaching programs of reform that generally come with it. However, he regarded trade reform as the single most powerful element of these programs, both because of its direct effects and because open trade forces adoption of other parts of the reform agenda. Trade exerts this influence by imposing more rigorous competition, altering the political economy, constraining the government's macroeconomic policies and manipulations in the economy, and subjecting institutions that want access to international markets to the scrutiny and conditionality of the international environment.

The categorization of countries as open or closed drew discussion. James Duesenberry criticized the yes or no nature of the openness variable. Using Sri Lanka's 1977 reforms as an example, he argued that there is important variation in the degree of openness among countries. Sri Lanka had policies for pushing exports, restricting imports, and dealing with exchange shortages. For coconuts alone they had an export tax, a maximum local price, a replanting subsidy, and a fertilizer subsidy. Sachs conceded that the criteria used in the paper are necessarily somewhat arbitrary and that it is difficult to pin down just when a country becomes open. But he argued that the errors about timing are unlikely to be large when working with five-year intervals. Warner mentioned that, in many instances, the black market premium was the decisive variable in categorizing economies as closed or open. The premium is intended as a measure that reflects an array of restrictive trade practices. But Srinivasan pointed out that the premium is endogenous and may simply pick up the thinness of the black market, and that it will be affected by interest rates and penalties for dealing in the black market. Dornbusch suggested that the premium is an especially dubious measure if openness is broadly conceived to apply to more than merchandise trade. 
Discussion turned to the political economy of trade policy and the importance of ideology in the choice of economic paths after the war. Dornbusch noted that anti-fascism was as strong a motivation for economic liberalism in postwar Europe as anti-communism. Srinivasan noted that Nehru was heavily influenced by the Soviet model, citing the 1938 document of the Indian Congress Party's National Planning Committee which envisioned a number of state interventions including stateled development of heavy industry and development by import substitution. He found this influence unsurprising, and felt that the real question is why governments did not change their policies when the failure of their initial postwar path became evident, which in India was the case by the mid-1960s. Why were Korea, Taiwan, and Singapore able to switch, while India was not?

Duesenberry suggested that two kinds of selection bias might be affecting the paper's results. First, since most countries turned to openness following periods of severe crisis, the new policy was bound to look good. Second, ignoring reforms that are not maintained until the end of the sample period means that trade reforms that are not working are omitted from the sample. He noted that quite a few countries have reneged on reform. Ghana, the Gambia, and Kenya have all, at some point, pulled an about-face. Warner replied that to lessen the effect of the first bias they compared growth after reform with growth in the distant past, rather than in the immediate past. And as to the second bias, they failed to find hard evidence of a country that really had liberalized (by their standards), and then did an about-face because of slow growth. 


\section{References}

Alesina, Alberto, and others. 1992. "Political Instability and Economic Growth." Working Paper 4173. Cambridge, Mass.: National Bureau of Economic Research (September).

Allen, Loring. 1977. Venezuelan Economic Development: A Politico-Economic Analysis. Greenwich, Conn.: JAI Press.

Amsden, Alice H. 1989. Asia's Next Giant: South Korea and Late Industrialization. New York: Oxford University Press.

Amuzegar, Jahangir. 1977. Iran: An Economic Profile. Washington: Middle East Institute.

Avillez, Francisco, Timothy J. Finan, and Timothy Josling. 1988. Trade, Exchange Rates, and Agricultural Pricing Policy in Portugal. Washington: World Bank.

Balassa, Bela. 1965. "Tariff Protection in Industrial Countries: An Evaluation." Journal of Political Economy 73(6): 573-94.

Balassa, Bela, and associates. 1971. The Structure of Protection in Developing Countries. Baltimore: Johns Hopkins University Press.

Banks, Arthur S., and others, editors. 1991. Political Handbook of the World, 1991. Binghamton, N.Y.: CSA Publications.

Barro, Robert J. 1991. "Economic Growth in a Cross Section of Countries." Quarterly Journal of Economics 106(2): 407-43.

Barro, Robert J., and Jong-Wha Lee. 1993. "International Comparisons of Educational Attainment." Journal of Monetary Economics 32(3): 363-94.

- 1994. "Data Set for a Panel of 138 Countries." Unpublished data set. Harvard University (January).

Barro, Robert J., N. Gregory Mankiw, and Xavier Sala-i-Martin. 1995. "Capital Mobility in Neoclassical Models of Growth." American Economic Review 85(1): 103-15.

Barro, Robert J., and Xavier Sala-i-Martin. 1991. "Convergence Across States and Regions." BPEA, 1:1991, 107-58. 1992a. "Convergence." Journal of Political Economy 100 (2): 223-51.

- 1992b. "Regional Growth and Migration: A Japan-United States Comparison." Journal of the Japanese and International Economy 6(4): 312-46.

1995. Economic Growth. New York: McGraw Hill.

Barve, Arvind G. 1984. The Foreign Trade of Kenya. Nairobi: Transafrica Press.

Bates, Robert H., editor. 1988. Toward a Political Economy of Development: A Rational Choice Perspective. Berkeley: University of California Press.

Bauer, P. T. 1954. West African Trade: A Study of Competition, Oligopoly and Monopoly in a Changing Economy. Cambridge: Cambridge University Press.

Baumol, William J., Richard R. Nelson, and Edward N. Wolff, editors. 1994. 
Convergence of Productivity: Cross-National Studies and Historical Evidence. New York: Oxford University Press.

Ben-David, Dan. 1993. "Equalizing Exchange: Trade Liberalization and Income Convergence." Quarterly Journal of Economics 108(3): 653-79.

- 1994. Trade Convergence Among Countries. Houston: University of Houston Press.

Bhagwati, Jagdish N., and Padma Desai. 1970. India: Planning for Industrialization: Industrialization and Trade Policies Since 1951. London: Oxford University Press.

Bhalla, Surgit S. 1994. "Freedom and Economic Growth: A Virtuous Cycle." Paper prepared for the Nobel Symposium on Democracies, Victory, and Crisis. Uppsala University, Sweden, August 27-30.

Bosworth, Barry P., Rudiger Dornbusch, and Raúl Labán, editors. 1994. The Chilean Economy: Policy Lessons and Challenges. Washington: Brookings.

Brau, Edward H., and others. 1983. "Recent Multilateral Debt Restructurings with Official and Bank Creditors." Occasional Paper 25. Washington: International Monetary Fund (December).

Bueno, Gerado. 1971. "The Structure of Protection in Mexico." In The Structure of Protection in Developing Countries, by Bela Balassa and associates. Baltimore: Johns Hopkins University Press.

Capie, Forrest H. 1983. "Tariff Protection and Economic Performance in the Nineteenth Century." Reprinted in Protectionism in the World Economy, edited by Forrest H. Capie. Brookfield, Vt.: Edward Elgar Publishing Co., 1992.

Carnoy, Martin. 1972. Industrialization in a Latin American Common Market. Washington: Brookings.

Cashin, Paul A. 1995. "Real GDP in the Seven Colonies of Australasia: 18611991." Review of Income and Wealth 41(1): 19-39.

Cavallo, Domingo F., and Joaquin Cottani. 1991. "Argentina." In Liberalizing Foreign Trade, vol. 1, The Experience of Argentina, Chile, and Uruguay, edited by Demetris Papageorgiou, Michael Michaely, and Armeane M. Choksi. Cambridge, Mass.: Blackwell.

Caves, Richard E., and Lawrence B. Krause, editors. 1984. The Australian Economy: A View from the North. Washington: Brookings.

Coes, Donald V. 1991. "Brazil." In Liberalizing Foreign Trade, vol. 4, The Experience of Brazil, Colombia, and Peru, edited by Demetris Papageorgiou, Michael Michaely, and Armeane M. Choksi. Cambridge, Mass.: Blackwell.

Colburn, Forrest D. 1994. The Vogue of Revolution in Poor Countries. Princeton, N.J.: Princeton University Press.

Collins, Susan M., and Won-Am Park. 1989. "External Debt and Macroeconomic Performance in South Korea." In Developing Country Debt and Economic Performance, vol. 3, edited by Jeffrey D. Sachs and Susan M. Collins. Chicago: University of Chicago Press.

Cowitt, Philip P., editor. 1986. 1985 World Currency Yearbook. Brooklyn, N.Y.: International Currency Analysis, Inc.

De Janvry, Alain, Elisabeth Sadoulet, and André Fargeix. 1991. Adjustment 
and Equity in Ecuador. Paris: Organisation for Economic Co-operation and Development.

De Long, J. Bradford. 1988. "Productivity Growth, Convergence, and Welfare: Comment." American Economic Review 78(5): 1138-54.

De Long, J. Bradford, and Lawrence H. Summers. 1991. "Equipment Investment and Economic Growth." Quarterly Journal of Economics 106(2): 445-502.

Díaz-Alejandro, Carlos F. 1976. Foreign Trade Regimes and Economic Development, vol. 9, Colombia. New York: National Bureau of Economic Research.

Dollar, David. 1992. "Outward-Oriented Developing Economies Really Do Grow More Rapidly: Evidence from 95 LDCs, 1976-1985." Economic Development and Cultural Change 40(3): 523-44.

Dowrick, Steve, and Duc-Tho Nguyen. 1989. "OECD Comparative Economic Growth 1950-1985: Catch-Up and Convergence." American Economic Review 79(5): 1010-30.

Durlauf, Steven N., and Paul A. Johnson. 1994. "Multiple Regimes and CrossCountry Growth Behavior." Unpublished paper. University of Wisconsin.

Economist Intelligence Unit. Various years. Country Profile, various countries. London: Economist Intelligence Unit.

- Various years. Country Report, various countries. London: Economist Intelligence Unit.

Edwards, Sebastian. 1989. Real Exchange Rates, Devaluation, and Adjustment: Exchange Rate Policy in Developing Countries. Cambridge, Mass.: MIT Press.

Eichengreen, Barry. 1994. "Institutions and Economic Growth: Europe After World War II." Discussion Paper 973. London: Centre for Economic Policy Research (June).

Eichengreen, Barry, and Marc Flandreau. 1994. "The Geography of the Gold Standard." Discussion Paper 1050. London: Centre for Economic Policy Research (October).

Eicher, Theo S. 1993. "Trade and Converging Growth Rates in a Model with Endogenous Human Capital and Technological Change: Dynamic Gains from Trade Reconsidered." Unpublished paper. Columbia University (December).

Estevadeordal, Antoni. 1994. "Measuring Trade Openness in the Early 20th Century." Paper prepared for the Thirteenth Latin American Meeting of the Econometric Society. Caracas, Venezuela, August 2-5.

European Bank for Reconstruction and Development. 1994. Transition Report: Economic Transition in Eastern Europe and the Former Soviet Union. London: European Bank for Reconstruction and Development.

1995. Transition Report Update. London: European Bank for Reconstruction and Development.

European Free Trade Association. 1987. The European Free Trade Association, third ed. Geneva: EFTA Secretariat. 
Famighetti, Robert, editor. 1993. The World Almanac and Book of Facts. Mahwah, N.J.: Funk and Wagnalls.

Favaro, Edgardo, and Pablo T. Spiller. 1991. "Uruguay." In Liberalizing Foreign Trade, vol. 1, The Experience of Argentina, Chile, and Uruguay, edited by Demetris Papageorgiou, Michael Michaely, and Armeane M. Choksi. Cambridge, Mass.: Blackwell.

Frankel, Jeffrey A., and David Romer. 1995. "Trade and Growth." Unpublished paper. University of California, Berkeley (January).

Friedman, Milton. 1953. Essays in Positive Economics. Chicago: University of Chicago Press.

Galy, Michel, Gonzalo Pastor, and Thierry Pujol. 1993. Spain: Converging with the European Community. Occasional Paper 101. Washington: International Monetary Fund (February).

Gamir, Luis, and others. 1986. Política Económica de España. Madrid: Alianza.

Garay, Luis Jorge. 1991. Apertura y Protección: Evaluación de la Política de Importaciones. Bogota: Tercer Mundo Editores.

Garay, Luis Gorge, and Antoni Estevadeordal. 1995. "Proyecto Sobre Ampliación de Mercados, Competencia y Protección en el Hemisferio Americano." Unpublished paper. Interamerican Development Bank (April).

Garcia Garcia, Jorge. 1991. "Colombia.” In Liberalizing Foreign Trade, vol. 4, The Experience of Brazil, Colombia, and Peru, edited by Demetris Papageorgiou, Michael Michaely, and Armeane M. Choksi. Cambridge, Mass.: Blackwell.

Gerschenkron, Alexander, and Nancy Nimitz. 1952. A Dollar Index of Soviet Petroleum Output, 1927-28 to 1937. Project Rand research memorandum RM-804. Santa Monica, Calif.: Rand Corporation.

Graham, Andrew, and Anthony Seldon, editors. 1990. Government and Economies in the Postwar World: Economic Policies and Comparative Performance, 1945-85. New York: Routledge.

Grossman, Gene M., and Elhanan Helpman. 1991. Innovation and Growth in the Global Economy. Cambridge, Mass.: MIT Press.

Guisinger, Stephen, and Gerald Scully. 1991. "Pakistan." In Liberalizing Foreign Trade, vol. 5, The Experience of Indonesia, Pakistan, and Sri Lanka, edited by Demetris Papageorgiou, Michael Michaely, and Armeane M. Choksi. Cambridge, Mass.: Blackwell.

Haberler, Gottfried. 1988. International Trade and Economic Development. San Francisco: International Center for Economic Growth.

Halevi, Nadav, and Joseph Baruh. 1991. "Israel." In Liberalizing Foreign Trade, vol. 3, The Experience of Israel and Yugoslavia, edited by Demetris Papageorgiou, Michael Michaely, and Armeane M. Choksi. Cambridge, Mass.: Blackwell.

Hamilton, Alexander. 1790. "Report on the Subject of Manufactures." In State Papers and Speeches on the Tariff, edited by F.W. Taussig. New York: Augustus M. Kelley, 1892. 
Harberger, Arnold C., editor. 1984. World Economic Growth. San Francisco: Institute for Contemporary Studies.

Headrick, Daniel R. 1981. The Tools of Empire: Technology and European Imperialism in the Nineteenth Century. New York: Oxford University Press.

Heckscher, Eli F. 1955. Mercantilism, second ed., translated by Mendel Shapiro and edited by E. F. Söderlund. New York: Macmillan.

Helliwell, John F. 1992. "International Growth Linkages: Evidence from Asia and the OECD." Working Paper 4245. Cambridge, Mass.: National Bureau of Economic Research (December).

Hobson, J. A. 1902. The Evolution of Modern Capitalism: A Study of Machine Production. London: W. Scott Publishers.

Husain, Ishrat, and Rashid Faruqee, editors. 1994. Adjustment in Africa: Lessons from Country Case Studies. Washington: World Bank.

Intal, Ponciano S., Jr., and John H. Power. 1990. Trade, Exchange Rate, and Agricultural Pricing Policies in the Philippines. Washington: World Bank.

International Monetary Fund (IMF). Various years. Annual Report on Exchange Restrictions. Washington: International Monetary Fund.

- Various years. Exchange Arrangements and Exchange Restrictions. Washington: International Monetary Fund.

Islam, Nurul. 1981. Foreign Trade and Economic Controls in Development: The Case of United Pakistan. New Haven, Conn.: Yale University Press.

Ito, Takatoshi, and Anne O. Krueger, editors. 1995. Growth Theories in Light of the East Asian Experience. Chicago: University of Chicago Press.

Keefer, Philip, and Stephen Knack. 1993. "Why Don't Poor Countries Catch Up? A Cross-National Test of an Institutional Explanation." Working Paper 60. College Park, Md.: Center for Institutional Reform and the Informal Sector (June).

Keynes, John Maynard. 1919. The Economic Consequences of the Peace. Reprinted as The Collected Writings of John Maynard Keynes, vol. 2. London: Macmillan, 1971.

- 1933. "National Self-Sufficiency." In The Collected Writings of John Maynard Keynes, vol. 21, Activities 1931-1939: World Crises and Policies in Britain and America, 233-46. London: Macmillan, 1982.

Kindleberger, Charles P. 1973. The World in Depression, 1929-1939. Berkeley: University of California Press.

King, Robert G., and Ross Levine. 1993. "Finance and Growth: Schumpeter Might Be Right." Quarterly Journal of Economics 108(3): 717-37.

Knack, Steve. 1994. "Institutions and the Convergence Hypothesis: The CrossNational Evidence." Working Paper 59. College Park, Md.: Center for Institutional Reform and the Informal Sector (May).

Kormendi, Roger C., and Philip G. Meguire. 1985. "Macroeconomic Determinants of Growth: Cross-Country Evidence." Journal of Monetary Economics 16(2): 141-63.

Kornai, Janos. 1992. The Socialist System: The Political Economy of Communism. Princeton, N.J.: Princeton University Press. 
Kottis, George C. 1989. Liberalizing Foreign Trade: The Experience of Greece. Washington: World Bank.

Krishna, Pravin, and Devashish Mitra. 1994. "Trade Liberalization, Market Discipline and Productivity Growth: New Evidence from India." Unpublished paper. Columbia University (December).

Krueger, Anne O. 1978. Liberalization Attempts and Consequences. Cambridge, Mass.: Ballinger.

- 1993. Economic Policies at Cross-Purposes: The United States and Developing Countries. Washington: Brookings.

Krugman, Paul. 1987. "The Narrow Moving Band, the Dutch Disease, and the Competitive Consequences of Mrs. Thatcher." Journal of Development Economics 27(1-2): 41-55.

Lachman, Desmond, and Kenneth Bercuson, editors. 1992. "Economic Policies for a New South Africa." Occasional Paper 91. Washington: International Monetary Fund (January).

Laird, Sam, and Alexander Yeats. 1990. Quantitative Methods for Trade-Barrier Analysis. New York: New York University Press.

Laothamatas, Anek. 1992. "The Politics of Structural Adjustment in Thailand: A Political Explanation of Economic Success." In The Dynamics of Economic Policy Reform in South-East Asia and the South-West Pacific, edited by Andrew J. MacIntyre and Kanishka Jayasuriya. New York: Oxford University Press.

Lardy, Nicholas R. 1994. China in the World Economy. Washington: Institute for International Economics.

Leamer, Edward E. 1988. "Measures of Openness." In Trade Policy Issues and Empirical Analysis, edited by Robert E. Baldwin. Chicago: University of Chicago Press.

$\rightarrow$ Lee, Jong-Wha. 1993. "International Trade, Distortions, and Long-Run Economic Growth." International Monetary Fund Staff Papers 40(2): 299-328.

Lenin, Vladimir I. 1926. Imperialism. The State and Revolution. New York: Vanguard.

Lerner, Abba P. 1936. "The Symmetry Between Import and Export Taxes." Economica 3 (August): 306-13.

Levine, Ross, and David Renelt. 1992. "A Sensitivity Analysis of Cross-Country Growth Regressions." American Economic Review 82(4): 942-63.

Lin, Ching-Yuan. 1973. Industrialization in Taiwan, 1946-72: Trade and Import-Substitution Policies for Developing Countries. New York: Praeger.

Lipton, Michael. 1976. Why Poor People Stay Poor. Cambridge, Mass.: Harvard University Press.

Lipumba, Nguyuru H. I. 1994. "Africa Beyond Adjustment.” Policy Essay 15. Washington: Overseas Development Council.

List, Friedrich. 1837. The Natural System of Political Economy. Reprint. Translated and edited by W. O. Henderson. London: Frank Cass and Company, 1983. 
Little, Ian, Tibor Scitovsky, and Maurice Scott. 1970. Industry and Trade in Some Developing Countries: A Comparative Study. London: Oxford University Press.

Lucas, Robert E., Jr. 1988. "On the Mechanics of Economic Development." Journal of Monetary Economics 22(1): 3-42.

Lundahl, Mats. 1992. Politics or Markets? Essays on Haitian Underdevelopment. London: Routledge.

Maddison, Angus. 1991. Dynamic Forces in Capitalist Development: A LongRun Comparative View. Oxford: Oxford University Press.

Mankiw, N. Gregory, David Romer, and David N. Weil. 1992. "A Contribution to the Empirics of Economic Growth." Quarterly Journal of Economics 107(2): 407-37.

Marx, Karl, and Friedrich Engels. 1848. "The Communist Manifesto." In Karl Marx: Selected Writings, edited by David McLellan. Oxford: Oxford University Press, 1977.

McEvedy, Colin, and Richard Jones. 1979. Atlas of World Population History. Great Britain: Penguin Books.

McMillan, John C., Gordon C. Rausser, and Stanley R. Johnson. 1994. "Economic Growth, Political and Civil Liberties." Occasional Paper 53. San Francisco: International Center for Economic Growth.

Nam, Koon Woo. 1989. South Korean Politics: The Search for Political Consensus and Stability. Lanham, Md.: University Press of America.

Naya, Seiji, and others, editors. 1989. Lessons in Development: A Comparative Study of Asia and Latin America. San Francisco: Institute for Contemporary Studies.

Ndlovu, Lindani B. 1994. The System of Protection and Industrial Development in Zimbabwe. Aldershot, England: Avebury.

Nsouli, Saleh M., and others. 1993. "The Path to Convertibility and Growth: The Tunisian Experience." Occasional Paper 109. Washington: International Monetary Fund (December).

- 1995. "Resilience and Growth Through Sustained Adjustment: The Moroccan Experience." Occasional Paper 117. Washington: International Monetary Fund (January).

Ó Gráda, Cormac, and Kevin O’Rourke. 1994. "Irish Economic Growth.” Discussion Paper 975. London: Centre for Economic Policy Research (June).

O'Rourke, Kevin, and Jeffrey G. Williamson. 1994. "Late Nineteenth Century Anglo-American Factor-Price Convergence: Were Heckscher and Ohlin Right?" Journal of Economic History 54(4): 892-916.

Owen, Thomas C. 1994. "Autocracy and the Rule of Law in Russian Economic History." Paper prepared for John M. Olin Lecture Series. Harvard University, Russian Research Center (October).

Pack, Howard. 1971. Structural Change and Economic Policy in Israel. New Haven, Conn.: Yale University Press.

Papageorgiou, Demetris, Michael Michaely, and Armeane M. Choksi, editors. 1991. Liberalizing Foreign Trade, 7 vols. Cambridge, Mass.: Blackwell.

Patinkin, Don. 1978. "The Process of Writing the General Theory.” In Keynes, 
Cambridge, and the General Theory, edited by Don Patinkin and J. Clark Leith. Toronto: University of Toronto Press.

Phongpaichit, Pasuk. 1992. "Technocrats, Businessmen, and Generals: Democracy and Economic Policy-Making in Thailand." In The Dynamics of Economic Policy Reform in South-East Asia and the South-West Pacific, edited by Andrew J. MacIntyre and Kanishka Jayasuriya. New York: Oxford University Press.

Pitt, Mark M. 1991. “Indonesia.” In Liberalizing Foreign Trade, vol. 5, The Experience of Indonesia, Pakistan, and Sri Lanka, edited by Demetris Papageorgiou, Michael Michaely, and Armeane M. Choksi. Cambridge, Mass.: Blackwell.

Pritchett, Lant. 1993. "Measuring Outward Orientation in Developing Countries: Can It Be Done?” Working Paper WPS 566. Washington: World Bank (October).

Razin, Assaf, and Efraim Sadka. 1993. The Economy of Modern Israel: Malaise and Promise. Chicago: University of Chicago Press.

Republic of China. 1993. Taiwan Statistical Data Book. Taipei: Council for Economic Planning and Development.

Reynolds, Lloyd G. 1985. Economic Growth in the Third World, 1850-1980. New Haven, Conn.: Yale University Press.

Rodriguez, Carlos Alfredo. 1974. "The Non-Equivalence of Tariffs and Quotas under Retaliation." Journal of International Economics 4(3): 295-98.

Rogowski, Ronald. 1989. Commerce and Coalitions: How Trade Affects Domestic Political Alignments. Princeton, N.J.: Princeton University Press.

Romer, Paul M. 1986. "Increasing Returns and Long-Run Growth." Journal of Political Economy 94(5): 1002-37.

- 1990. "Endogenous Technological Change." Journal of Political Economy 98(5): S71-S102.

Rosendale, Phyllis. 1981. "The Balance of Payments." In The Indonesian Economy During the Soeharto Era, edited by Anne Booth and Peter McCawley. Kuala Lumpur: Oxford University Press.

Rosenstein-Rodan, P. N. 1943. "Problems of Industrialisation of Eastern and South-Eastern Europe." Economic Journal 53(210): 202-11.

Sachs, Jeffrey D. 1985. "External Debt and Macroeconomic Performance in Latin America and East Asia." BPEA, 2: 1985, 523-64.

- editor. 1990. Developing Country Debt and Economic Performance, vol. 2, Country Studies: Argentina, Bolivia, Brazil, Mexico. Chicago: University of Chicago Press.

- 1992. "The Grand Bargain." In The Post-Soviet Economy: Soviet and Western Perspectives, edited by Anders Åslund. London: Pinter.

- 1994. "Notes on the Life Cycle of State-Led Industrialization." Paper prepared for the Ninth Annual Japan-U.S. Technical Symposium (March).

_. 1995a. "Consolidating Capitalism." Foreign Policy 98(Spring): 50-64.

1995b. "Postcommunist Parties and the Politics of Entitlements." Transition 6(3): 1-4.

-1995c. "Reforms in Eastern Europe and the Former Soviet Union in 
Light of the East Asian Experiences." Paper prepared for NBER-TCERCEPR Trilateral Conference on Transition from Socialist Economies, Tokyo, January 6-7.

- 1995d. "Russia's Struggle with Stabilization: Conceptual Issues and Evidence." In Proceedings of the World Bank Annual Conference on Development Economics 1994, edited by Michael Bruno and Boris Pleskovic. Washington: World Bank.

1995e. "Why Russia Has Failed to Stabilize." In Russian Economic Reform at Risk, edited by Anders Åslund. London: Pinter.

Sachs, Jeffrey D., and Susan M. Collins, editors. 1989. Developing Country Debt and Economic Performance, vol. 3, Country Studies: Indonesia, Korea, Philippines, Turkey. Chicago: University of Chicago Press.

Sachs, Jeffrey D., and Juan Antonio Morales. 1988. Bolivia 1952-1986. San Francisco: International Center for Economic Growth.

Sachs, Jeffrey D., Aaron Tornell, and Andrés Velasco. 1995. "The Collapse of the Mexican Peso: What Have We Learned?" Working Paper 5142. Cambridge, Mass.: National Bureau of Economic Research.

Sachs, Jeffrey D., and Andrew M. Warner. 1995. "Natural Resources and Economic Growth." Unpublished paper. Harvard University (January).

Sachs, Jeffrey D., and Wing Thye Woo. 1994. "Structural Factors in the Economic Reforms of China, Eastern Europe, and the Former Soviet Union." Economic Policy (April): 102-45.

Shapiro, Judith. 1994. "How Small Is Russian Social Expenditure?" Socio-economic Survey 2(1): 3-6.

Shepherd, Geoffrey, and Florian Alburo. 1991. "The Philippines." In Liberalizing Foreign Trade, vol. 2, The Experience of Korea, the Philippines, and Singapore, edited by Demetris Papageorgiou, Michael Michaely, and Armeane Choksi. Cambridge, Mass.: Blackwell.

Shreshtha, B. P. 1981. An Introduction to Nepalese Economy, fourth ed. Kathmandu: Ratna Pustak Bhandar.

Skidmore, Thomas E., and Peter H. Smith. 1984. Modern Latin America. New York: Oxford University Press.

South Africa. Various Years. Bulletin of Statistics. Pretoria: Department of Statistics.

Summers, Robert, and Alan Heston. "The Penn World Table (Mark 5): An Expanded Set of International Comparisons, 1950-1988." Quarterly Journal of Economics 106(2): 327-68.

Svensson, Jakob. 1994. "Investment, Property Rights, and Political Instability: Theory and Evidence." Seminar Paper 574. Stockholm: University of Stockholm, Institute for International Economic Studies (July).

Thorp, Rosemary, editor. 1984. Latin America in the 1930s: The Role of the Periphery in World Crisis. New York: St. Martin's.

Thorp, Rosemary, and Geoffrey Bertram. 1978. Peru 1890-1977: Growth and Policy in an Open Economy. New York: Columbia University Press.

Togan, Sübidey. 1994. Foreign Trade Regime and Trade Liberalization in Turkey During the 1980s. Aldershot, England: Avebury. 
Tomlinson, B. R. 1992. "Historical Roots of Economic Policy." In Foundations of India's Political Economy: Towards an Agenda for the 1990s, edited by Subroto Roy and William E. James, 274-308. Newbury, England: Sage Publications.

Wade, Robert. 1990. Governing the Market: Economic Theory and the Role of Government in East Asian Industrialization. Princeton, N.J.: Princeton University Press.

Warner, Andrew. 1994. "A Traded/Non-Traded Goods Approach to Exchange Rate Misalignment." Unpublished paper. Harvard University, Harvard Institute for International Development (July).

Waterbury, John. 1993. Exposed to Innumerable Delusions: Public Enterprise and State Power in Egypt, India, Mexico, and Turkey. New York: Cambridge University Press.

Wei, Shang-Jin. 1995. "The Open Door Policy and China's Rapid Growth: Evidence from City-Level Data." In Growth Theories in Light of the East Asian Experience, edited by Takatoshi Ito and Anne O. Krueger. Chicago: University of Chicago Press.

Williams, John H. 1949. Post-War Monetary Plans, and Other Essays. Oxford: Basil Blackwell.

Williamson, Jeffrey G. 1992. "The Evolution of Global Labor Markets in the First and Second World Since 1830: Background Evidence and Hypotheses." Working Paper on Historical Factors and Long Run Growth 36. Cambridge, Mass.: National Bureau of Economic Research (February).

1993. "Economic Convergence: Placing Post-Famine Ireland in Comparative Perspective." Discussion Paper 1654. Cambridge, Mass.: Harvard Institute of Economic Research (September).

Williamson, John, editor. 1990. Latin American Adjustment: How Much Has Happened? Washington: Institute for International Economics.

- editor. 1994. The Political Economy of Policy Reform. Washington: Institute for International Economics.

Wilson, Rodney. 1992. Cyprus and the International Economy. New York: St. Martin's.

Wolf, Holger. 1994. "Growth Convergence Reconsidered." Weltwirtschaftliches Archiv 30(4): 747-59.

World Bank. 1991. Nepal: Poverty and Incomes. Washington: World Bank. 1992a. Costa Rica: Strengthening Links to the World Economy. Washington: World Bank.

- 1992b. Paraguay: Country Economic Memorandum. Washington: World Bank.

- 1993a. The East Asian Miracle: Economic Growth and Public Policy. New York: Oxford University Press.

_. 1993b. Guyana: Private Sector Development. Washington: World Bank.

1994a. Jordan: Consolidating Economic Adjustment and Establishing the Base for Sustainable Growth. Report 12645 JO. Washington: World Bank. 
1994b. Trends in Developing Economies, 1994. Washington: World Bank.

1994c. World Debt Tables, vol. 2, External Finance for Developing Countries. Washington: World Bank.

1994d. World Tables, 1994. Baltimore: Johns Hopkins University Press.

Wright, John W., editor. 1993. The Universal Almanac, 1994. Kansas City: Andrews and McMeel.

Yamamura, Kōzō. 1982. Policy and Trade Issues of the Japanese Economy: American and Japanese Perspectives. Seattle: University of Washington Press.

Yeager, Leland B. 1976. International Monetary Relations: Theory, History, and Policy, second ed. New York: Harper \& Row.

Young, Alwyn. 1991. "Learning by Doing and the Dynamic Effects of International Trade." Quarterly Journal of Economics 106(2): 369-405. 